ECONOMIC COMMISSION FOR LATIN AMERICA AND THE CARIBBEAN

\title{
PRELIMINARY OVERVIEW OF THE ECONOMY OF LATIN AMERICA AND THE CARIBBEAN \\ 1992
}

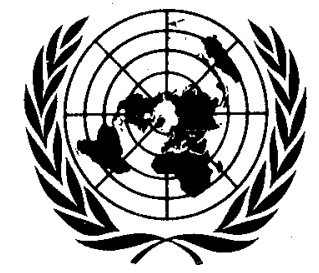

UNITED NATIONS 


\section{UNITED NATIONS}

\author{
ECONOMIC COMMISSION \\ FOR LATIN AMERICA AND \\ THE CARIBBEAN - ECLAC
}

Distr.

GENERAL

LC/G.1751

18 December 1992

ENGLISH

ORIGINAL: ESPAÑOL

\section{PRELIMINARY OVERVIEW OF THE LATIN AMERICAN AND CARIBBEAN ECONOMY 1992}

\section{GENERAL OVERVIEW}

In 1992 the economic situation in Latin America and the Caribbean was similar to that of 1991: economic expansion that exceeded population growth, together with lower inflation. However, there is now a wider divergence among the performances of the various economies. In this regard the performance of Brazil with an economy that has a very large weight in regional averages contrasts with that of most of the other countries in the region.

This year a growing number of countries progressed in consolidating their adjustment processes. However, the persistent sluggishness of world trade and the apparent slowdown of capital inflows in the second half of the year raise some questions that were not present when the year began.

Preliminary estimates indicate that the gross domestic product of the region as a whole grew by $2.4 \%$ (compared to $3.5 \%$ in 1991). Excluding Brazil, the output of the rest of the economies of Latin America and the Caribbean increased by $4.3 \%$ (compared to nearly $5 \%$ in 1991). Accordingly, if Brazil is excluded, regional per capita GDP rose by $0.5 \%$, or nearly $2.3 \%$ in 1992 .

At the same time, the pronounced downward trend in the rate of inflation continued: only five countries experienced significant increases compared to 1991, and only one (Brazil) had inflation of over three digits. On the other hand, many countries tended to approach inflation rates that were only slightly higher than the evolution in international prices.
In view of the international backdrop of widespread recession and uncertainty, this growth, which took place in a context of increasingly stable prices, was a considerable achievement. The sluggishness of world trade in 1992 was reflected in a steady worsening of the terms of trade in goods in almost all the countries, with Argentina being the sole exception. The Central American countries were particularly affected by this deterioration. On the other hand, a considerable number of countries notably Brazil, Chile, Costa Rica and Honduras expanded the volume of their exports.

The vigorous expansion of imports observed the preceding year continued and in some cases even accelerated in 1992 stimulated by tariff liberalization and appreciation of local currencies. This induced a negative merchandise trade balance for the first time in many years. Hence the current-account deficit of the balance of payments also widened considerably.

What sustained this trend, and at the same time contributed to stabilization efforts, was a considerable net inflow of financial resources for the second year in a row; indeed, this inflow, amounting to over US $\$ 57$ billion in 1992 was perhaps the most prominent feature of the regional economic picture over the past two years.

This inflow of capital was a result, inter alia, of widening differentials between the real interest rates offered in Latin American markets and those prevailing in the United States, and extraordinary rates of return derived from the economic recovery and privatization processes. Another contributing factor was the expectation of more stability of permanency regarding the economic policies prevailing in the region.

The net inflow of capital was used to finance imports, investments and speculative operations; it also helped to close fiscal gaps (through the acquisition of government bonds and privatized public enterprises), spurred a non-inflationary expansion of credit to the private sector (for both investment and consumption) and shored up the region's international reserves.

As noted above, this sudden easing of external constraints contributed to economic expansion, without undermining stabilization efforts. Net capital inflows more than offset the negative effects of the deterioration of the terms of trade. On the domestic front, these resources were quickly channelled to provide a stimulus to private-sector demand. In a few countries, however, capital inflows induced an appreciation of local currencies, and occasionally made monetary policy more difficult. Moreover, when short-term capital constituted a large proportion of these inflows, a potential element of volatility was introduced into the economic situation.

The appreciation of local currencies held down the prices of tradeable goods; however, this was generally not true to the same extent for the costs of private services. Increases in public service rates, associated with fiscal adjustment or privatization, also helped to raise the relative prices of non-tradeables. Overall, the changes in relative prices acted as an incentive to allocate resources towards 
non-tradeable goods and away from export-oriented sectors.

The drastic fiscal adjustments of the past three years were sustained, or even tightened, in most of the countries. Naturally, these policies have contributed to stabilization processes, both directly, through their effect on monetary expansion, and indirectly, by bolstering the confidence of private agents regarding the permanence of economic policy.

In most cases, the interest burden on fiscal budgets was stabilized, although in proportions that ranged from $1 \%$ to $4 \%$ of GDP, depending on the case. Contributing factors include negotiations to regularize external debt servicing; the decline in international interest rates; and the fiscal adjustment itself, which, in the context of monetary discipline, drastically relieved the need to resort to domestic indebtedness and restricted the possibilities of doing so.

In only a few countries, however, can the fiscal accounts be said to be structurally balanced. For this to be the case, current income must be solidly backed by a stable tax base, which in turn is consistent with a level of current spending that can support the normal functioning of government administration and the provision of basic social services. The tax base must also be able to support the public investment required to revamp and develop infrastructure necessary for economic growth and enhanced social equity.

All the above-described phenomena were backed by institutional reforms aimed at reinforcing export-oriented growth and trade liberalization, deregulation of the price system, consolidation of fiscal equilibria and more prudent management of monetary policy. In most countries, however, these reforms have not yet managed to recoup the losses derived from the accumulated social setbacks of earlier years.

The apparent slowdown in capital inflows at mid-year, coupled with a continued sluggish world economy, raised some concern towards year-end. This was manifested in the more cautious expectations of economic agents, in the behaviour of stock markets and in less degrees of freedom for the region's economic management which has the objective of sustaining growing rates of economic expansion over time in a context of progressive financial stability.

After long years of efforts to diversify their export structure, it is of cardinal importance for Latin America and the Caribbean that favourable external conditions now exist for an ordered expansion of world trade, both with respect to macroeconomic management in the major developed economies and the institutional arrangements that will govern the exchange of goods and services. At the same time, intraregional trade should be encouraged under the reciprocal agreements that have been multiplying in recent years.

That the region has become a net importer of financial resources is without doubt a positive sign, and achievements in this area should be sustained and consolidated. It is necessary that external capital flows not only maintain continuity in terms of their global dimension, but also constitute stable financing of productive investment.

This in turn requires finding a more appropriate mix of funding, with increased participation of banking capital, more flows from multilateral agencies and an enhanced proportion of institutional portfolio investment, while at the same time attempting to avoid an excess build-up of short-term capital, which could become a source of volatility. On the part of the recipient countries, it is necessary to expand emerging domestic capital markets and strengthen the regulatory framework of financial systems. A particularly important role must also be played by fiscal policy with regard to the maintenance of an appropriate and flexible balance: on the one hand, to prevent uncertainty in the minds of private agents about the stability of domestic policy, avoiding sudden pressures on the financial system and, on the other, to allow more degrees of freedom for monetary and exchange rate policy.

\section{THE ECONOMIC ENVIRONMENT}

\section{SUMMARY}

Preliminary ECLAC estimates indicate that the gross domestic product of the region as a whole increased by $2.4 \%$ in 1992 , thus gradually continuating the recovery already in evidence the previous year, when output expanded by $3.5 \%$. Meanwhile, per capita GDP registered a slight increase of $0.5 \%$.

The moderate rise in the region's level of economic activity was strongly determined by the deepening recession in Brazil. Excluding Brazil, the output of the other economies of Latin America and the Caribbean, grew by $4.3 \%$, compared to nearly $5 \%$ the previous year and about $3 \%$ in 1990.

A significant number of countries registered notable growth rates, although their economies are at different conjunctural stages. Chile's economic growth stands out at $9.5 \%$, in its fourth year of expansion as part of a long-term growth path and in its second year after a 1990 adjustment desianed to quash incipient inflationary pressures. Five countries registered growth rates of between $6 \%$ and $8 \%$ : Argentina's economy has been recovering since 1991, under the influence of stabilization inflows of external capital; Panama, in its third year of growth, has emerged from the crisis of 1988-1989; despite a tight fiscal policy, Uruguay has begun growing again after its virtual stagnation of recent years, thanks in part to the recovery of neighbouring Argentina; Venezuela is still expanding rapidly, fueled by a growing fiscal deficit; and the Dominican Republic's economy has begun a strong recovery.

Another group of countries grew at rates of between $3 \%$ and $5 \%$, in most cases higher than those of 1991, either because their growth rates have revived (Colombia, Costa Rica, El Salvador and Guatemala), or because they have consolidated their recovery (Honduras and Guyana). Bolivia and Ecuador, however, recorded a slight slowdown in their earlier rate of expansion. Mexico's economy, where output rose by $2.5 \%$, recorded a moderate but sustained deceleration of its growth rate.

Paraguay, where output increased by only $1.5 \%$, continued a three-year relapse from its formerly vigorous growth pattern. Jamaica's growth rate also decelerated. Nicaragua, whose output increased slightly, and Peru, whose level of economic activity fell by $2.5 \%$, continued to undergo deep recessions for the fifth year running, despite their notable achievements in price stabilization.

Brazil's output declined by $1.5 \%$, after a modest, temporary recovery in 1991, thus prolonging the predominantly recessive pattern registered since 1988, in a context of persistently high inflation.

Haiti's chronic recession also worsened, with a drop of $5 \%$ in its GDP. For the third year in a row, Barbados recorded a $2.5 \%$ decline in its economic activity. In Cuba, the economic recession seriously deepened as a result of the complete elimination of its formerly beneficial trade relations with the countries of eastern Europe and the former Soviet Union, compounded by the tightening of the United States' economic blockade.

Price stabilization advanced and strengthened in the greater part of the region. Only Brazil, Ecuador, El Salvador, Haiti, Paraguay and Trinidad and Tobago saw a significant upsurge in their inflation rates. Excepting Brazil whose inflation rate 
causes the region's weighted average rate to more than double, the increase in consumer prices in the remaining countries fell from $49 \%$ in 1991 to $22 \%$ in 1992 . Further, for the first time in years, most of the countries had annual inflation rates of less than $20 \%$.

High-inflation economies that only two years ago were caught up in hyperinflationary spirals became more stable. Following a rapid deflationary process, in 1992 Argentina and Nicaragua stabilized their annual rates of growth of consumer prices at less than $18 \%$ and $2 \%$, respectively. Peru, which had also somewhat retreated from hyperinflation in 1991, managed to limit the rate of price rises to less than $60 \%$ per year, and Uruguay also reduced its high rate of inflation to less than $60 \%$. The situation in Brazil stands in contrast to these advances: there, inflation soared to an annual rate of almost $1,200 \%$.

A good number of countries with moderate inflation rates kept inflationary pressures down for the second year running. Bolivia reduced its annualized price variation from $15 \%$ in December 1991 to $11 \%$ in October; Costa Rica, from $25 \%$ to $18 \%$; Chile and Mexico, from $19 \%$ to $14 \%$ and $13 \%$, respectively, in November; Honduras, from $21 \%$ to slightly over $5 \%$ in October. The Dominican Republic also held its annual inflation rate down, to below $6 \%$. Jamaica managed to reduce its annualized price variation from $77 \%$ to $14 \%$ in September.

Other countries, however, have run into stumbling-blocks in their efforts to hold down inflation. In Colombia, the inflation rate was only reduced from $27 \%$ to $26 \%$ in November. In Guatemala, it rose from $10 \%$ to $12 \%$ in October. Fiscal and exchange measures taken in Ecuador in the second half of the year pushed the annual inflation rate up from $49 \%$ to $66 \%$ in October. In Paraguay, inflation also took a turn for the worse, rising from $12 \%$ to $17 \%$ annually in November. The same occurred in $\mathrm{El}$ Salvador, from an annualized $10 \%$ to $17 \%$ in October. In Venezuela, the annual price increase rose from $31 \%$ to $33 \%$ in October, even though the updating of public service rates was slow in taking effect.

In brief, a large number of countries of the region are registering continued growth at least for the third year in a row with relative price stability and satisfactory degrees of utilization of their productive capacity. Of those that have been in this situation for a number of years, Chile continues to grow at a high rate, boosted by its export strategy. Colombia and Costa Rica, on the other hand, are recovering after a downturn in 1991 , and Paraguay is still witnessing a slowdown in its formerly vigorous rate of expansion. Other countries, which completed their recovery more recently (such as Bolivia, El Salvador, Guatemala, Mexico and Panama), also recorded continued growth with relative price stability.

Meanwhile, Ecuador, Uruguay and Venezuela are just now achieving full utilization of their productive capacity, through more rapid rates of expansion, at least in the last two cases. However, although their stabilization trends differ, they have all been operating under regimes of controlled price instability. Ecuador has put into effect a severe adjustment and stabilization programme in recent months; Uruguay has continued to reduce its high inflation rate significantly; Venezuela, on the other hand, still has a high inflation rate, together with a widening fiscal deficit.

The economies of Argentina and Honduras have also further consolidated their recovery, while the Dominican Republic has vigorously launched its own recovery programme. In the first two cases, the process of rapid stabilization resulted in a prolonged relative price stability. In the Dominican Republic, the stabilization process has recently been completed. Nicaragua and Peru have achieved relative price stability. However, for the fifth consecutive year, these two economies are suffering from a deep recession with sizeable margins of idle capacity.

For its part, Brazil has been in a recessionary situation for five years running (within which it has had temporary, brief recoveries in its level of economic activity) and it continues to operate in a regime of high-inflation.

The year 1992 saw a new, more wide-ranging expansion of Latin America and the Caribbean's import capacity. This was due to the rise in net capital inflows, since the region's increase in the value of exports was modest and net payments of profits and interest were reduced only marginally. This situation, coupled with in many cases appreciating local currencies and an upholding or deepening of import liberalization, made it possible to continue the general boom in imports throughout the region.

Thus; the region's formerly ample trade surplus turned into a deficit. Furthermore, only a small number of countries among which Brazil stands out due to the sheer size of its surplus have maintained a positive merchandise trade balance. Brazil's exports to Argentina under prevailing free trade agreements has been a strong factor in the increase of the former's surplus.
The terms of trade of the region underwent a new decline in 1992, this time amounting to more than $3 \%$, thus accentuating the almost steady deterioration observed since 1984, which represents $22 \%$ in cumulative terms. This year the downturn affected both oil-exporting and other countries. Accordingly, the purchasing power of the region's merchandise exports expanded by only $3 \%$, despite the significant increase in their volume.

The value of merchandise exports from Latin America and the Caribbean continued to climb slowly, this time by $4 \%$, reaching US $\$ 126$ billion. The sluggish growth stemmed from the slump in unit values, since export volumes rose by $6 \%$. Even so only half the countries of the region managed to augment their exports at a higher rate than that of world trade in general.

The value of exports from oil-exporting countries contracted slightly, owing to the decline in unit values, which some countries of this group were able to partially offset by increasing volumes. However, the somewhat more abundant capital inflows maintained the oil-exporting countries' capacity to import and permitted reserve accumulation.

The non-oil-exporting countries of South America raised the value of their exports: those of Brazil and Chile increased considerably in value, by about $12 \%$. Combined with the upsurge in net capital inflows to Brazil, Argentina and, to a lesser extent, Chile, this rise in export values represented a considerable expansion of the group's import capacity. Of the Central American and Caribbean countries, Costa Rica, Guatemala and Honduras significantly expanded the value of their exports, despite the slight deterioration in unit values. Conversely, lower prices resulted in lower total values in the other countries of the group.

The value of Latin America and the Caribbean's merchandise imports rose to US\$132 billion, again representing an increase of $18 \%$ and prolonging a sharp expansion for the third year running. This growth was even more widespread than in 1991, although the variation in the regional total was strongly influenced by the import expansion of Mexico (US\$8 billion), Argentina (US\$5.7 billion), Venezuela (US $\$ 2.6$ billion) and Chile (US\$1.8 billion).

The merchandise trade balance, which had been positive by US $\$ 10$ billion in 1991, turned into a deficit of nearly US\$6 billion. At the same time, net non-factor service payments continued to expand, rising to US\$4.9 billion. 
Net payments of profits and interest continued to diminish, this time to US\$29.6 billion. This was mainly due to the decline in international interest rates, the effect of which was partly offset by higher remittances of profits.

The balance-of-payments deficit on current account widened once again in 1992, this time to nearly US\$33 billion, owing to the deterioration of the trade balance.

The bigger current-account deficit was easily financed through the net flow of US\$57 billion of capital into the region, which greatly surpassed the US\$39 billion inflow in 1991. Although the increase in capital inflows was fairly widespread, the net rise (of US\$18 billion) in the regional total was accounted for by only a few countries. The first of these was Brazil, which registered US\$10 billion in net capital inflows, compared to only a little more than US $\$ 1$ billion the year before. Argentina also experienced a sizeable increase (US\$4 billion) in the net inflow of capital, which totalled US $\$ 9.3$ billion in 1992. Capital inflows into Mexico exceeded US\$23 billion, or US\$1.8 billion more than in 1991 . The increases in Venezuela (US\$1.5 billion) and Chile (US\$1.3 billion) accounted for a good proportion of the additional capital flows into the region.

Capital entering the region in 1992 was still essentially from private, non-banking sources and consisted of various types of investments. The most important flows consisted of financial placements and short-term credits. The acquisition of stocks also represented a large proportion, mainly in Mexico, although they were significant in Argentina, Brazil and Venezuela as well. Foreign direct investment increased considerably, mainly in Mexico and, to a lesser extent, in Brazil, Argentina, Chile and Venezuela. These countries also placed abroad large amounts of either government or private sector bonds.

As the net capital inflow was far greater than the current-account deficit, the international reserves of most countries of the region continued to increase for the fourth year in a row. However, more than half the rise in the regional aggregate total corresponds to Brazil, whose reserves expanded by more than US $\$ 16$ billion.

The greater amount of net capital flows, under circumstances where payments of profits and interest were on the decline, meant that the net transfer of financial resources to the regiorı rose from US $\$ 8$ billion to US\$27 billion, a figure that had just become positive after a decade of negative balances in 1991. Most of this expansion was due to the fact that in 1992 Brazil, Argentina and Chile converted their formerly negative net transfers to largely positive ones.

The region's external debt registered an increase of $2 \%$, climbing to over US\$450 billion. This expansion was partly due to new bond placements abroad, disbursements of official loans, an increase in short-term credit operations and an accumulation of arrears in some countries. Other factors, however, helped to shrink the debt, such as the recent recovery of the dollar against other currencies, which reduced the dollar value of the debt denominated in these other currencies, and the various debt-reduction mechanisms used in many countries of the region.

In 1992 the indicators of the region's external debt burden continued to abate, strengthening the downward trend observed in recent years. The coefficient representing interest owed as a percentage of exports dropped for the sixth year running, this time to $20 \%$, the lowest figure since 1980 . This decline was mainly due to the reduction of gross interest payments. For the region as a whole, the debt-export ratio decreased slightly, to below $290 \%$, owing to the improvement of this ratio in the non-oil-exporting countries. None the less, in 1992 only five countries had a coefficient lower than the critical threshold of $200 \%$.

\section{MAIN TRENDS}

\section{Economic activity}

The level of activity in Latin America and the Caribbean grew by $2.4 \%$ in 1992 . Thus the recovery which had begun last year when growth was $3.5 \%$ continued, albeit at a slower pace. Per capita output in 1992 again posted a slight positive increase $(0.5 \%)$. Nevertheless, regional output was only $19 \%$ higher than it had been in 1980 , before the debt crisis erupted, while per capita output was $7 \%$ below what it had been in 1980 and equivalent to a level already recorded in 1978.

The slow growth in regional output has been caused largely by the worsening recession in Brazil. Excluding Brazil, the increase in the output of the other countries was $4.3 \%$, somewhat less than this same group of countries had registered in 1991 $(5 \%)$, but otherwise the highest figure since 1981.

The growth in output was a fairly general phenomenon, although there were wide divergences. In Chile, the increase was $9.5 \%$, the second highest in the past two decades, continuing its steady expansion for the ninth consecutive year, and outstripping the 1980 level by more than $50 \%$. In Argentina, the Dominican
Republic, Panama, Uruguay and Venezuela, the level of activity was up by between $6 \%$ and $8 \%$. Also, in four countries Costa Rica, El Salvador, Guatemala and Honduras output grew between $4 \%$ and $5 \%$; in five Bolivia, Colombia, Ecuador, Guyana and Mexico it grew around 3\%; in three others the Bahamas, Jamaica and Paraguay between $1 \%$ and $2 \%$. In three Nicaragua, Trinidad and Tobago and Suriname it remained unchanged and in four Barbados, Brazil, Haiti and Peru it fell. Eight countries fared better than they had in 1991, while in seven others, the growth rate remained at its 1991 level or rose somewhat more slowly; in nine others, the level of activity deteriorated or remained modest. In turn, the smaller countries of the Organization of Eastern Caribbean States (OECS) maintained their growth rate of previous years, posting an average increase of around $4 \%$, which was higher than the 1991 rate (see table 2).

Despite the high rates of population growth in many countries in the region, the results in terms of per capita output were mainly positive. In six countries Argentina, Chile, the Dominican Republic, Panama, Uruguay and Venezuela this indicator of well-being went up by more than $3 \%$, while in eight others, the increase was moderate, between $1 \%$ and $3 \%$. Meanwhile, in the other 11 countries, per capita output increased slightly or fell. However, considering the poor performance of the region's economies in the past decade, per capita output was higher than the 1980 figure in only a few countries: Chile (25\%), Colombia (20\%), Bahamas (17\%), Jamaica $(7 \%)$, Uruguay $(3 \%)$ and the whole group of OECS countries $(72 \%)$. At the other extreme, the most severe reductions in per capita output occurred in Nicaragua $(-39 \%)$, Peru (-32\%), Trinidad and Tobago $(-30 \%)$, Haiti $(-28 \%)$, Guyana $(-23 \%)$, Bolivia $(-21 \%)$, Suriname $(-19 \%)$, Guatemala $(-17 \%)$, Argentina $(-11 \%)$ and El Salvador and Honduras $(-10 \%)$ (see table 3).

There were few changes of any significance in unemployment rates compared to previous years, as most economies of the region experienced moderate growth. The drop in unemployment was noteworthy only in those economies where the level of activity had increased sharply, such as Chile, Panama and Venezuela. In Argentina and Uruguay, on the other hand, the jobless rate rose slightly, despite the significant increase in the level of activity. In Colombia, the unemployment rate rose by one half of a percentage point, moving to $10.5 \%$. Brazil also registered higher unemployment, for the third consecutive year, owing to the acute recession in which it has been trapped for several years. 
Chile again posted a high rate of growth $(9.5 \%)$, a sign that it is passing through an unprecedented period. Per capita output was thus $25 \%$ higher than it had been in 1980. The vigorous expansion of 1992 was based on a $20 \%$ increase in investment, a $15 \%$ increase in the physical volume of exports, and a more rapid rise in consumption. The increase in expenditure occurred mainly in the private sector; whereas public expenditure rose by $5 \%$ in the first half of the year, the increase in private expenditure was $14 \%$. With the acceleration of growth in the third quarter, this difference between the expansion of the public and private sectors was even more marked. The growth was attributable chiefly to the structural improvement in the balance-of-payments position. The situation in Chile was characterized by a large trade surplus, steadily rising foreign investment, a virtual return to the voluntary external credit market, net reserves equal to more than one year's imports, the maintenance of fiscal discipline and a marked decline in the relative external debt burden. This spectacular expansion, however, aroused concern about a possible overheating of the economy and growing difficulties in further developing the export strategy. In order to avoid overexpansion of domestic demand, interest rates on Central Bank financial instruments were increased three times during the year. The dynamic economic situation was also reflected itself in higher employment and a drop in open unemployment of more than two percentage points to $5 \%$, the lowest level in more than a decade.

In Venezuela, the rapid recovery of the level of activity continued following the 1989 recession. In fact, output rose slightly more than $8 \%$, lagging somewhat behind the 1991 figure, but still extremely high compared to past averages. This expansion was confined solely to private activities, for the petroleum sector declined by nearly $2 \%$ and the public sector registered modest growth. Particularly noteworthy was the boom in the trade sector, which climbed by $24 \%$, more than twice as much as it had in 1991, stimulated by increased domestic demand and by imports as a result of an appreciating local currency and trade liberalization. Construction, for its part, continued to expand significantly (18\%), even though it trailed the 1991 rate of $31 \%$. In 1992, the sector owed its dynamism much more to the implementation of private projects than to the petroleum industry, which had been responsible for the sharp increase in 1991. The manufacturing industry also grew significantly $(10 \%)$, despite the adverse effect of the foreign exchange policy. The agricultural sector continued its recovery (3.5\%) begun in 1991, in response to the partial elimination of subsidies and price controls. The output of the petroleum sector declined when the international hydrocarbons market returned to normalcy after the Gulf conflict and OPEC production quotas were lowered as a result. The urban unemployment rate went down from $9.6 \%$ in 1991 to $7.7 \%$ in the third quarter of 1992 as a result of significant growth, particularly in construction.

In Uruguay, gross domestic product rose by $7 \%$ in 1992 , the highest rate in the past five years. This litted per capita output to an all-time high, even slightly higher than the figure for the 1980-1981 biennium, mainly as a result of the demand in Argentina and the value-added earned on a huge import volume. The electricity, gas and water sector rose by $25 \%$ because of increased domestic demand and, in particular, because of substantially higher sales to Argentina. Business activity in the commerce, restaurants and hotels sector rose by $16 \%$, owing essentially to the selling, by middlemen, of imported goods and to tourist flows, mainly from Argentina. The agricultural sector increased its output by $9 \%$ as a result of the recovery of crops from the poor weather conditions of 1991, increased cattle-raising activity and the replenishment of livestock. The other goods-producing sectors also expanded, with the sole exception of fisheries, at rates that ranged from slightly more than $2 \%$ in the manufacturing industry to slightly less than $6 \%$ in construction. In other services, the increase was almost $7 \%$. Despite this significant growth, the urban unemployment rate crept up, hitting $9.3 \%$.

The level of activity in Argentina again bounced back $(6 \%)$, in a macroeconomic context that was clearly more stable than it had been in the recent past. Thus, the level of the gross domestic product was higher than it had been before the crisis of the early 1980s. Domestic demand continued to be way up, among both consumers and investors, although investment was still nowhere near its record highs. The counterpart of this increased demand was a surge in imports and a sharp increase in domestic output as well. With the exception of certain activities, such as iron and steel, which are more dependent than others on external markets, the manufacturing industry expanded considerably more than $10 \%$. This was very obvious, for example, in certain metalmanufactures sectors. In taking the average for the year, however, the effects of macroeconomic normalcy and the expansion of credit which had sparked the intense recovery seemed to lose momentum. There were signs that the growth of domestic expenditure was reaching its limit, while exports were weak, and this somewhat moderated the demand for industrial products. In any case, an overview of the whole year indicates that output stretched to meet the greater demand for manufactured goods, with only slightly higher prices. The increase in activity apparently gave rise to an increase in employment, but since the labour supply increased as well, the unemployment rate topped that of the previous year.

In 1992, growth slowed down in Mexico $(2.5 \%)$. Although investment remained high, it was not sufficient to offset the disincentives of lower external demand, a progressively restrictive monetary policy and the intense adjustment process of the productive apparatus linked to trade liberalization. Compounding the problem were adverse weather conditions, which were responsible for the poor performance in the agricultural sector. For the fourth consecutive year, growth in output outstripped population growth. There was a major expansion of construction $(8 \%)$ and of electricity, gas and water services (4\%). In manufacturing activity, on the other hand, external and domestic demand fell and imports crowded out national production, compressing the rate of growth to slightly more than $2 \%$, down from nearly $4 \%$ in 1991 . The growth rate in services, in turn, decreased, with the exception of transport, storage and communications. There were also severe job cutbacks in the manufacturing industry. On the other hand, the number of persons employed in construction, commercial activities, especially in the larger firms and the inbond assembly industry increased. Also, until September, the number of permanently employed workers contributing to the Mexican Social Security System had risen by $2.8 \%$, compared to a $7.3 \%$ increase over the same period in 1991. On the other hand, employment in the informal sector of the economy continued to rise.

In Colombia, output grew by $3 \%$, one point higher than the year before, despite the effects of poor weather conditions in the first part of the year. The healthiest sectors were mining, which increased by more than $11 \%$, construction (10\%) with housing well in the lead, and coffee threshing, which grew by $15 \%$. The growth rate was low less than $2 \%$ elsewhere in the manufacturing industry. The performance of the agricultural sector was also poor because of the severe drought caused by "EI Niño"; its growth was on the order of $1 \%$, whereas the average of the preceding three years had been higher than $5 \%$. The drought not only reduced harvests, but also substantially depleted the water supply in reservoirs, which made strict electrical power rationing necessary throughout the country. Services, for their part, expanded moderately, at a slower rate than total output. Domestic demand grew by $4 \%$ but it was partly diverted towards imports, 
which grew by $20 \%$, while the volume of exports declined slightly. Private investment rose dramatically $(8 \%)$, while public investment grew by over $5 \%$. Urban unemployment increased moderately, moving up to $10.5 \%$.

The gross domestic product of Ecuador continued to rise in 1992 (3.5\%), somewhat less than its 1991 level. The main impetus came from the petroleum sector and agricultural products for domestic consumption, and the rapid increase in private investment. Public-sector capital expenditure, for its part, remained unchanged, as a result of the adjustment policies implemented when the new Government took office in August. Oil drilling increased by $5.5 \%$ with the exploitation of new oilfields. As a result of this expansion, Ecuador exceeded the OPEC quota, which was doubtless one of the main reasons for its withdrawal from that organization. The agricultural, forestry, hunting and fishing sector grew by slightly more than $6 \%$ overall, similar to the previous year's increase, though growth was uneven within the different subsectors. In 1992, the production of bananas, coffee and cocoa, which had been the strong players in recent years fell significantly. Fishing again showed a noteworthy rise $(12 \%)$, although not as much as it had the year before. On the other hand, the increase in output was greater in sectors producing for the domestic market. The manufacturing industry continued the recovery it had begun in 1991, with growth in the vicinity of $5 \%$. Construction edged up (less than 1\%) after a two-year recession. Meanwhile, the electricity, gas and water sector went down by $7 \%$, owing to weather problems at the beginning of the year.

In Bolivia, the growth rate (3.5\%) fell only slightly and per capita output increased for the sixth consecutive year. Greater domestic demand gave rise to an expansion of activity, both because of greater consumption and the momentum gained by investment, which soared to an unprecedented rate of $24 \%$ of GDP, reflecting an expansion in both public and private investment. Private investment was channelled essentially into mining and the hydrocarbons sector. There was a $5 \%$ increase in industrial production, stimulated by the drop in interest rates and increased consumption. Both the mining and construction sectors rose by nearly $4 \%$. Agriculture, meanwhile, remained unchanged.

In Paraguay, the level of activity slowed down in 1992 for the fourth consecutive year $(1.5 \%)$, and, as a result, per capita output, which had already fallen in 1991, remained on the decline. This poor performance was caused chiefly by the drop of more than $7 \%$ in agricultural production, affected by the lack of rainfall at the beginning of the year and flooding in May, not to mention the lack of credit and the depressed international prices of the main export items. Harvests of the main crops were smaller: cotton $(-47 \%)$, soybeans $(-15 \%)$, tobacco $(-32 \%)$, beans $(-7 \%)$ and rice $(-5 \%)$. In turn, sugar cane and cassava production held steady, while maize production increased by $9 \%$. This decline in the agricultural subsector was partly offset by higher fishery and forestry production. Industrial output grew by somewhat less than $1 \%$, while the rate of construction activity increased (3.5\%), spurred by the continuation of low-income housing projects, some infrastructure works in the public sector and the construction of private homes. The services sectors, for their part, registered overall growth of nearly $2 \%$.

The economy of Brazll remained in a recession, with a dip of $1.5 \%$ in the level of activity amid stubborn inflation at a monthly rate of over $20 \%$ and major political changes throughout the second half of the year. Thus, per capita output fell by $3 \%$, down $9 \%$ from its 1980 level. After a year of extreme sluggishness in 1990 and a modest, temporary upsurge in 1991, the level of activity again began to grow in the first half of 1992, bolstered by abundant harvests and the boom in the export of manufactured goods. In the second half of the year, the upward trend petered out and Brazil entered another period of recession, the fourth in less than three years, largely as a consequence of the political crisis that broke out in June. The vigour of domestic demand in the first half of the year began to flag in September. It had been stimulated by the continued increase in liquidity resulting from the monthly release of frozen financial assets. When the release of assets stopped in August, so did the stimulus, and recessionary trends resurfaced, these, in turn, were aggravated by high real interest rates and the curb on external capital inflows. The manufacturing industry took a plunge $(6 \%)$ owing to the sharp decline in domestic demand, which could be only partly offset by the $19 \%$ rise in the export of manufactured goods. There was also a steep decline in construction, following a turn for the worse in investment. The commerce sector followed suit, going down by $5 \%$. The agricultural sector, on the other hand, registered an increase of $6 \%$, as a result of the bountiful harvests in the first months of the year. The recession chiefly affected the urban sector, where the unemployment rate rose by more than a percentage point to nearly $6 \%$ of the workforce. Similarly, formal urban employment virtually held steady. In industrial activity, companies reacted to the recession by cutting back so many jobs that in the State of São Paulo, the employment figure in October 1992 was not even 90\% of what it had been in 1978 .

In Peru, after a timid rebound in 1991, the gross domestic product again dipped $(-2.5 \%)$, completing five years of severe economic recession and representing an accumulated decline of $24 \%$ in the level of activity. Production was again hurt by tighter credit, and, beyond that, by bankruptcies in the financial system and inordinately high interest rates. Moreover, the climatic phenomenon known as "El Niño" decreased the anchovy catch and caused a drought that seriously affected agriculture and the generation of electrical power; this, in turn, affected manufacturing output. Mining, for its part, posted a decline on the order of $2 \%$.

The members of the Central American Common Market registered overall growth of nearly $4 \%$, the largest increase since the crisis of the early 1980s. Furthermore, the expansion was fairly evenly distributed, for, with the exception of Nicaragua, which remained in a deep recession, the other countries posted growth rates of around $4 \%$. Costa Rica registered growth of $4 \%$, compared to a modest increment the year before, because of the turnaround In industrial activity, a very dynamic services sector and the significant expansion of the external sector. The most active areas were the service related sectors such as trade, transport, storage, communications and finance. Manufacturing, after a somewhat sluggish phase in 1991, rebounded considerably (5\%). Construction, however, continued to decline, as it had in 1990 and 1991. Agricultural production rose by only $2 \%$, compared to nearly $6 \%$ the year before, largely as a result of the drop in international coffee prices and lower production of basic grains for domestic consumption. Banana production, for its part, continued its upward trend of recent years, owing to the yield from new plantations and the fact that international prices were still relatively high. Fishing declined, mainly because of the drought in various parts of the country.

In El Salvador, the increase in gross domestic product was fairly high (4.5\%), although some momentum was lost at the close of the first half of the year because of serious problems with electrical power supply. Investment was the most dynamic area of aggregate demand; private investment was channelled into construction, particularly the expansion of large businesses. Public investment, for its part, posted a very healthy increase $(40 \%)$, as a result of larger infrastructure works in social services and the restoration of electrical power generation capacity. Private consumption benefited in part from the consolidation of the economic recovery 
and more remittances from Salvadorans who had emigrated to other countries. In a repeat performance of what had taken place in the previous year, construction was the most dynamic sector, while the agricultural sector recovered from a poor season the year before and the manufacturing industry managed to sustain the growth rate begun in the second half of 1991. A shortage of water in the country's hydroelectric dams brought electricity production way down in the second quarter, making it necessary to reinstate a rationing programme; later, however, the situation improved markedly.

The gross domestic product of Guatemala rose by more than $4 \%$, the highest rate in the past seven years, and per capita GDP again increased for the sixth straight year. Once again, investment was the most vigorous component of aggregate demand, reaching $9 \%$ as a result of private investment, in as much as the increase in public investment was moderate. The rise in consumption was the highest in the past four years, driven by the increase in both public-sector and private-sector wages. For the second consecutive year, construction registered the greatest expansion. The increase in agricultural output went down to slightly less than $3 \%$, owing in part to the drop in the prices of export/commodities and the delayed effect of last year's drought on basic grain production. Industrial output posted a growth rate of nearly $3 \%$, higher than the figure for 1991, as result of the recovery of real wages, the decrease in the interest rate and the dynamic growth of exports to the Central American Common Market. The inbond assembly industry, which had been a major source of foreign currency and jobs, in the past five years, remained unchanged.

Growth in output in Honduras (4.5\%) was more than two percentage points higher than it had been the year before, and per capita GDP improved by more than $1 \%$. The driving force behind demand was exports, whose volume swelled by $20 \%$. Domestic demand, by contrast, after recovering in 1991, registered a slower rate of growth, for while consumption had increased, its effect was cancelled out by the sluggishness of private investment. Public investment, for its part, again increased $(18 \%)$, albeit at a slower rate than in 1991. In a sectoral breakdown of output, most branches of activity demonstrated positive growth, and construction soared. Only public administration, defence and social, community and personal services continued their downward trend of the past two years. Meanwhile the agricultural sector, slowed down; although all its subsectors advanced, they did so more gradually than in 1991. Even forestry, after many years of decline, managed to reverse that trend.

The gross domestic product of Nicaragua rose by only $0.5 \%$, which further pushed down per capita output by more than $3 \%$. This means that there have been nine years of uninterrupted decline in per capita GDP, by a cumulative total of $43 \%$. Plummeting export prices, the particularly difficult cotton situation, the series of natural disasters, outside events that had nothing to do with the economy, and the priority accorded to fiscal discipline as a key element in price stability brought on an economic slump. The agricultural sector rebounded, despite a series of setbacks, particularly in cotton, as a result of higher yields in maize, beans, rice, beef and poultry breeding, while fishing declined following the tidal wave. The manufacturing industry declined by nearly $2 \%$ after experiencing exceptional growth in 1991. Electrical power generation, on the other hand, rebounded, especially thermal energy, which minimized disruptions in service. Construction was also very vigorous (13\%), owing to maintenance programmes, reconstruction projects and efforts to bring down a tremendous housing deficit. Sluggish economic activity pushed up open unemployment, from $14 \%$ to over $16 \%$.

In Panama, gross domestic product rose by $7.5 \%$, slightly trailing the rate for the previous year. The most dynamic sector continued to be construction, which, after doubling its volume in 1991, grew at a rate of over $30 \%$. Services, the mainstay of the Panamanian economy, showed an overall trend towards recovering their levels of activity prior to the crisis of the late 1980s. Commerce in general, and in the Free Trade Zone in particular, increased as a result of bank intermediation. The Panamanian banking system was more dynamic than the international banking system in a climate of renewed competition for deposits among the various financial institutions. The manufacturing industry slightly outpaced total GDP, but there were vast discrepancies in the performance of different branches, while the agricultural sector expanded more slowly. Unemployment decreased from $20 \%$ to $18 \%$, especially as a result of the creation of many temporary construction jobs.

In the Caribbean countries, overall performance was rather dismal. The Dominican Republic was an exception. There, after two years, of decline in gross domestic product, it recovered significantly $(7.5 \%)$, stimulated by higher domestic demand and the export of services. Public investment grew more rapidly than private investment, while private consumption rose more quickly than government consumption. This turnaround was facilitated by a more stable macroeconomic environment, which included exchange rate stability and control of the inflationary process. Mining was the only sector in which the level of activity was lower, continuing the decline of the preceding four-year period, partly as a result of the drop in iron-nickel production in reaction to lower international prices, and partly because of the lower levels of gold and silver mining. Construction, on the other hand, was a more energetic sector, principally because of increased public investment in installations preparatory to the Quincentennial. The agricultural sector expanded more rapidly, while the manufacturing industry posted a sharp increase after its poor performance in the preceding biennium, although its main activity, the sugar industry, suffered a deep slump.

In 1992, the economic crisis in Cuba worsened. In the wake of a renewed economic blockade by the Government of the United States and the discontinuation of its advantageous trade relations with the eastern European countries, and especially with the former Soviet Union. There was a further decline in output and in the import of goods and services. Import capacity decreased by $73 \%$ compared to 1989 , and was reflected in the scarcity of raw materials, equipment, spare parts, capital goods, and foodstuffs, but, above all, energy products. This in turn caused aggregate supply to plunge. Both domestic demand and the demand for exported goods and services decreased. Gross fixed investment also went down, despite active investments in the tourism industry. A major stride was also made in foreign investment, with the formation of nearly 80 joint ventures, mainly in tourist-related activities, basic industries, iron and steel manufactures, construction materials and agriculture.

In Haiti, the trade embargo declared by the Organization of American States (OAS), following the collapse of the constitutional Government and the cutoff of generally highly concessional external financing, had a severe negative impact on the level of activity, which decreased by $5 \%$. Hardest hit was the inbond assembly industry, which, in normal times, is a source of between 40,000 and 50,000 jobs and of nearly $50 \%$ of Haiti's total exports. The slowdown in this activity caused a loss of around 25,000 jobs in 1992. The partial incapacitation of imports also affected industries producing for the domestic market.

\section{Prices and wages}

With a few exceptions, in 1992 inflation in Latin America and the Caribbean continued to subside; none the less, the persistent inflationary trend in Brazil a monthly rate of 
over $20 \%$ doubled the regional weighted average, which rose to an annual $410 \%$. Excluding Brazil, inflation fell to only $22 \%$, less than half the 1991 level and way below the $900 \%$ registered two years earlier (see table 5).

There are four main groups of countries, each very different from the other. Brazil has by far the highest rate, with an annual price increase on the order of $1,130 \%$. The second group, composed of Ecuador, Peru and Uruguay, registered an annual inflation rate on the order of $60 \%$. Third there are Colombia and Venezuela, with annual inflation rates close to $30 \%$; and lastly, there are those countries with rates below 20\%: Argentina, Barbados, Bolivia, Chile, Costa Rica, the Dominican Republic, El Salvador, Guatemala, Haiti, Honduras, Jamaica, Mexico, Nicaragua, Panama, Paraguay, and Trinidad and Tobago (see figures 5,6 and 7 ).

Macroeconomic policy in Brazil stood in sharp contrast to that observed elsewhere in the region, owing chiefly to the current system of monthly indexing which introduces a highly inertial component into inflation, to more relaxed fiscal management and to the deep domestic indebtedness of the public sector. Monetary policy thus became the only tool for controlling inflation, which resulted in high real interest rates and lower output. Brazil consequently is in a difficult situation, characterized by high inflation with recession.

By contrast, in most countries of the region, domestic price stabilization continued to be the focal point of macroeconomic policy. In that respect, the effort to achieve financial equilibrium in the public sector was stepped up, prudent monetary policies were adopted and exchange rate trends were monitored in order to ensure compatibility with anti-inflationary goals. Some countries (Bolivia, Honduras, Nicaragua), all of whose economies operate on a smaller scale, maintained or even widened their already considerable fiscal deficits, but this had no effect on domestic prices because of abundant financing from abroad, largely in the form of official assistance. In other cases, however (Ecuador, El Salvador, Guatemala, Paraguay and Venezuela), more relaxed fiscal management caused incipient flare-ups of inflation, with certain signs of repressed prices in those countries where there was lagged adjustment of prices and public-sector rates.

Capital inflows continued to be high in some countries; in these cases, local currencies continued to appreciate (see table 9), bolstering stabilization efforts, but with the related build-up of international reserves making it more difficult to implement monetary policy. In other cases, a desaceleration of short-term foreign capital inflows permitted authorities to break the cycle of monetary expansion through the purchase of foreign currency and the simultaneous increase in the domestic interest rate as a result of the sterilization of the excess money supply. Tariff reduction and trade liberalization programmes, which often coincided with the appreciation of local currency, also reinforced disinflation by stimulating an increase in the aggregate supply, with the increase in imports at lower domestic prices.

Everywhere, consumer prices rose much more rapidly than wholesale prices. A crucial factor behind this was the more rapid upswing in the prices of non-tradeable goods in increasingly segmented markets, where private demand was greater and public services were curtailed.

Stabilization efforts were particularly successful in Argentina and Nicaragua, which in the space of two years, not only escaped hyperinflation but also brought down the rate of consumer price increases, to an annual $18 \%$ in Argentina and to only $2 \%$ in Nicaragua. In both cases, the achievement of stability was based on the determination of fixed parity between the local currency and the dollar, in a climate where external financing was plentiful and fiscal management was under control (equilibrium in Argentina and externally financed deficit in Nicaragua; see table 8). Also, in both Argentina and Nicaragua, with the stimulus of a slow but steady rise in the relative prices of non-tradeable goods and services, the current-account deficit widened. Stabilization was accompanied by a substantial recovery of production in Argentina, but, in Nicaragua, the adjustment, stabilization and restructuring programme kept the economy in a recession.

The other high-inflation countries continued to encounter difficulties in de-activating their inflationary processes. In Peru, progress in the stabilization programme was significant, consolidating the reversal of the hyperinflationary trend of the 1988-1990 triennium; however, the lowering of inflation from $140 \%$ in 1991 to less than $60 \%$ in 1992 took place amid a recession. Inertial elements remained very strong in Uruguay; this and a considerable external demand largely the overflow of Argentine domestic demand prevented a more rapid slowdown of inflation, which, in any case, decreased from slightly more than $80 \%$ in 1991 to less than $60 \%$ in 1992 . Ecuador, which rounds out the set of four countries with the highest inflation in 1992 , is a special case, since fiscal and foreign exchange adjustment measures taken by the new Government caused a price surge in the second half of the year; consumer prices thus increased by nearly $65 \%$ in 1992 , after remaining firmly at $50 \%$ for three years. The process of high inflation in Ecuador and Uruguay however, is occurring in a context of sustained economic growth.

On a smaller scale, on the order of $30 \%$ annually, Colombia and Venezuela also encountered strong resistance to their efforts to drive down the rate of inflation. It went down only slightly in Colombia, under more relaxed fiscal and monetary policies, but went up in Venezuela in the context of growing fiscal distortion. In any case, both countries continued on a course of steady growth; the figures were particularly high in Venezuela.

Those countries whose economies were subject to structural adjustment and, during the previous year, had managed to control surges of inflation, made further progress towards stabilization within a framework of sustained growth. The process was particularly successful in Chile, which decreased its annual rate of inflation from $18 \%$ to $14 \%$ in conjunction with sharp increases in aggregate demand. Bolivia and Mexico also managed to slow the rate of domestic price increases, to $11 \%$ and $13 \%$, respectively, and simultaneously keep expanding production, but their growth rates were more moderate. Paraguay alone was worse off; its rate of inflation rose from $12 \%$ to $17 \%$.

Stabilization processes were consolidated in several Central American and Caribbean countries. Annual inflation was higher than $15 \%$ in only three of them, Costa Rica, EI Salvador and Haiti; the others were below $10 \%$. Despite these low rates, there were surges of inflation in the Dominican Republic, El Salvador, Guatemala, and Trinidad and Tobago. Rapid price stabilization in Jamaica, which brought its annual rate of inflation down to $13 \%$, after it had shot up to $77 \%$ in 1991 , was a highlight of the year among this group.

In general, based on the scant information available, it would seem that the purchasing power of average salaries and wages increased in 1992. In Argentina and Colombia, real wages remained unchanged but they went up in the other countries. In some cases (Chile, Mexico, Uruguay), this meant that the workers benefited in part from the more productive economy; in Brazil, after a year of severe decline, real wages paid to workers in the largest cities increased, most likely owing to systems providing for more frequent than usual wage adjustments. In any case, with very few exceptions, current real wage levels are well below what they were before the external debt crisis. 
a) Stabilization in countries with chronic high inflation

Economies traditionally steeped in high-inflation processes have responded differently. Thus, while Brazil again registered exceedingly high monthly rates, Argentina and Nicaragua made significant progress. Peru and Uruguay slowly but surely brought down their rates of consumer price increases, while Ecuador and Venezuela experienced surges of inflation.

Brazil was a glaring exception in the region with an annual price increase on the order of $1,130 \%$. In 1992, it represented an isolated case of chronic high inflation and little progress in achieving basic macroeconomic equilibria. Brazilian economic policy continued the measures taken in the fourth quarter of 1991, including the deregulation of most prices, the containment of public expenditure and higher domestic interest rates designed to reduce liquidity. An obstacle to the last-named objective was the considerable build-up of international reserves, which occurred in large part because of a foreign exchange policy which sought to maintain a competitive real exchange rate. Meanwhile, the tariff reduction programme and the privatization of public enterprises were pursued. Measures to reduce indexing mechanisms built into wage adjustments were also adopted.

None the less, monthly inflation never dropped below $20 \%$. The rate of consumer price increases slid in the first half of the year, but ther., against the backdrop of the political events that culminated with the suspension of the President of the Republic, negative expectations again pushed up the inflation rate to a high of $26 \%$ in October. This situation was caused essentially by widespread indexing of prices, the high level of domestic indebtedness of the public sector which requires high real positive interest rates in order to prevent sell-offs of its financial assets and the acquisition by the Central Bank of a substantial private-sector foreign currency surplus without the counterpart public sector surplus need to finance said purchases. In addition to all this, there was the release of all the financial assets which had been frozen in 1990, coupled with a huge inflow of foreign capital.

The unfreezing of resources under the First Collor Plan resulted in a monthly monetary expansion of US $\$ 1.5$ billion; although around $40 \%$ of this remained locked up in special Central Bank deposits, attracted by high interest rates, the rest placed pressure on the monetary base. Added to this was the expansion resulting from the build-up in international reserves. In order to forestall a considerable increase in liquidity, the Central Bank took steps to decrease the money supply by placing federal Government securities on the open market; the volume of these operations increased from $3 \%$ to $9 \%$ of GDP between December 1991 and October 1992. In this context, both the monetary base and the supply of credit increased fivefold in the first 10 months of the year, while consumer prices increased eightfold; as a corollary, the monthly real interest rate went as high as $5 \%$.

The $10 \%$ drop in real terms in tax revenue created fiscal adjustment problems. Although tax indexation measures were adopted in January, suits were filed questioning the legality of certain taxes, and taxpayers suspended their payments pending the courts' decision. In view of the shortage of cash caused by this delay in tax payments, the lower level of activity and the pledges made to multilateral and bilateral organizations, both current and capital public expenditures were curtailed. Public wage adjustment lagged behind inflation, and hence payments of salaries and wages fell by $13 \%$ in real terms. Overall, real expenditure by the federal Government was $11 \%$ lower, which made it possible to maintain a real positive cash flow until October. None the less, the high cost of domestic indebtedness, the higher interest paid on the external debt under agreements reached with bank creditors, multilateral agencies and the Paris Club and the erosion in real terms of rates and prices charged by State enterprises in the final months of the year, created a public-sector operating deficit on the order of $1.5 \%$ of GDP, upsetting the balance achieved the year before.

In view of the fragility of public accounts, a fiscal reform package was submitted to the National Congress in July. It provided for tax restructuring, a surcharge on financial transactions, the elimination of income taxes, a modification of the system of social benefits, a change in the distribution of public-sector transfers and regulations for increasing the job mobility of civil servants. The privatization process also continued: between September 1991 and October 1992, 14 companies were sold for a total of over US\$4 billion.

External debt-restructuring agreements revived expectations, which in turn attracted a major inflow of external capital to the private sector and State-owned enterprises, such as PETROBRAS and Vale do Rio Doce, especially in the first half of the year. Beginning in July, the political crisis affected the inflow of capital, and there was even a net outflow on the stock exchanges of around US\$350 million, in contrast to the increase of US\$1.5 billion in the first half. There were a number of reasons for the huge inflow of external capital. In the first place, the high domestic interest rates were extremely attractive. Equally attractive was the yield on stocks listed on the exchange; between January and May, the So Paulo stock exchange index (in local currency) rose in real terms by $52 \%$, although it later fell, posting a loss in real terms between January and November (see table 18). In turn, the very healthy positive trade balance and the foreign exchange policy were aimed at achieving a certain degree of exchange-rate stability.

Lastly, the economic authorities considerably eased the restrictions on financial transactions with other countries, although at the end of the first six months, the Central Bank established minimum terms for the investment of foreign resources in national enterprises raising the minimum maturity on bonds and commercial paper to 30 months. This extraordinary inflow of resources complicated the country's price stabilization strategy, based on reducing the monetary base, because authorities had to sterilize the primary expansion, originating in the purchase of foreign currency, by selling instruments at attractive interest rates. This action triggered a feedback process between rates and liquidity, as well as increased domestic indebtedness and hence the financial needs of the public sector.

The salary and wage policy introduced in January, designed to limit the widespread indexation of costs, involved partial adjustments with past inflation every two months and full adjustments every four months, only for the wages of private-sector workers which were equal to less than three times the minimum wage. In March it was decided that the minimum wage would be adjusted every four months. Some sectors, however, made more frequent adjustments; hence the average real industrial wage in So Paulo rose by $10 \%$, after having fallen considerably in 1991, while the wage increase for workers in Rio de Janeiro was even higher.

Peru, which was still having difficulties in achieving its basic economic equilibria, again brought down its rate of inflation significantly, from $139 \%$ in 1991 to $57 \%$ in 1992. This decline, even more impressive if compared to the $7,650 \%$ rate in 1990 , was accompanied, however, by a slowdown in domestic production, a less favourable trade balance and a financial crisis.

In the first few months, economic policy continued to be based on a drastic reduction of the money supply which pushed up domestic interest rates. At the same time, this led to an inflow of external 
capital basically attracted by the differenial with international interest rates the erosion of the real exchange rate and a contraction of the domestic market. On top of this, a crisis emerged in the financial system which, in the course of the year, led to the intervention or liquidation of around 20 private non-banking institutions and the closing of four State-run development banks.

The political uncertainty created by the institutional breakdown in April unleashed a run on bank deposits and caused a significant draw-down in international reserves in the following two months. The greater demand for foreign currency in turn caused the local currency to depreciate. Once the political uncertainty had blown over, external resources began to flow in again. As a result, Central Bank intervention in the foreign exchange market increased in order to maintain a minimum rate against the dollar. Thus, the real exchange rate improved with respect to end year 1991. Official intervention in the exchange market also built up international reserves on the order of US\$475 million during the year. In any event, the real value of the local currency vis-a-vis the dollar was much higher than that prevailing in the 1980s.

The growth of reserves was the key component of the primary emission. The expansion of domestic credit by the Central Bank was limited; while credit to the private sector (especially to the banking system) doubled, this was mostly offset by the tightening of credit to the public sector. Lower reserve requirements on local currency deposits, down from $23 \%$ to $21 \%$, and the elimination of the marginal minimum reserve requirement of $5 \%$, contributed to the expansion of nearly $70 \%$ in the money supply. As local currency deposits increased significantly, total liquidity expanded by around $90 \%$. In the money market, there continued to be an enormous spread between interest rates on deposits and loans; in the second half of the year while annual interest rates on deposits were around $3 \%$ in real terms, annual real lending rates were over $65 \%$. This revealed a great deal about the high risk premium fixed by the banking system in granting loans, which took into account the possibility of devaluation and risks of late payment.

Monetary expansion and the increase in the key cost factors led to a gradual slowdown of inflation, which still stood at a monthly rate of about $3-4 \%$ in the closing months of the year. These costs included high interest rates on loans, the policy of monthly readjustments of fuel prices and public tariffs (including the pre-announced adjustments of electricity prices which, had a bearing on expectations) and the higher rate of the dollar in the second six months of the year.

The monthly adjustment of prices and public tariffs was not sufficient, however, to maintain their value in real terms, which affected public enterprises management. In turn, it seems that the central Government held its financial imbalance at around $1 \%$ of GDP, as a result of income equal to $12 \%$ of output and expenditures, which included current outlays on the order of $11 \%$ of GDP and capital expenditures equal to $2 \%$ of GDP. Tax receipts ( $9 \%$ of GDP) increased by about $6 \%$ in real terms, mainly as a result of sales taxes (at a rate that moved from $16 \%$ to $18 \%$ during the year) and income taxes.

Argentina made significant progress in the control of its long drawn-out inflationary process. The $18 \%$ increase in consumer prices (84\% in 1991) was the lowest since 1969. The increase in the wholesale price index (WPI), however, was no more than $4 \%$, while the exchange rate remained fixed, as established by the Convertibility Act put into effect in April 1991.

Macroeconomic policy functioned, as it had since 1991, within the monetary framework established by the Convertibility Act. This forced the Central Bank to sell dollars, if necessary, at a fixed price of one peso and to maintain reserves in an amount no less than the monetary base; meanwhile fiscal administration was focused on the elimination of the financial imbalance. In fact, once capital revenue from privatization, amounting to around $2 \%$ of GDP, was entered on the books, the national public-sector financing requirements was virtually nil, which in turn temporarily improved on the 1991 deficit representing $2 \%$ of output. While central Government expenditures rose considerably owing especially to the higher appropriations to the pension system and transfers to the provinces through revenue sharing resources were even more plentiful. The increase in tax receipts partly reflected a change in the tax structure, which included consolidation of the broad-based tax burden and lower weighting of the surcharges on bank overdrafts and various public services. Especially noteworthy was the increase in income from the value-added tax (NAT), which is proving to be a key element in the tax scheme. There were a number of reasons for this increase: the upward trend in the level of activity, the higher tax rate (which was raised to $18 \%$ early in the year) and, perhaps most importantly of all, a lower percentage of evasion.

Two aspects of the fiscal policy which were also stressed were the relationship between the central Government and the provinces and the design and evolution of the social security system. In this connection, in 1992, the provinces took over various health and education services formerly provided by the federal Government. Changes in the allocation of tax revenue were also adopted. Under this new arrangement, the national Government made a commitment to transfer a given volume of resources to the provinces and more funds were earmarked for retirement pensions. Through the issue of bonds, the Government also consolidated its obligations to retired persons, whose pensions were being paid below the legally prescribed amount. $A$ bill to reform the retirement system was also submitted to Congress.

Activities relating to the privatization of public enterprises gained tremendous momentum. At the beginning of the year, the Government placed shares in a telephone company on the market, at a time when the demand for such paper was very high. The State-run iron and steol enterprises were also sold off, including SOMISA, the leading firm in the sector. The generation and supply of gas throughout the country, the water supply and part of the electricity generation and supply facilities in the capital city were also privatized. In an isolated exception to the overall trend towards disposing of State assets, the Government increased its stake in Aerolíneas Argentinas, an already privatized company that was having operating difficulties.

In view of the convertibility scheme and the fact that financing to the Government did not serve as an additional source of money, the monetary situation continued to be determined mainly by the balance of payments and, in particular, by the trends in financial flows. In 1992, capital inflows which attained exceptional levels, visibly higher than in any preceding period were triggered by very specific international conditions, by privatization and by what was perceived as the lower risk of holding assets in Argentina. This was also reflected in the rapid growth of dollar deposits in local banks.

Financial markets during the first part of the year continued with the same trends that were prevalent at the end of the previous year. Interest rates on local-currency deposits were less than $1 \%$ a month, whereas, even though spreads were very high, lending rates tended to decline. The stock market continued to show strong demand, which raised prices. That behaviour, however, turned around: share prices fell sharply, plummeting in early December to levels below those of July of the previous year. Besides profit- taking, 
that movement probably reflected a revision of what had been highly optimistic expectations and perhaps a slower inflow of external funds as well. Although to a much lesser extent, bond prices in local currency also fell. Nevertheless, until November no appreciable chanjes were observed in bank interest and exchange rate trends. Demand for foreign exchange increased sharply during that month, which forced the Central Bank to sell dollars for the first time since the convertibility plan began. Although the episode was brief and far from a massive run on reserves, interest rates rose. In order to improve expectations as well as lower interest rates, the authorities announced that they would allow reserve requirements on peso deposits to be paid in foreign currency and that current accounts in dollars could be opened.

Consumer prices were erratic. Trends differed especially in prices for non-tradeable foodstuffs and for services. Even though the rise in the consumer price index was much lower than in the past, it was still significant. During the first quarter, the aggregate index averaged $2.4 \%$ per month, considerably higher than in the last part of 1991. Several elements combined to explain this acceleration: a rise in food prices (which had declined seasonally in November and December of the preceding year), seasonal rises for certain services and the impact of the higher rate on the value added tax, which compounded to an upward trend in items such as rents. Nevertheless, the phenomenon was not sufficiently widespread to make the upswing in inflation more persistent. Although demand was sustained, thereby facilitating the gradual upward adjustment of prices of services, the variation in more flexibly-priced goods helped moderate the rise in the consumer price index during the second quarter, which was less than $1 \%$ per month. Prices rose somewhat more quickly during the following months. Food price declines in November once again led to a significant slow-down.

Thus, relative prices took on a special configuration: from already high levels, consumer prices rose in relation to wholesale prices and something similar happened to prices of services in relation to those of goods. This was reflected in the real exchange-rate indicators, which were less competitive in relation to the consumer price index but not so in relation to the wholesale price index. In any case, the relative decline in the price of tradeable goods was a key factor in the huge upsurge in imports, which grew by about $75 \%$ after doubling in 1991. Thus, even though exports increased slightly, the trade balance registered a significant deficit, while the balance-of-payments current account deficit swelled, This latter was easily financed by an abundant inflow of capital, in part from privatizations. Despite the I arge volume of that inflow, the external debt was reduced, owing to the reduction established in the Brady accord with commercial banks and the retirement of claims through the sale of public assets. In late October, the Government announced the application of drawbacks on exports and changes in tariff rates on imports, together with an increase (from 3\% to 10\%) in the so-called "Statistical tax" on all imports, including those from the Southern Common Market (Mercosur) countries. Those measures raised effective exchange rates for foreign trade operations.

Generally speaking, throughout 1992 agents adapted to operating under conditions of moderate inflation. Apart from the fluctuations caused by temporary factors, the inflation rate tended to decline slowly. However, inflation had not yet been brought into line with international levels, and domestic prices showed an appreciable increase, despite a firm exchange-rate anchor.

The rise in the level of economic activity apparently not only improved employment figures but also the labour supply. Thus, the unemployment rate in May was higher than the year before. Simultaneously, nominal wages in the private sector crept upward, more or less keeping pace with the consumer price index. This was caused neither by explicit indexation schemes (which would have violated express government regulations) nor informal practices of automatic adjustment. Rather, wages were adapting with apparently longer adjustment periods to labour-market conditions. Ultimately, real wages (in relation to the consumer price index) remained at levels between the minimum reached during periods of hyperinflation and those in effect before those episodes. In contrast, wages in terms of industrial prices were above past averages.

Nicaragua was another country that made outstanding progress on the road to stabilization. Inflation plunged from $775 \%$ in 1991 to only $2 \%$ in 1992 . The halt of hyperinflation the previous year was thus consolidated in 1992, under an economic programme that gave absolute priority to price stability. External financing (including grants-in-aid) of the country's considerable fiscal imbalance and the freezing of the price of the dollar were the main anti-inflationary tools. Indeed, the exchange rate remained unchanged at five cordobas oro to the dollar, even when external payments became problematic and the gap between the official price of the dollar and the parallel market widened to nearly $10 \%$. Fiscal policy remained focused on balancing the current account; according to this approach, current spending should not surpass current income, and investment programmes should be financed with external resources. Although the general sales tax was reduced in February from $15 \%$ to $10 \%$, in order to support the economic recovery of the private sector, the reduction was rescinded in September. In any case, and especially because of the so-called Olivera-Tanzi effect, revenues increased in real terms, bringing current income to $22.5 \%$ of GDP, two percentage points above that of the previous year. Current expenditures fell from $25 \%$ to $23 \%$ of GDP, owing to a decline in purchases of goods and services, cuts in subsidies and a reduction of allowances and benefits to public employees and military personnel, which had become considerable in 1991 when retirement and job retraining programmes were begun. Conversely, wages rose and external debt servicing payments climbed to $2.8 \%$ of GDP. Capital expenditure increased noticeably, from $4 \%$ to $7 \%$ of GDP. Although the proportion of official assistance from abroad declined even so it still represented almost $4 \%$ of GDP external financing was obtained to cover the deficit amounting to some $3.5 \%$ of GDP. Although the central Government did not resort to bank credit, the reconstitution of monetary balances by the public, after the period of high inflation, resulted in an expansion of the money supply of more than $30 \%$. The high interest rates offered by the financial system, even more attractive in dollar terms because of the stability of the nominal exchange rate, led to a significant increase in local-currency time deposits. Dollar deposits, larger than those in local currency, also increased. The rise in available financing was used mainly in agriculture and housing construction.

Some economies, even with high inflation, maintained a situation of "controlled instability" that kept hyperinflation at bay. Such was the case in Ecuador, Uruguay and Venezuela. Those countries behaved in different ways in 1992.

Inflation jumped to $66 \%$ in Ecuador, far surpassing the uniform rate of close to $50 \%$ of the three preceding years. The new Government's inauguration in August marked two clearly different periods. In the first one, a large fiscal deficit, mainly financed by bank credit, combined with a policy of weekly mini-devaluations that were smaller than the variation in domestic prices, and an electoral climate that expected changes in economic policy, all led to a steady decline in international reserves. After increasing during the first quarter, the net international assets of the Central Bank plummeted from US\$700 
million to only US\$225 million in August. The rise in imports, in a climate of an expected large devaluation, was a key factor in the considerable trade deficit during this period. Another factor was the conclusion of the tariff reforms put into effect by the outgoing Government, which lowered the rate on imports of capital goods, inputs and raw materials to $2 \%$, those on other intermediate goods to a range of $7 \%-12 \%$, and the rate on consumer goods to $17 \%$, with the exception of automobiles, for which a rate of $37 \%$ was applied.

The new Government enacted measures to reduce fiscal and external disequilibria. First, it changed the system of weekly mini-devaluations to one with a fixed exchange rate that represented a devaluation of some $35 \%$. The new mechanism split the exchange market, establishing distinct prices for the purchase and sale of foreign currency. Thus, private exports were exchanged on the official market at 2,000 sucres to the dollar, with $15 \%$ being put into a 180-day negotiable security. Simultaneously, importers were authorized to acquire foreign exchange on the open market. The exchange market was further liberalized in November, authorizing exporters to offer their foreign exchange on the open market, although at a minimum price of 1,700 sucres to the dollar, in order to prevent a significant erosion of competitiveness abroad.

The new programme included fiscal adjustment measures, such as a decline in central government spending, early retirement of government employees and a freeze on new hiring, a significant rise in oil prices and electricity rates. A draft law was also submitted, proposing a tax on corporate assets. Monetary policy allowed greater interest-rate flexibility by eliminating the obligatory spread between rates on deposits and loans. Even though the programme called for more monetary constraint, the minimum reserve requirement was reduced by $2 \%$ in September to $32 \%$.

Together with these measures, an emergency social programme was launched, freezing fares on public transport and electricity rates for those who consumed less than $150 \mathrm{~kW}$ per month, an additional wage adjustment of 10,000 sucres and new programmes for health care, education and support for micro-enterprises. As part of the structural reform programme, it was announced that the State would be modernized and that an economic stabilization fund would be established. The immediate result of the adjustments of the exchange rate and energy tariffs was a sharp $11 \%$ rise in consumer prices in September and $6 \%$ in
October. Inflation then appeared to ease to levels similar to those achieved before the new economic programme was put into effect. The fiscal measures, especially the rise in energy prices, substantially improved fiscal performance. Thus, the burdensome deficit of the consolidated public sector recorded during the first half of the year, representing around $7 \%$ of GDP, was brought down to an annualized rate of less than $5 \%$. The combination of high domestic interest rates, a devaluation of the exchange rate and a slow-down in imports led to a substantial improvement in international reserves, which rapidly grew during the first two months of the new programme, surpassing US\$700 million in October, the level attained at the end of the first quarter. This led to a significant rise in the money supply during the last months of the year.

Wage hikes decreed by the outgoing administration at the beginning and middle of the year and the increases granted by the new Government under its macroeconomic stabilization plan maintained the purchasing power of wages, despite the flare-up of inflation.

Uruguay reduced its inflation from $82 \%$ in 1991 to $59 \%$ in 1992 , the lowest recorded in the last five years and substantially below the 1990 figure of $129 \%$. This coincided with the highest GDP growth rate of the last five years. Uruguay's inflation is highly conditioned by inertial factors. It was also affected this year by a rise in demand from Argentina. Indeed, the financial equilibrium of the public sector as a whole, including the quasi-fiscal expenditure of the Central Bank, precluded any pressure to increase the money supply. The combination of a declining real exchange rate and tariff reductions were factors in bringing down costs. However, the heavy demand from the Argentine market, which led to new gains in international reserves, and indexation mechanisms on private contracts, which continued to take into account past inflation, conspired against a more rapid deceleration of consumer prices.

As in the previous year, the consolidated public sector was practically in equilibrium, as a result of a surplus of around $2 \%$ of GDP in the non-financial public sector and a deficit more or less the same size in quasi-fiscal spending. The central Government and public enterprises maintained positive balances. In the former case, income increased once again in real terms, particularly owing to revenues from taxes on domestic transactions, since tax receipts from foreign trade shrank despite a substantial increase in imports. Income increased faster than spending. The higher outlay in wages, social security and non-personal expenditures outstripped the reduction in interest payments and investments. Public enterprises also produced surpluses. Even though rate adjustments were lower than price rises in the private sector, so were wage adjustments and the exchange rate, two of the main variables that affect costs in public enterprises. Finally, the reduction of indebtedness, both external and domestic, and the decline in interest rates once again led to a decline in quasi-fiscal spending.

Both the current and capital accounts of the balance of payments were positive. Thus, for the eighth year in a row the international reserves of the monetary authorities increased, this time by close to US $\$ 150$ million. By November the monetary base had expanded at a rate of $70 \%$ per annum. However, the higher demand for money favoured a large growth of the money supply in real terms. Since real domestic interest rates were negative, time deposits in local currency evolved more slowly. Dollar deposits continued to grow, surpassing US\$5 billion.

In this context, the main inflationary factors were the indexation mechanisms incorporated into the formation of domestic prices and the growth of aggregate demand, mostly met by increasing imports. Based on that diagnosis, the authorities continued to pursue the objective of changing the indexation mechanisms, switching from those that took past inflation into account to others that considered target rates of inflation. To achieve that, the programme carried out during the year slowed down the rate of variation in administered prices, which was to be used as a benchmark for price formation in the private sector.

Since the Uruguayan economy offers extensive freedom of trade, both domestic and foreign, the Government administers only those prices that are related to its own activity, namely, public-sector wages and the prices of government-provided goods and services. It also sets the minimum price the Central Bank will pay for dollars, under an exchange-rate system that allows for fluctuation within a certain band.

The guideline for the variation of these prices, in force since April as part of a programme agreed to with the International Monetary Fund, was $40 \%$ per annum for public tariffs and the exchange rate and $35 \%$ for public-sector wages. It was also suggested that the private sector should adopt $35 \%$ as a yardstick for future collective bargaining; to prevent the Government from refusing to ratify private agreements. This measure sought to eliminate the possibility of having to resort to government guarantees that 
wage-adjustment criteria would be respected in each branch of activity, if they exceeded the guideline of $35 \%$ per year. To a certain extent this meant taking a step toward more flexible labour contracts at the enterprise level, beyond a certain maximum compatible with official targets. In practice, even without official approval, private-sector wages were adjusted above government guidelines.

Although the public sector complied with this programme, private-sector prices were strongly influenced by past inflation (normally the previous four months). Thus, the rate of variation in consumer prices decelerated slowly but steadily. The lower variation in the price of the dollar $(45 \%$ in the 12 months prior to November) led to a smaller variation in the price of tradeable goods. For that reason, wholesale prices rose by only $53 \%$ during the year ending in November 1992. Thus, the real effective exchange rate once again declined, to a lesser extent in relation to consumer prices.

The different ways of adjusting private and public wages widened the gap observed in recent years between the evolution of purchasing power in each sector, since real wages in the private sector rose more than those in the public sector. Overall, real average wages increased by more than $3 \%$ in 1992.

In Venezuela, inflation rose slightly to $33 \%$, on the thin line that separates high-inflationary from moderate-inflationary economies. Economic policy remained unchanged from that of previous years, but in a highly uncertain environment. Political disturbances two attempted coups d'état were aborted during the year were compounded by a softening of the petroleum market, the main source of fiscal revenues. That made it necessary to maintain a restrictive monetary policy, in order to offset the fiscal weakness caused by variations in oil income in the context of highly rigid public expenditures. Exchange-rate policy kept the nominal exchange rate stable until October, easing inflationary pressures but creating uncertainty about exports and contributing to the deterioration of the balance of payments, which registered a current-account deficit for the first time since 1988.

Despite the fact that consumer prices did not change significantly, inflation continued to pose a potential threat. The worst problem was still the persistence of the fiscal crisis, given the peculiarity of Venezuela's public finances, which are extremely dependent on income from abroad. In this context, any increase in public spending financed through that route becomes expansionary, whether or not a deficit is produced, since the bulk of resources are not obtained from the domestic economy.

In 1992, political uncertainty and a swollen financial deficit partly offset by the restrictive action of the monetary policy were the main factors that pushed prices upward. Conversely, the stability of the nominal exchange rate in the framework of a broad trade liberalization helped relieve that pressure.

Faced with a growing fiscal imbalance, the authorities tried to revive the adjustment programme that had been postponed during the second half of 1990, when petroleum income jumped considerably during the Gulf crisis. To do so, cuts were announced in the budget and in spending by the national oil company during the early part of the year. Despite these cuts, the drop in oil-related income from abroad widened the public-sector deficit substantially to close to $8 \%$ of GDP. More than two thirds of that deficit corresponded to the central Government, whose income was nominally reduced while its expenditures rose by $24 \%$. The most significant drop in revenues was represented by taxes on oil profits, which plummeted from a share of almost $14 \%$ of GDP to $8 \%$. Such a decline could not be offset by less pressure from expenditures, which contracted from nearly $25 \%$ to less than $22 \%$ of GDP. The financial balance of public enterprises also eroded, owing to a slow-down in their prices and tariffs. Structural reform continued; however, the privatization programme lost momentum. The free trade agreement with Colombia took effect in March, and this intensified bilateral commerce.

In order to avoid the overexpansion of the money supply that would have resulted from domestic financing of the fiscal deficit, the Central Bank sterilized the excess liquidity through open-market operations at real interest rates on the order of $6 \%$ per annum. This action encouraged many enterprises to repatriate capital invested abroad. The monetary authorities continued to sell long-term, zero-coupon bonds, to which they added at mid-year short-term Treasury bills. The tight monetary policy also included an increase in reserve requirements on both public-and private-sector deposits, although this policy was reversed towards the end of the year.

\section{b) Stabilization in countries with moderate inflation}

Generally speaking, economies with moderate inflation consolidated their stabilization processes, including those that faced high inflation only a few years ago. The few exceptions, where prices climbed somewhat during 1992, did not represent relevant setbacks.

Colombia had the highest inflation in this group; its stable rate barely dropped to less than $26 \%$ for the first time since 1987. Changes in monetary policy and the effects of tariff reduction in 1991 constituted the main differences on the economic scene during 1992. Although the fiscal gap widened during the first half of the year, mid-year tax measures made it possible to limit the deficit to a little less than $1 \%$ of GDP.

Monetary policy had been very restrictive in 1991, in an attempt to sterilize the expansionary effects of the large inflow of foreign currency. The resulting rise in the domestic interest rate, in a context of low international rates, slowed down the rate of activity and simultaneously attracted foreign capital. In 1992, the Banco de la República moved to slow down the inflow of short-term capital (mostly private transfers) by lowering the domestic interest rate. Nevertheless, the monetary authorities continued to accumulate reserves, which led to an expansion of the money supply beyond what was compatible with the inflation target of $22 \%$. However, the combined effect of the tariff reduction, trade liberalization and the erosion of the bilateral exchange rate with the United States put downward pressure on consumer prices, which offset the upward effect of the monetary expansion.

The tariff reduction, the decline in electric power sales caused by a severe drought, the negative effect on public accounts connected with the drop in the international price of coffee and the increase in outlays for the domestic armed conflict substantially widened the fiscal deficit in the first half of the year. Tax reforms were enacted in June to reduce that imbalance, especially a rise in the value added tax to $12 \%$. As predicted, the public-sector deficit dropped considerably during the second half of the year, after having risen to $2 \%$ of GDP during the first half.

The rest of the countries of the region recorded inflation rates of less than $20 \%$ per year. Moreover, in 10 countries the variation in consumer prices was less than $15 \%$ per annum. In general, efforts to stabilize prices were increasingly successful, although inflation did flare up in some countries. Priority was given once again to the search for fiscal equilibrium and external openness.

In Costa Rica, inflation dropped from 25\% in 1991 to $18 \%$ per annum by October 
1992 , in the framework of significant changes in economic policy that accompanied the strategy adopted by the other Central American countries during the preceding two years. The liberalization of the exchange rate in February, the tariff reduction and the elimination of advance deposit requirements and surcharges on imports substantially changed foreign trade policy. Tight monetary management, designed to lower inflation, led to high domestic interest rates which, with the drop in the international interest rate, attracted a considerable volume of external resources. Given the floating exchange-rate system, the inflow of external capital appreciated the local currency, an effect which, even though it helped to reduce inflation, undermined competitiveness. In order to prevent the real exchange rate from eroding, the Central Bank opted to purchase foreign currency, thereby increasing its international reserves by US $\$ 800$ million during the first 11 months of the year. Since that led to a monetary expansion which was out of line with the inflation target, the Central Bank sought to sterilize the excess of liquidity through open-market operations and by increasing reserve requirements. Fiscal policy supported stabilization efforts by reducing the deficit of the central Government to around $2 \%$ of GDP (as compared to $3 \%$ in 1991). The improvement was based on higher tax receipts, mostly as a result of controlling evasion, elimination of a variety of exemptions and modernization of the system for collecting customs duties, which more than offset the drop from $13 \%$ to $12 \%$ in the sales tax. Despite several efforts to significantly reduce public spending, such as the plan for voluntary job mobility which included incentives to lower the number of public employees and laws to rationalize pension systems and limit export subsidies, control of expenditures was less successful.

In a highly dynamic economic setting, inflation in Chlle fell from $19 \%$ in 1991 to $14 \%$ in the 12 months ending in November 1992. Fiscal equilibrium and carefully managed monetary and exchange-rate policies, designed to prevent a high level of domestic demand from putting pressure on prices, together with easy access to external financing, were the main tools of the country's stabilization efforts. The exchange-rate regime consisted of establishing a sliding parity for the peso and a float within an established band, outside the limits of which the Central Bank is obliged to intervene in the foreign-currency market. Thus, monetary policy is exogenous within the band and endogenous outside of it. Stabilization policy, then, is based on a combination of both instruments.
The balance of payments has improved significantly in recent years. In order to preserve Chile's competitiveness, the monetary authorities avoided a significant revaluation of the local currency by introducing exchange-rate innovations designed to generate uncertainty about short-term yields and by adopting selective measures affecting the capital account. These latter sought to stimulate demand for foreign currency by relaxing regulations on remittances and authorizing investments abroad of a limited percentage of private pension funds, and by limiting the supply of foreign currency by making foreign credit more expensive through reserve requirements and increases in retention periods. The Central Bank revalued the peso by $5 \%$ in January and widened the band from $5 \%$ to $10 \%$ in relation to the agreed rate for the dollar (the pivotal point of the band). It also extended to banks' foreign-currency deposits a reserve requirement of $20 \%$, applied to foreign credit. This increased the exchange risk of short-term operations and successfully slowed down the expansion of the money supply, derived from exchange operations during the first quarter, a trend that was reversed in the second quarter.

The market continued its downward pressure on the price of the dollar, given the differential between domestic and external interest rates and high expectations of a revaluation. In March, a "dirty float" within the band was introduced to cushion fluctuations in the price of foreign currency. Exchange-rate regulations were modified at the beginning of July, linking the price of the peso to a basket of currencies, with each weighted according to the relative importance of its respective monetary area in Chile's foreign trade. That heightened uncertainty about the exchange rate, since the value of the agreed price for the dollar and its corresponding band began to be estimated on a daily basis, according to the international prices of the currencies comprising the basket. In practice, the policy eliminated an implicit exchange-rate insurance which the Central Bank maintained against variations of the dollar in relation to the mark and the yen, raising the risk of borrowing dollars and limiting the expansion of the private sector's burgeoning external indebtedness $(26 \%$ in the first half of the year). The inflow of capital was effectively weakened in August and September, closing the gap between the market dollar rate and the official rate to values of between $3 \%$ and $5 \%$. During the first half of November, however, the gap widened to $9 \%$, only $1 \%$ above the floor of the band.

The main economic-policy concern was the macroeconomic management of the boom, to avoid overheating the economy and to sustain a real exchange rate compatible with furthering the country's export strategy. By the end of the third quarter, there were clear signs of an overexpansion of spending, which had reached an annual rate of $15 \%$. The rises in interest rates applied by the Central Bank in March and August were proving to be insufficient to adjust the increase in spending to a rate compatible with the target of a declining inflation. Thus, rates were adjusted once again at the end of October, when the rate on the Bank's 90-day readjustable certificates rose from $5.7 \%$ to $6.5 \%$. At the same time, the Central Bank tried to neutralize the arbitrage difference with international interest rates, raising the financial cost of the inflow of capital. However, given the strengthening of the dollar on international markets, there was a depreciation of the local currency with respect to other currencies.

The government general policy management joined the stabilization efforts. Fiscal accounts for the first half of the year showed a real growth of $8 \%$ in revenues and more than $4 \%$ in current expenditures, producing a current saving of $2.7 \%$ of GDP. Capital expenditures rose by $13 \%$, leaving, however, an overall public surplus of $1.8 \%$ of GDP, most of which was used to amortize government debt. Strong growth of economic activity enabled tax receipts in local currency to compensate for a decline in copper income. The recent approval of the 1993 budget included a regulation designed to preserve fiscal discipline. Considering the favourable perspectives for growth next year, the public sector will be obliged to save or will require a special law to spend resources that surpass $10 \%$ of budgeted income.

The minimum wage and public-sector remunerations were adjusted on the basis of expected inflation, tying wage hikes to productivity increases. Thus, in 1992, both employment and real wages rose by around $4 \%$. Recent collective bargaining in the public sector was based on an inflation rate of $11 \%$, the rate projected in the 1993 budget.

Mexico once again reduced inflation in 1992 , this time from $19 \%$ to $13 \%$, in the framework of the Social Pact for Stability and Economic Growth put into effect three years ago. Fiscal, monetary and credit-related discipline, a limited crawling peg exchange rate in the context of a substantial inflow of external capital and rising international reserves, and continued efforts to build consensus strengthened the downward trend in inflation. Thus, while wage adjustments and the rise in the price of energy-related products in November 1991 raised the monthly rate of variation in 
consumer prices to 2.4\%, from April 1992 onward it fell to less than $1 \%$ per month.

Fiscal policy continued to play a key role in the fight against inflation. The financial balance was positive for the secnnd year in a row, due to the continuation of zolicies to increase revenues and ieduce expenditures. The year is estimated to be closing with a surplus equivalent to $3.4 \%$ of GDP, which compares favourably with the $1.8 \%$ obtained in 1991 . Excluding the non-recurrent income from the sale of State-owned enterprises, the financial surplus would be $0.4 \%$ of GDP, as opposed to a deficit of $1.5 \%$ the previous year.

Government earnings continued to rise, thanks to an expansion of economic activity and a broader tax base. Real public-sector income is expected to rise by $3 \%$ in 1992 , basically owing to the greater buoyancy of federal Government receipts. Income rose despite the fact that the drop in the value added tax from $15 \%$ to $10 \%$ was in effect throughout the year, having been enacted in November 1991. Offsetting that were rises in income-tax receipts and taxes linked to higher gasoline prices and imports.

The consolidated public sector's net spending was reduced by almost $4 \%$ in real terms, owing to lower interest payments on government debt, which had fallen by $23 \%$ in real terms by the month of September, compared to the year before, as a result of the restructuring of the external debt, lower international interest rates and a decline in the amount of domestic debt. Federal Government spending rose by $8 \%$ in real terms during the first nine months of the year, basically because of rises in current outlays (16\%) and, to a lesser extent, in capital expenditure $(2 \%)$. Spending on social development continued to increase; it is preliminarily estimated to have grown by $13 \%$ in real terms, reaching close to half of programmable expenditures. Outlays rose particularly for education (15\%), health care $(8 \%)$ and for the national provisions programme (25\%). Spending channelled through the National Solidarity Programme are expected to increase by more than a third. The process of privatizing commercial banks ended in 1992, providing total income of US $\$ 12$ billion. A second block of Mexican Telephone Company shares was put up for sale, and other enterprises were sold. The non-recurrent resources obtained from privatizations were used to reduce government debt.

As in previous years, the supply of products from abroad helped lower inflationary pressures, with prices of tradeable goods rising more slowly than those of non-tradeables. From December 1991 to October 1992, prices of tradeable goods rose by $8 \%$, while those for non-tradeable goods climbed by $16 \%$. The slow nominal depreciation of the local currency, which up until October involved adjustments of only 20 centavos a day (around $2 \%$ per annum), was related to these results.

The large inflow of external resources continued to support the stabilization programme and the growth of the Mexican economy. Some financial flows fluctuated during the year, however. Interrupting the strong growth it had displayed for more than a year, the index of local-currency prices and quotations on the Mexican stock exchange began to show signs of softening in March. A 30\% drop in the second four months put the index $7 \%$ below the nominal level recorded on 31 December 1991; this trend reversed itself in October.

From March onward, monetary policy was tightened, in order to relieve inflationary pressures and contain the negative effects of the instability of certain flows of external capital. Accordingly, a maximum limit of $10 \%$ was established on the proportion of liabilities that commercial banks could hold in foreign currency. Interest rates were also raised. While interest on 28-day Treasury certificates (CETES) had declined by more than $4 \%$ in March, it returned to $17.5 \%$ in September and reached $19.7 \%$ in mid-October. The signing of the new version of the social pact brought greater stability to the money market, with interest rates declining slightly. From then on rates on 28-day CETES declined systematically to reach $17.5 \%$ by the end of November.

The real increase in the money supply was around $12 \%$, reflecting the remonetization of a growing economy on the road to lower inflation. Financial saving (M4) in January-September 1992 recorded a real increase of $5 \%$ over the same period in 1991, while commercial bank deposits rose at a real rate of $19 \%$ per year. Although financing granted to the private sector rose by $35 \%$ in real terms, it was partially offset by a reduction in public-sector financing.

The Pact for Stability, Competitiveness and Employment was signed on 20 October, in which it was agreed to reinforce fiscal discipline without raising taxes, to gradually adjust public-sector prices and tariffs up to a maximum of $10 \%$ over 12 months and to increase the variation in the maximum quotation for the dollar from 20 centavos to 40 centavos per day. The Pact also recommended a rise of nearly $7.5 \%$ in nominal minimum wages, beginning in January 1993. The reform of economic institutions continued during 1992. Besides advances in the privatization of government enterprises, other important steps included the reform of agricultural regulations, the restructuring of the State-owned oil company (PEMEX) and changes in pension systems. More than 10 million workers had opened individual bank accounts by September in the new retirement savings system established in February.

Although the agreements reached under the Pact meant that the legal minimum wage rose more slowly than domestic prices, the real average wage of urban workers, on which industrial workers have a special impact, grew by $8 \%$. Nevertheless, it still remains $15 \%$ below its 1980 level.

Inflation accelerated in Paraguay to $17 \%$ per annum (12\% in 1991). During the preceding year, the stability of the nominal exchange rate, linked to an abundant inflow of foreign currency, was one of the main factors in slowing down consumer prices, which had risen by $44 \%$ in 1990 . In 1992 , the decline in the domestic interest rate and the uncertainty created by the failure of some financial institutions put a damper on the inflow of short-term capital during the year. The non-financial public sector recorded a deficit of $0.5 \%$ of GDP, as opposed to a surplus of $1.5 \%$ the year before. Central government revenues grew by close to $4 \%$ in real terms; even though tariffs were reduced and simplified in June, receipts increased. That was mostly due to the introduction of a value added tax of $10 \%$, which replaced and extended the coverage of the general sales tax. Current expenditures, however, increased even more, and government-run enterprises earned less, owing to the freeze on prices and tariffs in effect since December.

Although a programme of financial support for the agricultural sector affected by poor weather and a decline in international prices based on rediscounts at low interest rates was announced in August, it was only put into effect in October. Monetary policy remained tight, to the point that the money supply declined in nominal terms over the 12-month period ending in August. Also, in October the Central Bank intervened in the foreign-currency market to prevent the local currency from depreciating more rapidly; the move reduced liquidity and raised the interbank interest rate from $24 \%$ to $36 \%$ per annum. The monetary authorities also sought to restrict the inflow of short-term capital, in order to maintain tighter control over monetary policy. For that purpose, at the end of April the Central Bank raised the interest-bearing reserve requirements on foreign-currency deposits from $25 \%$ to $30 \%$. Shortly before that, the banks were authorized to grant foreign-currency loans based on the external credits they obtained and on their foreign-currency deposits. The drop in the supply of foreign currency made it possible, unlike the previous year, to 
devalue the local currency by around $18 \%$ during 1992, which, despite the restrictive monetary policy, was one of the causes of the rise in inflation.

The minimum wage was raised by $10 \%$ in July; with that, the purchasing power of those remunerations which are influenced by this legal minimum fell once more.

Bolivia maintained price stability while speeding up its growth rate. Inflation dropped to only $11 \%$ in 1992, under a strict monetary policy and an abundant flow of external resources which made it possible to finance the non-financial public-sector deficit of around $3 \%$ of GDP. To reduce the fiscal imbalance, fuel prices were raised by $13 \%$ and the value added tax from $10 \%$ to $13 \%$. The reduction of the inflation rate led to a gradual decline in nominal interest rates. In any case, the real annual interest paid on bank loans in local currency and rates for loans in dollars was around $18 \%$. The slow movement of the price of the dollar, close to $9 \%$ over the course of the year, in a context of growing international reserves, helped to keep domestic prices stable. The real effective exchange rate for trade, however, improved again owing to a change in the parity with Argentina.

In 1992, Honduras consolidated the price stability it achieved during the second half of the preceding year. The annual inflation rate fell from $21 \%$ to only $5 \%$, based on a style of that avoided bank credit, limited monetary expansion, relative stability of the nominal exchange rate, steady domestic oil prices and an adequate supply of basic grains, which led to an increase of only $2 \%$ in food prices. The financial deficit of the central Government almost doubled in relation to the year before, climbing from $3 \%$ to almost $6 \%$ of GDP. The growth of the deficit was due to an increase in capital expenditure, mostly for highway repairs, since the Government's current saving grew. Indeed, current income surpassed the gradual increase in spending, even though taxes on exports were eliminated and the tax base for customs duties did not follow the variation of the exchange rate. The surplus earned by public enterprises, however, reduced the deficit of the non-financial public sector to less than $3 \%$ of GDP. In any case, the rise in the deficit put no pressure on monetary expansion, since grants-in-aid and sufficient external financing were obtained to close the overall gap. The elimination of the subsidy on rediscounts for the production and marketing of basic grains was an important step in the programme to eliminate quasi-fiscal spending. The decline in credits granted to the public sector allowed for increased loans to the private sector by more than $10 \%$ in real terms. This led the money supply to increase by more than
$10 \%$ in nominal terms. Savings and time deposits rose by one third, given the incentive of interest rates on deposits that were positive in real terms, owing to the deregulation of interest rates in 1990. Interest rates on deposits remained around $22 \%$ per annum.

Inflation surged in El Salvador during the second half of 1992. After the success of a stabilization policy, that had cut the rate of price variations almost in half during 1991 $(10 \%)$, that rate rose to close to $17 \%$ over the 12-month period ending in November 1992 , thereby returning to a level similar to that of the two preceding years. Although the cause of the jump in prices was a readjustment of public tariffs and the application of a new law governing the value added tax during the second half of the year, the rise in inflation was fed by a persistent fiscal imbalance of around $5 \%$ of GDP and an overexpansion of the money supply. The inflow of external resources continued to be an important factor in monetary expansion as well as in the financing of private consumer spending. In this regard, families received a higher amount of unrequited private transfers from abroad than that received for the export of goods. Finally, during the course of the year, interest rates were totally deregulated and the sale to the public of the shares of three commercial banks was completed.

Inflation rose slightly in Guatemala, from $10 \%$ to $12 \%$. Prices remained stable for the second year in a row, after having risen by a record high of almost $60 \%$ during 1990 , supported by a slight variation in the nominal exchange rate under a system of mini-devaluations with a float within a band, and with a prudent fiscal management that showed a slight deficit representing $0.5 \%$ of GDP. However, lower prices for the country's main exports, the dynamic behaviour of imports and the relaxing of monetary policy which led to a drop in interest rates gave rise to an active demand for foreign currency, and this resulted in a loss of international reserves of around US $\$ 120$ million (a little less than $10 \%$ of the value of merchandise exports). At the beginning of the year, the monetary authorities announced their decision to maintain the price of the dollar within a band of $4 \%$. Since the steady demand for foreign currency continued to put pressure on the exchange rate, the Central Bank increased the dollar supply from US $\$ 4$ million to US\$11 million per day during the last two months of 1992. Fiscal policy was also more expansionary than the year before, when a surplus of around $0.5 \%$ of GDP was achieved. Although current income grew to $9.5 \%$ of GDP in the context of a higher growth rate over the last seven years spending increased more rapidly, from $8.6 \%$ to $10 \%$ of GDP. The rise in public wages was a key factor in this behaviour, since actual investment amounted to only $40 \%$ of what was programmed. A fiscal reform was approved during the year that extended the coverage of the value added tax and ratified a law unifying tariffs in the Central American subregion. Moderate inflation and higher wages led to an increase in real average wages for the first time in several years.

The Dominican Republic consolidated the price stabilization it had achieved the year before. Inflation in the 12-month period ending in October stood at $6 \%$, slightly higher than the 4\% in 1991 and in strong contrast with the $100 \%$ recorded two years before. Monthly inflation rates were negative during the first quarter and less than $1 \%$ per annum during most of the year. The stability of domestic prices continued to be supported by tight fiscal and monetary policies and a slow rise in the nominal exchange rate. The central Government increased its surplus to close to $3 \%$ of GDP, owing to greater fiscal pressure. Income from domestic activity increased as a result of a rise in the sales tax from $6 \%$ to $8 \%$ and a significant tax hike on petroleum. The average tariff on imports effectively collected also rose considerably, because of higher appraised values. Although capital expenditures expanded significantly, current expenditures did so only moderately.

The favourable monetary conditions stemming from the surplus-producing management of the central Government made it possible to provide more credit to the private sector, especially to commerce and agriculture. Unlike the year before, the flow of international reserves, even though positive, did not exert significant pressure on monetary policy. Local currency devalued slowly during the first half of the year, but by the end of the year the price of the dollar was at more or less the same level as in late 1991.

Panama maintained its slight variation in prices at around $1 \%$ per annum, with a somewhat better although still deficit-producing fiscal performance. The Caribbean countries, finally, behaved in varying ways. Haiti, affected by severe political disturbances, saw its inflation rate rise from $7 \%$ to $18 \%$, which reversed the progress made the year before. Also, Trinidad and Tobago regressed in its anti-inflationary policy, returning to a level of $8 \%$ per annum (compared to $2 \%$ in 1991). Barbados, in turn, continued the same unstable behaviour it displayed in recent years; this time inflation decelerated to $6 \%$. Jamaica recorded the best progress in this sub-region. After the flare-up of inflation last year, to $77 \%$, a successtul stabilization policy reduced the annual 
variation in consumer prices to only $14 \%$ in September.

\section{The external sector}

\section{a) The international context}

In 1992 the economies of the industrialized countries converged towards similar rates of sluggish growth or deceleration, which overall represented a weak revival of the level of activity following their poor performance in 1991, when almost all of them suffered a recession or grew very little. Only the United States and Canada showed early signs of recovery, while most of the other developed economies slackened their pace of expansion. A number of disturbing events took place on the international scene, such as turbulence in European exchange markets, a decline in the Japanese stock market, tensions generated by the GATT negotiations on agricultural products and the further crumbling of the economies of eastern Europe and the former Soviet Union. Because of this situation, Latin American and Caribbean export markets continued to face the sluggish demand for commodities observed the preceding year, with steeper drops in commodity prices and weakened demand for manufactured goods. At the same time, however, the region once again benefited from another fall in international interest rates in dollars, a steady flow of capital from abroad and the dollar's low value in international markets for most of the year.

The industrialized economies' moderate growth rate of $1.5 \%$ was nearly $1 \%$ higher than in 1991, but lower than the 1984-1990 average of $3.5 \%$. This recovery basically reflected events in the United States economy, which expanded nearly $2 \%$ after contracting $1 \%$ the preceding year (though with an upward trend in the third quarter). In contrast, Japan's economic slowdown worsened, as GDP grew by only $2 \%$ in the first half of 1992 , or $2.5 \%$ less than in 1991 and well below its performance in recent years; this decline was accentuated in the third quarter. Germany, after growing rapidly in early 1991, lost momentum under the stringent monetary policy put into effect to control inflationary pressures generated by a high fiscal deficit and a wage hike. The German economy's difficulties affected the rest of the European countries, keeping the European Economic Community's overall growth rate between $1 \%$ and $1.5 \%$.

The volume of world trade expanded nearly $5 \%$, which was an improvement over the preceding year's low rate of somewhat over $2 \%$ but far below the annual average of over $7 \%$ recorded in 1987-1989. In addition, the world-wide supply of some agricultural products was disproportionate to depressed demand, protracting the decline of commodity prices in recent years. World prices of cotton, bananas, cacao, coffee, beef, copper, iron ore and lead deteriorated, in some cases quite severely. On the other hand, the prices of wheat, tin and zinc increased (see table 13), while oil prices hovered around an average similar to that of 1991.

In world financial markets, short-term interest rates in most of the industrialized countries tended to fall in 1992 because of the economic recession and the low rate of inflation. In particular, interest rates in the United States continued to drop, influenced by a monetary policy which was designed to reverse the economic recession. Interest rates in dollars thus reached one of their lowest levels in the past 30 years. Conversely, monetary policy in Germany and Italy focused on relieving inflationary pressures, and raised interest rates considerably. In the second half of the year, the European countries' monetary and financial situation became charged with tension owing to the problems encountered by in attempting to harmonize the rates of inflation and interest of the countries of the European Monetary System (EMS). This led to a highly unstable situation in exchange markets that obliged Italy and Great Britain to abandon EMS temporarily, devalued the Spanish peseta and the Portuguese escudo and exerted great pressure on the French franc, which was ultimately relieved by the intensive intervention of the German and French monetary authorities.

\section{b) Foreign trade and the terms of trade}

The value of the region's merchandise exports grew moderately (4\%), reaching US $\$ 126$ billion, which represented a slight renewal of dynamism after the preceding year's minor contraction. However, the 1992 expansion was very modest compared to that of 1987-1990, when foreign sales rose at an average rate of $12 \%$ a year solely by virtue of a volume increase of over $6 \%$. Unit values fell more than $2 \%$ in 1992 because of the adverse conditions prevailing in foreign markets (see table 10).

The export performance of the countries of the region was quite mixed: five countries Brazil, Chile, Costa Rica, Guatemala and Honduras recorded substantial increases (between $6 \%$ and 19\%); another three Argentina, Ecuador and Uruguay had moderate uses; four others El Salvador, Mexico, Panama and Peru showed stagnant export levels; and the remaining seven economies for which information was available Bolivia, Colombia, the
Dominican Republic, Haiti, Nicaragua, Paraguay and Venezuela experienced a fall in the value of exports, between $10 \%$ and $26 \%$ in five of them. The value of exports from oil-exporting countries declined $2 \%$, with a drop in unit value of nearly $3 \%$, mainly because of lower average hydrocarbon prices and a volume increase of less than $1 \%$. Non-oil-exporting countries, in contrast, saw the value of their exports rise $9 \%$ owing to the higher volumes exported, while the unit value dipped slightly (2\%).

The value of the oil-exporting countries' foreign sales fell from US\$56.5 billion in 1991 to US $\$ 55.4$ billion in 1992 . Venezuela suffered a $6 \%$ decline, owing essentially to the significantly reduced unit value of oil, which was a delayed reflection of falling international oil prices. That, in turn, was a direct consequence of the gradual normalization of the international hydrocarbons market after the ending of the Gulf conflict and the industrialized countries' recession. Sales of products other than oil remained stagnant because of decreased fiscal incentives, a reorientation of sales towards the growing domestic market and a drop in the real exchange rate. In Mexico, the value of exports rose only slightly (1\%) as a result of the sluggishness of the industrialized economies, the gradual overvaluation of the peso, stagnant oil exports and various problems in the export of other commodities. Foreign sales of products other than oil rose by just under $3 \%$, whereas they had grown $13 \%$ the preceding year; among these, manufactured goods expanded $7 \%$, compared to nearly $16 \%$ in 1991 . Moreover, adverse weather conditions caused a $14 \%$ drop in agricultural exports, while persistently depressed world prices pulled extractive products down dramatically $(-37 \%)$. Colombia's exports shrank $6 \%$ owing to problems in the coffee market and reduced export subsidies. The fall in the value of exports affected all sectors except oil and oil products. The value of foreign coffee sales plunged because of the fall in international coffee prices. Non-traditional exports, which had shown great dynamism in the past few years, contracted in $1992(-6 \%)$, probably in response to the elimination of the subsidies which had fostered them. In Peru, the increased volume of exports narrowly offset the drop in their value. This weak performance reflected the low exchange rate and the impact of poor weather conditions in the case of agricultural and fishing exports. In Ecuador, exports rose moderately $(4 \%)$ thanks to the robust increase in oil shipments. However, exports of fish, shrimp and bananas, which had flourished in recent years, stagnated because of the climatic conditions affecting 
the country. In Bolivia, the value of exports plummeted $(-18 \%)$ as a result of reductions in both unit value and volume (see table 10).

The South American non-oil-exporting countries, with the exception of Paraguay, saw the value of their exports rise. Brazil's foreign sales expanded nearly $13 \%$, reaching a record high for the country of US $\$ 35.6$ billion, which made up for the poor results of the preceding two years. The phenomenon reflected, in particular, a large jump in Brazil's exports to the Latin American integration Association (ALADI) countries (of over $50 \%$ ), especially Argentina, where its exports were bolstered by that country's liberalization policy and a favourable exchange rate in relation to the Argentine peso. Chile's exports grew faster, increasing nearly $12 \%$ mainly because of the performance of products other than copper; these grew $15 \%$ in spite of a $4 \%$ real appreciation of the local currency in 1992 and a $6 \%$ appreciation in 1991. Copper exports were hurt by an additional cut in their international price. The value of Argentina's exports rose 6\% owing to a strong expansion of wheat and maize exports in terms of both volume and unit value. In contrast, oilseed exports fell, while the remaining export categories grew slightly. The maintenance of the volumes exported at a time of recovery in the domestic economy and exchange-rate appreciation suggests that the increases of recent years are unlikely to suffer reverses; on the other hand, sales of industrial goods show no signs of significant expansion, except in the case of automobile sales to Brazil. Uruguay's exports grew nearly 5\%, thanks to the partial recovery of traditional products (especially beef and wool), whose value increased $10 \%$ after dropping $25 \%$ during 1990. Non-traditional exports continued to rise moderately, favoured by an advantageous exchange rate with Argentina. Paraguay's exports declined 13\% because of plunging cotton sales $(-24 \%)$, which were affected by a fall in the product's international price. Soybean exports also contracted $(-20 \%)$, but soybean derivatives oil and meal showed strong increases, reaching unprecedented levels.

The Central American and Caribbean countries (for which information was available) showed a $3 \%$ increase in the value of exports, despite another drop in the price of coffee one of the most important products sold abroad by these countries and problems with cotton exports. In Costa Rica, the value of merchandise exports grew $19 \%$ because of the extraordinary expansion of non-traditional products, including the inbond assembly industry, melons and garments, and of traditional products such as bananas, which had not yet suffered the effects of Europe's new trade barriers to imports of that product.
Coffee exports, however, slid $26 \%$ as the lower international price was accompanied by decreased volume. Guatemala's exports rose by over $6 \%$ in spite of the dip in the prices of its main products. In E Salvador, the value of exports stagnated because of a severe contraction of foreign coffee sales, while non-traditional exports increased $13 \%$, especially through exports to other countries of the Central American Common Market. Merchandise exports from Honduras rose nearly $10 \%$, with a $20 \%$ hike in the volume exported, which more than offset the steep drop in prices. The recovery of banana exports following the declining trend of the preceding four years, and the continued boom in shrimp and lobster shipments, contributed to this impressive performance. The value of Nicaragua's exports declined $12 \%$ as a result of plummeting prices for the main export commodities, which completely wiped out the gains made through the higher export volumes of some products, especially coffee and beef. In Panama, exports of national commodities, dominated by bananas, grew slightly and with no significant changes in their composition. Meanwhile, re-exports from the Colón Free Zone declined slightly. The value of exports from the Dominican Republic slumped again $(-10 \%)$ because of a nearly universal decline in traditional products, especially ferronickel and raw sugar, the two most important export categories.

For the third year in a row, the value of imports of goods to Latin America and the Caribbean increased notably (18\%), reaching US\$132 billion; the oil-exporting countries showed a higher increase $(21 \%)$, while the rate for non-oil-exporting countries was $16 \%$. Import growth in both groups of countries was solely the result of higher volume, since unit values varied little (about $1 \%$ ). Imports rose in 16 of the 19 countries for which information was available, declining only in Brazil, Haiti and Paraguay. Although this expansion was widespread, Mexico was responsible for $40 \%$ of the total regional increase, boosting its imports by US $\$ 8$ billion, while another $30 \%$ was attributable to Argentina, with an increase of US $\$ 5.7$ billion. Also significant were the increases recorded in Chile, Colombia, Costa Rica, the Dominican Republic, Guatemala and Venezuela, where imports grew over $20 \%$ (see table 11):

Imports to the oil-exporting countries expanded from US $\$ 59.3$ billion to US $\$ 71.6$ billion. Mexico's imports continued their dizzying rise $(21 \%)$ for the fifth year in a row, reaching US $\$ 46$ billion, nearly four times the 1987 figure. Notable were the large increases (of nearly $40 \%$ ) in imports of capital and consumer goods. However, foreign purchases slowed somewhat in the second half of the year owing to the decelerated growth of economic activity and the effects of administrative measures intended to prevent unfair trade practices and to enforce compliance with national quality standards. Venezuela's imports again grew significantly (25\%), amounting to US $\$ 12.7$ billion. This expansion was influenced by the robust increase in economic activity, an appreciated real exchange rate and the tariff reductions introduced under the trade liberalization programme initiated in 1989, which went into its third phase in May 1991 with a reduction of the maximum tariff from $50 \%$ to $40 \%$. In Colombia, imports rose by US\$1 billion, to a total of US\$5.6 billion, as a result of its liberalization policy, which had deepened in the course of the preceding year. Peru's imports increased nearly $14 \%$ despite its economic recession, reflecting the effects of trade liberalization and a real appreciation of the local currency. Imports to Ecuador expanded slightly (just over $2 \%$ ). Foreign purchases, especially of durable consumer goods, industrial capital goods and transport equipment, had grown significantly until August (12\%). However, as might have been expected, imports fell off abruptly under the new economic programme, which, inter alia, introduced a $35 \%$ depreciation in the official exchange rate. Bolivia's imports went up $10 \%$ because of an investment boom, continued growth in the level of activity and more capital inflows with which to finance these increased foreign purchases.

In the South American non-oil-exporting countries, merchandise imports rose from US\$39 billion to US\$45.6 billion. In Argentina, as a result of the vigorous expansion of domestic demand, the liberalization policy and an appreciating local currency, imports skyrocketed once again $(77 \%)$ in all categories of goods. The import policy was adjusted somewhat in October, when, together with increased export drawbacks, the across-the-board rate imposed on all merchandise introduced into the country was raised from $3 \%$ to $10 \%$, creating a hike in the de facto exchange rate; however, its impact was not reflected in foreign purchases in 1992. Chile's imports were highly dynamic (25\%), spurred by the economy's robust growth, an abundant inflow of capital and the gradual appreciation of the local currency. In particular, imports of consumer and capital goods shot up nearly $40 \%$. Imports also climbed rapidly in Uruguay $(11 \%)$ reflecting sizeable increases in almost all categories except oil. It should be noted that the accelerated expansion observed in purchases of consumer goods may include, along with burgeoning automobile imports, articles purchased by visitors residing in Argentina. In Brazil, imports declined $4 \%$ because of the country's severe economic recession, mainly in 
industrial activity, and the depreciation of the local currency. The value of foreign purchases also fell in Paraguay $(-6 \%)$ owing to a reduced inflow of capital and fewer re-exports to neighbouring countries. To date, its liberalization efforts including the lowering and simplification of tariffs beginning in July, has not markedly affected imports.

In the Central American and Caribbean countries (for which information was available) the value of imports rose $12 \%$. With the exception of Haiti, which was affected by an international trade embargo, all the countries in this group boosted their foreign purchases, though to very different degrees. Imports were particularly dynamic in Costa Rica (30\%) as a result of liberalization measures, which gained momentum in 1992 with tariff reductions and the elimination of surcharges and advance deposits. Guatemala's foreign purchases also grew significantly $(25 \%)$, with a $44 \%$ increase in imports of consumer goods. This expansion was influenced by the liberalization policy introduced in 1990, which was intensified in 1991 with the elimination of various import permits. In the Dominican Republic, economic reactivation and trade liberalization brought about a strong upsurge in merchandise imports $(20 \%)$, whose financing was facilitated by a large inflow of capital. EI Salvador's imports grew more moderately $(11 \%)$ and were concentrated mainly in capital goods for transport and construction and in consumer goods. The value of imports to Honduras rose $4 \%$ owing to the country's economic revival; increases were seen in all categories except oil and oil products, which declined. In Panama, imports for domestic activity grew nearly $10 \%$, reflecting the economy's normalization after the 1987-1989 crisis. In contrast, imports to the Colón Free Zone (for re-export) stagnated following their notable expansion in 1991. Nicaragua's imports rose $6 \%$; the most dynamic categories were consumer goods and capital and intermediate goods for industry, as well as building materials.

The terms of trade for the region as a whole fell more than $3 \%$, owing mainly to the dwindling unit value of exports, which caused that of imports to rise only $1 \%$. This decline, when added to earlier decreases (particularly the sharp reductions of 1981-1982 and 1985-1986), brought Latin America and the Caribbean's terms of trade to $28 \%$ below their 1980 level. The downturn affected all the countries in the region except Argentina. The oil-exporting countries' terms of trade deteriorated $4 \%$; of this group, Bolivia and Venezuela were hardest hit, while Mexico suffered only a slight decline. For the South American non-oil-exporting countries, the terms of trade slumped $2 \%$. This decline reached $9 \%$ in Paraguay, primarily because of lower cotton prices, and $4 \%$ in Chile as a result of fallir $\mathrm{g}$ copper prices. The erosion of Brazil's terms of trade $(-2 \%)$ was exclusively due to the decline in export prices. On the other hand, the increase in the unit values of Argentina's exports, particularly wheat, boosted the terms of trade, though very modestly. All the Central American and Caribbean countries suffered punishing setbacks in their terms of trade, which plummeted $16 \%$ in the case of Nicaragua. This phenomenon resulted primarily from the tumbling prices of this group of countries' main export products, including coffee, cotton and ferronickel (see table 12).

The purchasing power of the region's exports defined as export volume adjusted by the evolution of the terms of trade rose only $3 \%$, which was less than half the growth of volume, owing to the erosive effects of deteriorating terms of trade (see table 13). However, the pattern reflected by this outcome in the oil-exporting countries differed from that in the rest of the region's economies. In the former, falling international oil prices pulled down the purchasing power of exports by over $3 \%$. In Venezuela, this decline was nearly $8 \%$, since export volume remained stagnant because of the oil market's limitations, while the terms of trade slipped significantly. A similar reduction of the purchasing power of exports took place in Colombia, owing basically to lower coffee prices and a reduction of non-traditional export volume. Bolivia, in turn, suffered a $20 \%$ slump attributable to the severe decline of both export volumes and the terms of trade. Peru's reduction was nearly $1 \%$, reflecting the deterioration of its terms of trade. The purchasing power of Mexico's exports stagnated, as the slight increase in export volumes was offset by the dip in the terms of trade. Ecuador was the only country in this group whose exports grew in purchasing power, thanks to larger oil shipments, which more than made up for the effect of the decline in the terms of trade. Outstanding among the non-oil-exporting countries were Brazil, Chile and Costa Rica, whose exports increased in purchasing power by $13 \%$, $10 \%$ and $18 \%$, respectively, owing solely to the higher volumes exported. In contrast, the Dominican Republic, Haiti, Nicaragua and Paraguay suffered a severe decline because the effect of their eroding terms of trade was compounded by a substantial decrease in export volumes (see table 13).

\section{c) The current account, its financing and the overall balance of payments}

Since the rise in the value of exports was more modest than that of imports, the merchandise trade balance became negative, representing a turnaround of US $\$ 16$ billion compared to the preceding year. The trade balance had been positive since 1983 and had risen vigorously in subsequent years, reaching almost US\$30 billion in 1990. In 1991, with the explosion of imports and the stagnation of exports, the balance had fallen to less than half that figure. As these trends continued in 1992, the surplus not only disappeared but slid into a deficit of US $\$ 5.9$ billion. This turnaround in the region's trade balance was primarily a consequence of the increase of nearly US\$8 billion in Mexico's trade deficit; the change of sign in Argentina, which went from a surplus of US $\$ 4$ billion to a deficit of close to US $\$ 400$ million; and the reduction of Venezuela's positive balance by about US $\$ 3.4$ billion. Surpluses also declined in Colombia (US $\$ 1.5$ billion) and Chile (US\$800 million), while Uruguay's modest surplus became a US $\$ 200$ million deficit. Deficits grew in Costa Rica, the Dominican Republic (US\$420 million), El Salvador, Guatemala (US\$340 million), Nicaragua, Panama, Paraguay and Peru (US\$600 million). Conversely, trade surplus increases were recorded in Brazil (almost US\$5 billion) and Ecuador, while Honduras considerably reduced its trade deficit.

Latin American and Caribbean net payments of profits and interest fell by US $\$ 1.4$ billion, amounting to US\$29.4 billion. This decrease benefited a number of countries: Argentina, with a reduction of US\$1.4 billion; Brazil (US\$1 billion); Colombia (US\$400 million); Ecuador (US\$100 million); and Uruguay (US $\$ 40$ million). Outlays of this type grew in all of the Central American and Caribbean countries except El Salvador and Haiti.

The region's lower net payments for factor services reflected the net effect of contrary trends. On the one hand, interest due on the external debt fell in practically all of the countries, owing primarily to the decline in international interest rates in dollars. On the other hand, remittances of profits on foreign direct investment increased significantly, partially offsetting the attenuated world-wide flow of interest payments.

As the deterioration in the terms of trade carried considerably more weight than the reduction in the amounts due for profits and interest, the region's current-account deficit rose from US\$19.4 billion to US\$32.7 billion, widening the expansion that had begun the preceding year. However, excluding Brazil, which achieved a large surplus in 1992, the deficit figure for the remaining economies of the region more than doubled, rising from US $\$ 18.4$ billion to US $\$ 39$ billion (see table 15). 
These increases in current-account deficits or reductions of surpluses were attributable to similar patterns in most of the countries of the region. The oil-exporting countries, with the exception of Ecuador, saw a substantial increase in their deficits which brought the total negative balance for this group from US $\$ 12.9$ billion to US $\$ 27.3$ billion. Mexico's deficit again grew dramatically, from US $\$ 13.5$ billion to US\$20.7 billion. Venezuela, which in 1991 had seen its surplus dwindle to less than US\$2 billion, recorded a deficit of US\$3.7 billion in 1992. Colombia's US\$2.6 billion surplus fell to just over US\$1 billion. Meanwhile, Bolivia's deficit increased by US\$200 million, Peru's remained unchanged and Ecuador's decreased by over US\$100 million. The South American non-oil-exporting countries reduced their current-account deficit from US $\$ 4.1$ billion to US $\$ 1.8$ billion, though this development was almost entirely the result of the dramatic turnaround in Brazil's current account, since the other countries in this group saw their deficits rise. Notable among the latter group are Argentina, whose deficit increased by over US $\$ 4$ billion, and Chile, whose US\$160 million deficit swelled to US\$800 million. Paraguay's deficit also grew, while Uruguay's surplus almost disappeared. In contrast, the strong expansion of Brazil's trade surplus for goods and the decrease in net payments of profits and interest turned that country's US\$1 billion current-account deficit into a healthy surplus of US\$6.5 billion. The deficit for the Central American and Caribbean countries as a whole increased by US $\$ 1.6$ billion, and affected all the members of this group.

The region's capital account again recorded a highly positive balance of US $\$ 57$ billion, which was almost $50 \%$ more than the already high level reached the preceding year. Nevertheless, this increase was essentially attributable to Argentina and Brazil, whose capital inflows surged by US $\$ 3.7$ billion and US\$8.8 billion, respectively; and, to a lesser degree, to increased capital flows to Chile, Mexico and Venezuela. The oil-exporting countries, which in 1991 had already had a highly positive capital-account balance of nearly US $\$ 27$ billion, recorded a balance of US $\$ 31.6$ billion in 1992 . Three fourths of these flows went to Mexico, which received US $\$ 23$ billion, compared to over US $\$ 21$ billion the preceding year. With the exception of Peru, the other oil-exporting countries enjoyed significant increases in capital flows; even Colombia's capital-account balance, which had been negative in 1991, became positive. Capital flows to South American non-oil-exporting countries more than doubled their 1991 level. Particularly notable were the capital flows to Brazil, which rose from US\$1.2 billion to US\$10 billion, though impressive increases were also seen in Argentina (from US $\$ 5.3$ billion to US $\$ 9.3$ billion) and Chile (from US\$1.4 billion to US\$2.7 billion). In contrast, capital flows to Paraguay dried up considerably. Large capital inflows were also recorded in the Central American and Caribbean countries (US $\$ 3.8$ billion), although this level was virtually the same as that witnessed in 1991.

In Argentina, low international interest rates in dollars continued to encourage a copious inflow of foreign capital, including the repatriation of funds which residents had kept in other financial markets, with the result that the positive capital-account balance was nearly $70 \%$ higher than the already soaring 1991 level. Brazil's capital inflows skyrocketed from US $\$ 1.2$ billion to US $\$ 10$ billion because of the growing differential observed throughout 1992 between foreign and domestic interest rates; the latter reached $5 \%$ a month in real terms. The flow of capital was also encouraged by the success of Brazil's external debt negotiations with its creditors. These resources were channelled through lines of credit for foreign trade (especially exports), bonds and short- and medium-term commercial paper of Brazilian enterprises, and stock-market investments on the part of foreign funds through the So Paulo and Rio de Janeiro stock exchanges. Beginning in July, the political crisis slowed the inflow of capital; even the stock exchanges recorded a net outflow of foreign funds. As a result of this situation, capital inflows in the second half of the year amounted to somewhat over US $\$ 1$ billion, contrasting with the over US\$8 billion received in the first half.

Mexico's capital account recorded a large inflow of foreign resources for the fourth year in a row, though at a slower rate of growth than in 1991 . About $60 \%$ of these resources went into portfolio investments (stocks and bonds), while one fifth went into direct investment. Also notable were the improvement in Mexico's country-risk rating and the reopening of some segments of the international capital market. Up to September, the federal Government and certain State enterprises and agencies raised nearly US\$1.2 bilition in resources through the placement of bonds in United States and European markets. The private sector's foreign indebtedness continued to grow; some enterprises managed to place issues of securities in foreign stock markets, although the perception of signs of saturation led them to limit these placements and to raise the instruments' real returns. The net inflow of capital to Chile remained high, doubling the preceding year's level in spite of the restrictive measures adopted during the year to prevent such inflows, which were hindering the management of monetary policy and exerting pressure for a revaluation of the local currency. Venezuela also received a larger inflow of capital, though it was based on greater indeotedness on the part of PDVSA, the State petroleum enterprise. However, inflows through private investments declined (from US\$1.4 billion in 1991 to only US\$100 million in 1992), especially in the second half of 1992, because of the slowness of the privatization process and uncertainty about the permanence of the economic model.

Since its net inflow of capital was $70 \%$ higher than its current-account deficit, Latin America and the Caribbean's balance of payments was positive in the amount of US\$24 billion an improvement over the preceding year's balance, which had already been very high. This development meant that the international reserves of most of the countries of the region swelled significantly, and shrank in only five countries. However, most of this increase corresponded to the US\$16.5 billion hike in Brazil's reserves, which contrasted with the modest increases recorded in previous years. Mexico's international reserves expanded by US $\$ 2.5$ billion, Argentina's and Chile's by about US $\$ 2$ billion and Colombia's by US\$1.5 billion. Nevertheless, Mexico's accumulation of reserves had decidedly slowed, amounting to less than one third of the increase recorded in 1991. A significant growth in reserves was also noted in Ecuador (US\$600 million), Peru (US\$500 million), Costa Rica and Uruguay (US\$150 million), Panama and the Dominican Republic (about US $\$ 60$ million). In contrast, Venezuela's international reserves decreased by US\$1.6 billion, though they remained at a comfortable level of over 10 months' worth of imports. Paraguay saw its reserves diminish by nearly US $\$ 500$ million, while Guatemala's fell by US $\$ 120$ million, Nicaragua's, by US $\$ 60$ million and EI Salvador's, by US\$50 million.

The net transfer of financial resources to Latin America and the Caribbean was positive for the second year in a row, after nine years of large net transfers abroad. Moreover, the net amount of financial transfers received in the region was three times the 1991 figure, reaching $17 \%$ of the value of exports of goods and services (see table 16). The large increase in net transfers of resources primarily reflected the flood of capital and, to a much lesser extent, the attenuated flow of payments of profits and interest. Also, contrary to the preceding year's improvement, which corresponded almost entirely to only three countries, a larger number of countries experienced a positive net inflow of 
resources in 1992. In the oil-exporting countries, the positive transfer observed in 1991 swelled to nearly $24 \%$ of the value of exports of goods and services. Within this group, only Colombia continued to record a negative net transfer of resources. The non-oil-exporting countries, wich until 1991 had witnessed negative trinsfers, experienced a dramatic turnaround, going from a negative net transfer of somewhat over $7 \%$ to a positive net transfer of resources close to $12 \%$ of the value of their exports of goods and services. Especially noteworthy was the case of Brazil, where a negative net transfer of US\$8 billion turned into a positive one of US $\$ 1.8$ billion. Also, Argentina went from a near-zero net transfer to a positive one of US $\$ 4.8$ billion. Chile was also the scene of a turnaround, recording a positive transfer of US\$1 billion after experiencing a negative one of US $\$ 400$ million in 1991. In the countries of Central America and the Caribbean, which traditionally have received net transfers from abroad, the amount of the latter held steady.

\section{External debt}

\section{a) Main trends}

After stagnating in 1991, the region's external debt rose $2 \%$ in 1992, reaching a total of US\$451 billion towards year's end (see table 19). Various factors led to this expansion, notably new bond placements abroad (which amounted to US $\$ 10$ billion in late 1992), official credits, a proliferation of short-term credit operations and accumulated arrears in interest payments. The two main contractionary factors were the dollar's recent rise in international exchange markets which reduced the dollar value of the debt denominated in other currencies and the various debt-reduction schemes implemented in many countries of the region. Lastly, the debt's growth was somewhat restrained by the dynamism of non-debt-related capital movements, especially foreign direct and indirect investment (in equity capital), as well as the flow of resources to short-term deposits in the region's banking systems, reflecting in part a repatriation of capital.

Whereas 14 countries in the region had recorded an absolute reduction of the amount of their foreign obligations in 1991, in 1992 only four countries Argentina, the Dominican Republic, Paraguay and Honduras experienced such a decrease (see table 19).

Although Argentina managed to consolidate its access to the international capital market by placing US\$1.5 billion in bonds abroad, its total debt declined for the third year in a row, this time by $3 \%$. The decrease was due both to the effect of an ambitious privatization programme, under which promissory notes for the public debt were accepted as a means of payment, and to a Brady Plan accord on the reduction of banli debt.

The marked reduction $(-21 \%)$ in the balance of Paraguay's external debt basically reflected the Government's partial elimination of its debt-servicing arrears. The Dominican Republic, for its part, reduced the balance of its obligations by $2 \%$ through the buy-back of commercial debt paper on the secondary market. The $0.4 \%$ decline in Honduras's overall obligations was a result of debt-reduction exercises with official lenders.

Among the countries whose foreign debt grew in 1992, the highest growth rate $(8 \%)$ was recorded in Chile, and largely reflected the expansion of short-term credit operations related to trade (see table 19). Nicaragua also experienced a notable increase in external obligations $(7 \%)$ as a consequence of new official credits and accumulated arrears in interest payments to certain Governments and to private banks. Venezuela's external liabilities rose $6 \%$, owing basically to public-sector transactions, particularly by the State-owned petroleum enterprise, which placed nearly US $\$ 1$ billion in bonds on the international market during the first half of the year. El Salvador's external debt expanded almost $5 \%$ as it contracted additional official credits (which had shown a net decrease in 1991). The increase of over $4 \%$ in Brazil's external debt reflected public and private enterprises' active participation in international bond markets (where they placed US\$3 billion worth of obligations), as well as the expansion of short-term credit lines (especially to finance exports) and the accumulation of more arrears in interest payments on the debt with private banks.

\section{b) The debt burden}

Indicators of the region's external debt burden continued to fall in 1992, prolonging the improving trend observed in recent years. Thus, the coefficient reflecting interest due on the external debt as a per cent of the region's total exports of goods and services fell for the sixth year in a row, to $20 \%$; this was the lowest percentage recorded since 1980 and was exactly half the maximum coefficient recorded in 1982, the year the external-payments crisis broke out (see table 20). However, even with such a dramatic decrease, interest payments still absorbed an excessive proportion of the region's export earnings, and therefore efforts must continue to reduce the service of the debt.

In 1992, the decline of the region's interest/exports coefficient was basically attributable to the fall in interest payments, since foreign sales were relatively sluggish and contributed only marginally to the lower ratio. The contraction of interest payments from US $\$ 33$ billion in 1991 to US $\$ 30$ billion in 1992 was due in part to the reduction of private bank and official debt, but basically reflected the marked fall in international interest rates in dollars, especially the short-term rates; for example, the LIBOR fell below $4 \%$ in late 1992, compared to $6 \%$ one year earlier and over $8 \%$ in 1990 .

Nevertheless, two factors helped attenuate the impact of this considerable reduction in international interest rates on the region's interest payments: the prior conversion, under the Brady Plan, of US\$34 billion of floating-rate bank debt into par-value bonds with fixed interest rates that are currently higher than the market rate; and the growing weight of multilateral debt, which carries variable interest rates that are relatively inelastic in the short term with respect to trends in the dollar-based credit market.

In 1992, the ratio of interest to exports of goods and services fell in all but five countries of the region (see table 20). The lower level of interest due on the debt was the main cause of this decline, except in Brazil, Chile, Costa Rica and Honduras, where the upswing in the value of exports was also a decisive factor. In Venezuela, Paraguay and Nicaragua, the ratio increased as a result of higher interest payments and sagging exports; in Haiti, it rose exclusively because of decreased exports, and in the Dominican Republic its growth was due to higher interest payments.

Practically all the countries in the region continued to show interest/export coefficients of over $10 \%$. The lowest ones were recorded in Guatemala $(6 \%)$, Paraguay $(7 \%)$, Costa Rica $(8 \%)$, EI Salvador and Chile $(11 \%)$ and the Dominican Republic (12\%). The highest coefficients were found in Nicaragua $(122 \%)$, Peru (32\%), Argentina $(27 \%)$, Bolivia $(24 \%)$, Brazil $(22 \%)$ and Ecuador (21\%).

While the evolution of the interest/export coefficient has been quite favourable in recent years, the relation between total debt and exports a more structural indicator of the debt burden has fallen relatively little over the same period. In 1992, the latter coefficient was $282 \%$ for the region as a whole, compared to $290 \%$ in 1991 and $310 \%$ in 1989 (see table 21). The 1992 level, though still extraordinarily high, is $34 \%$ less than the peak of $427 \%$ recorded in 1986. Moreover, the coefficient does not reflect the improvement in the structure of debt payments on account of the extension 
of payback periods under various official restructuring exercises.

In 1992 the total debt/export coefficient rose in all of the oil-exporting countries (except Ecuador and Mexico, where it declined) because of the steep drop in the value of their exports, combined with higher external indebtedness (see table 21). In contrast, the coefficient fell in all of the non-oil-exporting countries except Nicaragua, Haiti and El Salvador, where it again rose markedly. In general, the declines mainly reflected a very modest expansion, and in a few cases even a contraction, of external debt; the only exceptions were Chile, Brazil, Honduras and Costa Rica, where the main causal factor was the expansion of exports.

Most of the countries still have a debt/export coefficient that exceeds the critical threshold of $200 \%$. The lowest coefficients were observed in Paraguay (86\%), Guatemala (137\%), Chile (150\%), Costa Rica (161\%) and Colombia (195\%). The most onerous proportions were recorded in Nicaragua $(3,394 \%)$, Haiti (563\%), Peru (499\%), Bolivia (469\%), Argentina (382\%) and Ecuador (355\%).

The average price of the region's bank debt on the secondary market rose slightly, from 45 cents in December 1991 to 46 cents in November 1992 (see table 22). The upward trend for some countries in arrears, basically reflected a perception in the market that the authorities were in a better position to renegotiate their debt with creditor banks.

\section{c) Debt renegotiation}

The tendency observed in 1992, by which countries in arrears began to find ways to regularize their debt-servicing, intensified in 1992. This development has reversed Latin America's voluminous accumulation of arrears since 1987, which had brought the balance of interest arrearages to over US $\$ 27$ billion in 1991. With the regularization of payments agreed to during the course of this year, the balance of arrears could fall to about US\$11-12 billion.

In June, Argentina announced that it had agreed with commercial creditor banks on the terms of a Brady accord to reduce the current value of US\$23 billion in debt principal and to regularize the payment of US\$8.6 billion in interest in arrears. The conditions of the accord are noteworthy because of their relative simplicity. Indeed, the Government offered the banks only two options for converting the principal. The first was to swap the old debt, with a $35 \%$ discount, for a bond with a 30 year bullet payment, at an interest rate equal to LIBOR plus $0.81 \%$. The second option was to exchange the debt for a bond of the same value as the original debt, also with a bullet payment of 30 years, but at an interest rate that would gradually increase from $4 \%$ in the first year to $6 \%$ beginning in the seventh year. Unlike most other countries that concluded Brady accords, Argentina offered the banks no options that included new loans (see table 23).

Both bonds carry special cash guarantees. The total amount of the principal is backed up by the Argentine Government's purchase of an equivalent amount of 30-year zero-coupon bonds from the United States Treasury. For the interest, a renewable cash guarantee for 12 months' worth of payments is offered. However, the banks were not given the so-called "recapture clause" present in most other Brady accords, which allows for an increase in the bonds' yield if the debtor country's terms of trade show marked improvement.

The treatment of the US $\$ 8.6$ billion in interest in arrears is less favourable. Argentina agreed to pay US $\$ 400$ million in cash, to convert US\$300 million into fourto six-year zero-coupon bonds, and to convert the remainder into 12-year bonds (with a three-year grace period) at an interest rate equivalent to $0.81 \%$ over LIBOR

Initially, it was assumed that most banks would prefer the second option (the par-value bond), and a $40 \% / 60 \%$ distribution between the two options was anticipated. However, the par-value bond option became more attractive as international interest rates continued to fall, and the actual distribution between the options turned out to be $13 \% / 87 \%$. This unexpectedly strong preference for the par-value bond would have posed serious problems under the initial calculations, since it significantly boosted the cost of the guarantees and, ultimately, the amount of financing Argentina would have to mobilize to provide them. Fortunately, with the backing of some multilateral agencies, which had agreed to finance the guarantees, Argentina managed to convince the banks to reconsider and achieved a final distribution of $35 \% / 65 \%$ between the two options. The agreement was finalized in December, and Argentina became the fifth country in the region to conclude a Brady accord, along with Mexico, Venezuela, Costa Rica and Uruguay.

In July the Argentine Government also concluded a debt-rescheduling agreement with the Paris Club. The payment of about US $\$ 3$ billion one third of the country's total debt with the Club was rescheduled with an amortization period of 15 years, including one year's grace (see table 24).

Also in July, Brazil reached agreement with commercial creditor banks on the terms of reference for a Brady accord that would cover US\$44 billion in principal and about US\$3 billion in interest payments, which have been in arrears since 1991. The agreement also activated a plan which Brazil had drawn up the preceding year with private banks to regularize the payment of US\$7 billion in interest in arrears, accumulated between 1989 and 1990 .

In contrast to Argentina's accord, the Brazilian plan offers numerous options (six) to banks for restructuring the debt principal (see table 23). The first two options are for a discount bond and a par-value bond, respectively, under conditions similar to those contemplated in the Argentine accord. The third option is for a 15-year bond (with a nine-year grace period) at an interest rate that rises gradually from $4 \%$ to $5 \%$ between the first and sixth years, after which it becomes a floating rate equal to $0.81 \%$ over LIBOR beginning in the seventh year. The fourth option provides for the restructured payment of the principal over 18 years (with 10 years' grace) at an interest rate equal to LIBOR plus $0.88 \%$, and an obligation on the banks' part to grant new loans equivalent to $18 \%$ of the converted principal. The fifth option is for a rescheduled 20-year payment period (with 10 years' grace) at an interest rate equal to $0.81 \%$ over LIBOR; it also provides for the capitalization of interest during the first six years if the market rate exceeds certain established levels $14 \%$ in the first and second years, rising gradually to $5 \%$ in the fifth and sixth years). The sixth and final option is for a 20 -year bond (with 10 years' grace) at a fixed interest rate of $8 \%$; like the fifth option, it provides for the capitalization of interest in the first six years if the agreed rate exceeds certain levels (see table 23).

Cash guarantees for the first two options are $100 \%$ for the principal and 12 months (renewable) of interest payments. The only other option that offers a special guarantee is the third one, which supports 12 months' worth of interest payments (see table 23). The Brazilian plan has no recapture clause. Unlike other Brady accords, it allows the special guarantees to enter into force gradually over a two-year period. The Government has the right to cancel the accord if the banks' choices result in a problematic distribution of conversion instruments.

The plan provides for the conversion of arrears accumulated in 1991-1992 (which amount to around US $\$ 3$ billion) into 12-year bonds at an interest rate equal to $0.81 \%$ over LIBOR. In addition, it establishes the 
bases for finalizing an agreement negotiated with the banks in 1991 on the interest arrears accumulated in 1989-1991. That agreement had been a precondition stipulated by the banks for the negotiation of a Brady accord; it required an immediate cash payment of US $\$ 2$ billion and the conversion of the balance (US\$7.2 billion) into bonds once agreement was reached on the terms of a debt-reduction accord under the Brady Plan. These bonds were issued in November 1992, with an amortization period of seven years and an interest rate that will eventually reach $0.81 \%$ over LIBOR (see table 23 ).

It should be noted that the entry into force of this Brady accord requires the prior approval of the Brazilian Congress.

Brazil also signed an agreement to reschedule its debt with the Paris Club, under which US\$11 billion half of its total debt with the Club will be paid over a 13-year amortization period, including a two-year grace period. The country will have to make sizable payments to the Club in 1992 and 1993, totalling over US\$4 billion. Furthermore, the Brazilian Government must deposit into Switzerland's Bank for International Settlements an amount of 180 million special drawing rights to guarantee the payment of interest under this agreement (see table 24).

In July, Bolivia agreed in principle to regularize the conditions of payment of US $\$ 185$ million in bank debt. This amount represents obligations that remained in arrears after some lenders refused to participate in two large debt-buyback operations initiated by the Bolivian Government in previous years. As part of this new attempt at regularization, three options were offered: i) a direct buyback at 16 cents on the dollar, financed with grants (inter alia from the World Bank's International Development Association); ii) a 30-year bond whose yield is linked to international tin prices; and iii) a social and environmental policy programme offering various types of debt swaps.

In January, Bolivia became the second Government in the region to benefit from the new, "broadened" Toronto Terms defined by the Paris Club for the poorest countries. These terms allow a $50 \%$ reduction of the present value of the debt corresponding to the consolidation period of the agreement. In this case, the Terms would cover US\$216 million, corresponding to a consolidation period of 18 months (see table 24).

A number of other countries made varying degrees of progress towards the regularization of their situation with creditors. One such country is Paraguay, whose payments to both its Paris Club lenders and commercial banks are in arrears. Currently, its debt-restructuring negotiations are being seriously hindered by the lack of an agreement with the International Monetary Fund (IMF). Nevertheless, in 1992 the Government resumed the servicing of its debt with those creditors, while it sought ways of regularizing the payment of the accumulated arrears. It paid off some arrears with the Paris Club using Central Bank reserves, and effected buybacks of its bank debt in the secondary market. In late 1992, its arrears approached US $\$ 350$ million, one third of which represents interest payments.

Early in the year, Panama had nearly US\$1 billion in interest arrears with banks, and US $\$ 700$ million in arrears with multilateral agencies; in January it paid off the latter with a bridge loan granted by certain Governments. As for its bank debt, the Government is exploring the possibility of negotiating a Brady accord. For its part, Guatemala eliminated its arrears with the World Bank with a bridge loan granted by the United States Agency for International Development (USAID). Its arrears with the Paris Club Governments could be regularized shortly, as a restructuring agreement is expected to be concluded by January 1993. Nicaragua's arrears were reduced when the Russian Government forgave an amount of US\$2.4 billion.

In the Andean region, Peru is apparently on the verge of obtaining the refinancing needed to eliminate its arrears with IMF and the World Bank. Also, the Government has contacted its creditor banks to regularize its payment situation, including interest arrears of over US\$3.5 billion. Ecuador, whose bank interest arrears exceed US $\$ 2$ billion, also contacted its creditor banks to try to solve this problem. In January, the Government rescheduled its debt with the Paris Club under the Houston Terms, defined by the Governments of the Club for lower-middle income countries. The agreement covers US $\$ 350$ million in debt, corresponding to a consolidation period of 12 months; the creditors granted an amortization period of 15 years, with eight years' grace. The Houston Terms also allow for debt-reduction operations, although only of a very limited scope (see table 24).

A significant number of countries effected various types of bilateral debt-reduction operations in 1992, involving mechanisms such as buy-backs on the secondary market, debt-to-equity conversion (inter alia in the context of privatization) and debt-for-nature swaps or swaps for other types of development programmes. In this regard, the largest-scale operation undoubtedly took place in Mexico, whose Government announced that it had bought back on the secondary market, in piecemeal fashion over a number of months, about US\$7 billion in bank debt (nearly $10 \%$ of the total public external debt). 


\section{FIGURES AND TABLES}


Figure 1

LATIN AMERICA: MAIN ECONOMIC INDICATORS
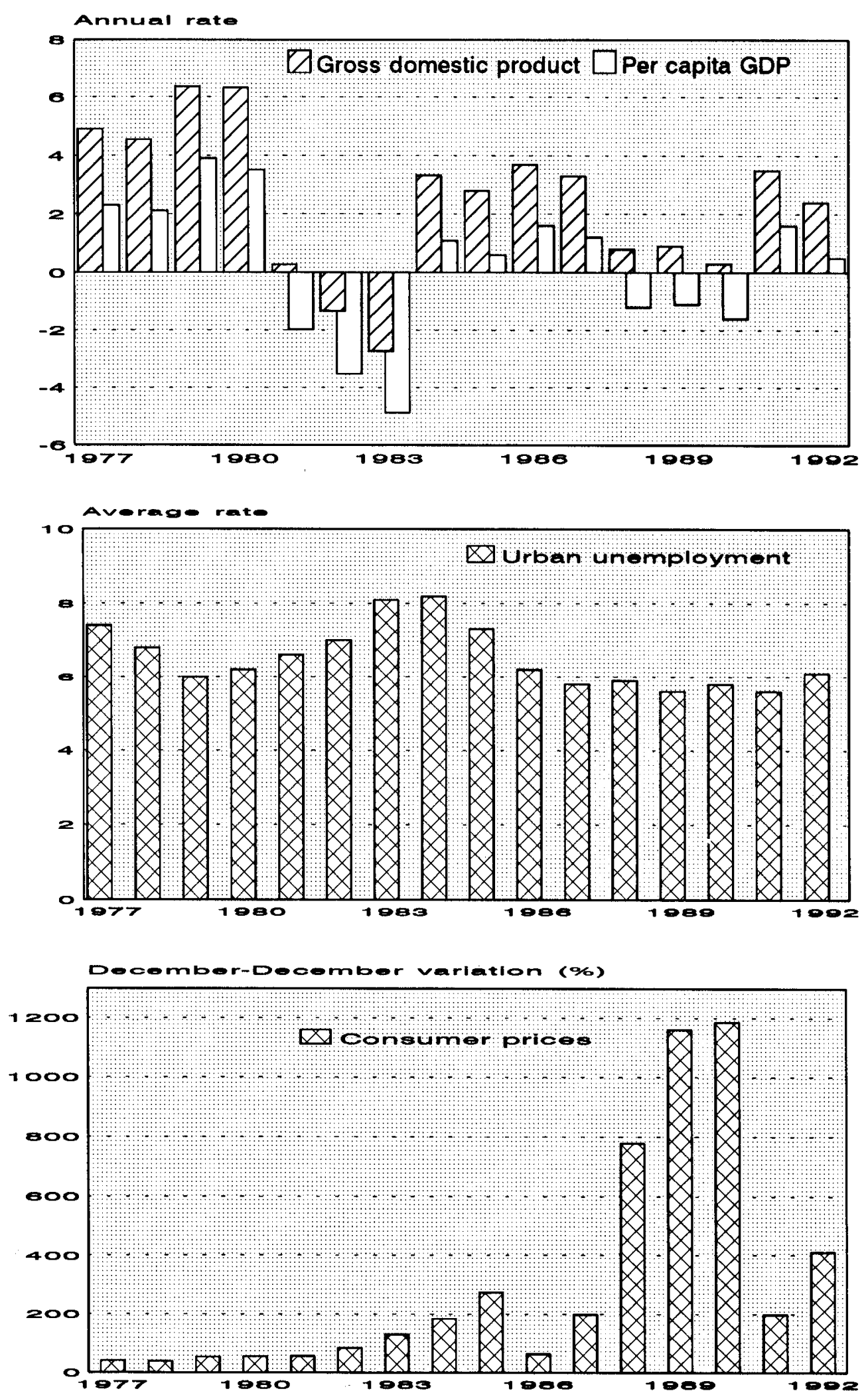
Figure 1 (conclusion)

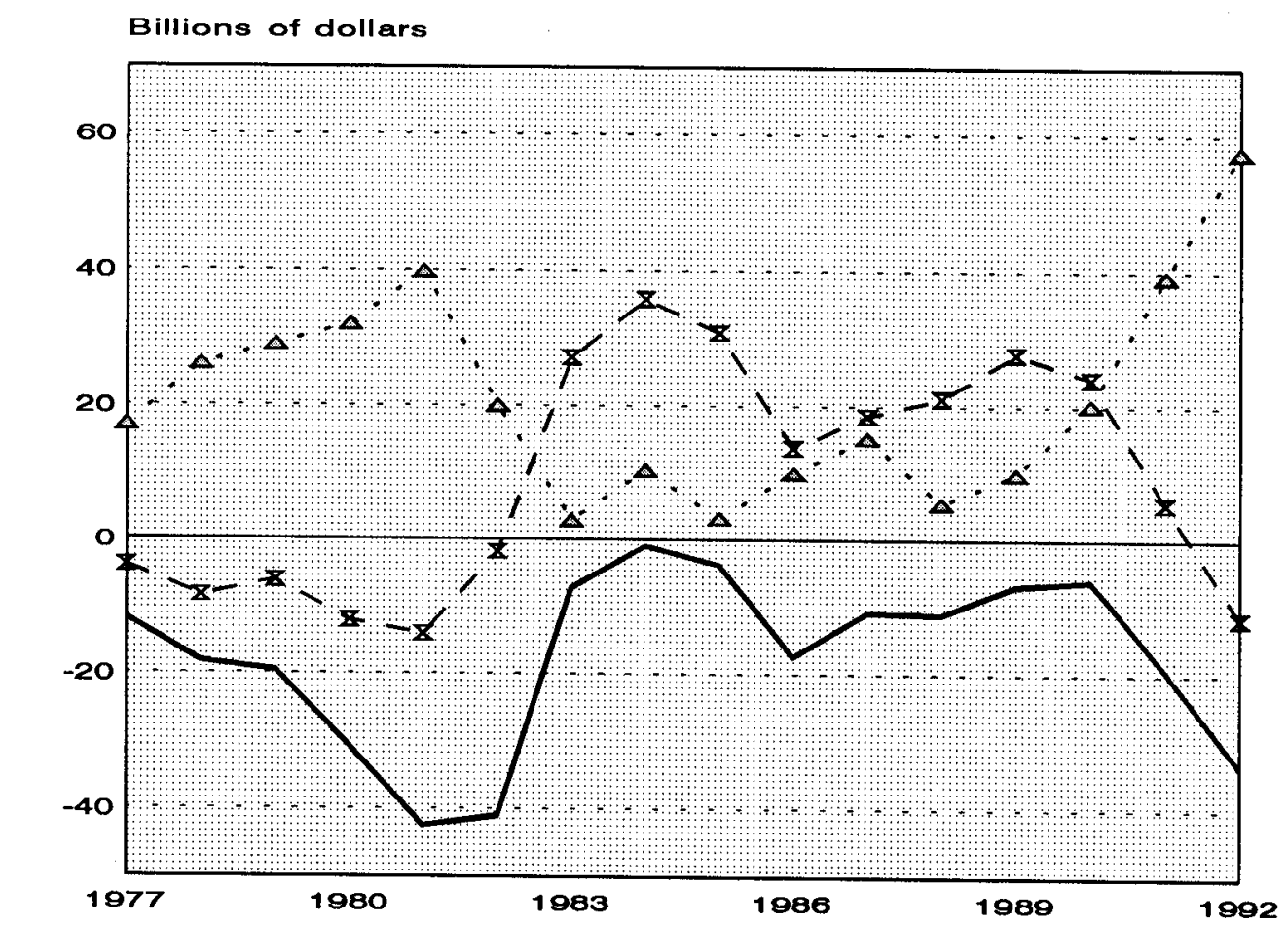

-A- Balance on cap. acc. Z-Trade balance - Balance on curr. acc.

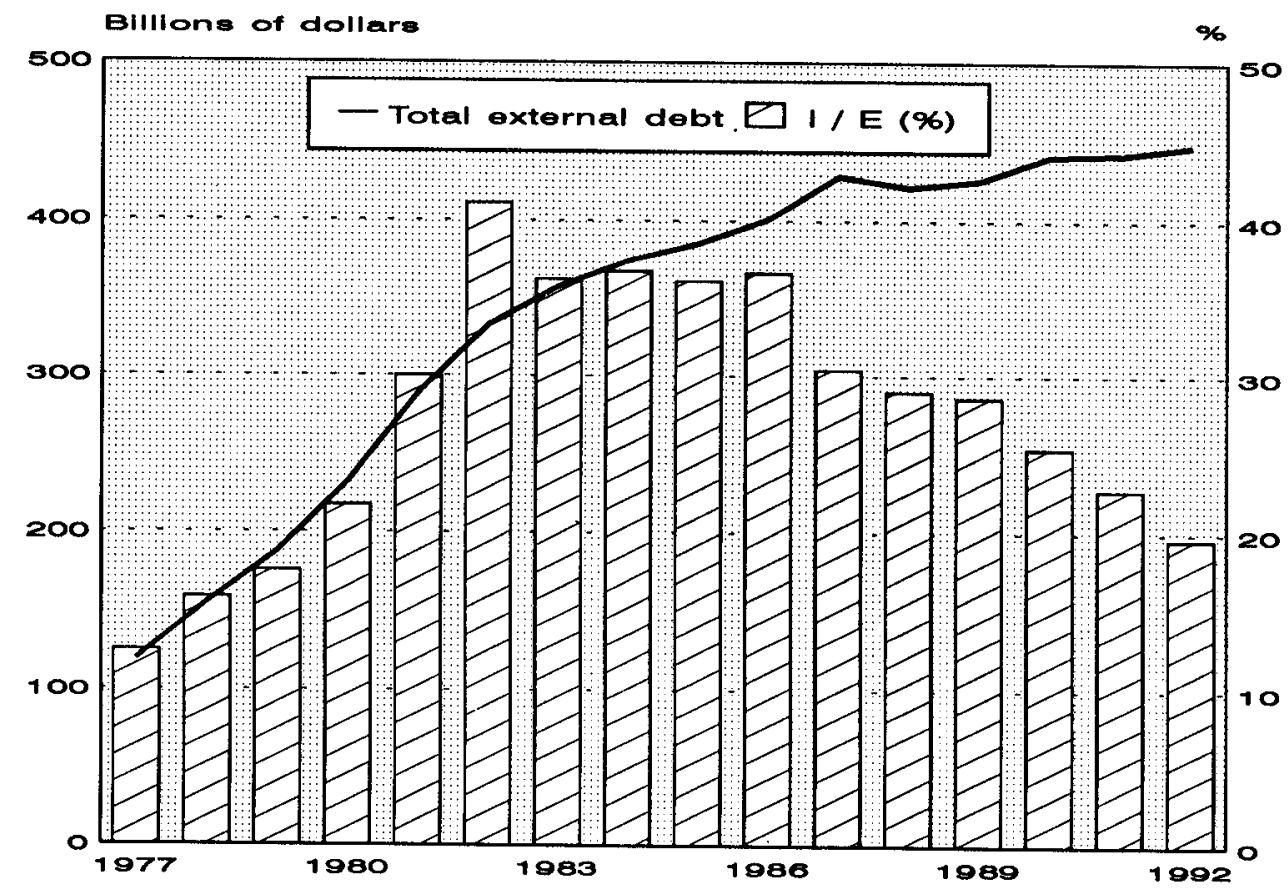

Source: ECLAC, on the basis of official figures. Abbreviations: 1 = Total interest due. E = Exports or goods 
Figure 2

CRUDE OIL PRICES

(Monthly averages)

(Dollars per barrel)

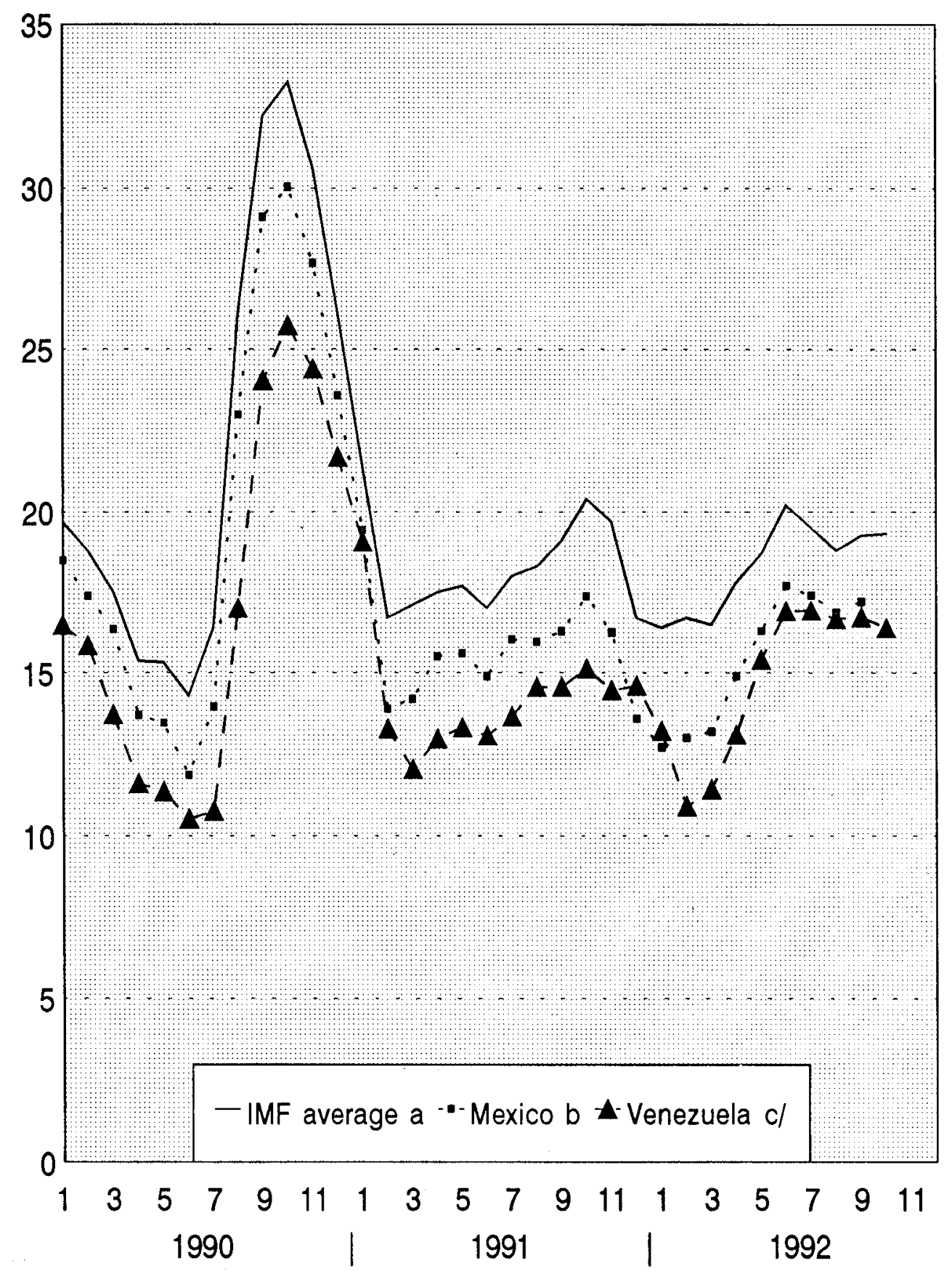

Source: ECLAC, on the basis of figures provided by IMF and Petroleum Intelligence Group, Petroleum Market Intelligence, New York, various issues.

a 'Dubai', 'Brent' (United Kingdom \& 'Alaskan N.Slope'. b Isthmus 34' \& 'Maya 22'. c 'Tía Juana 22. 
LATIN AMERICA AND THE CARIBBEAN (SELECTED COUNTREES): URBAN UNEMPLOYMENT (Annual average rates)
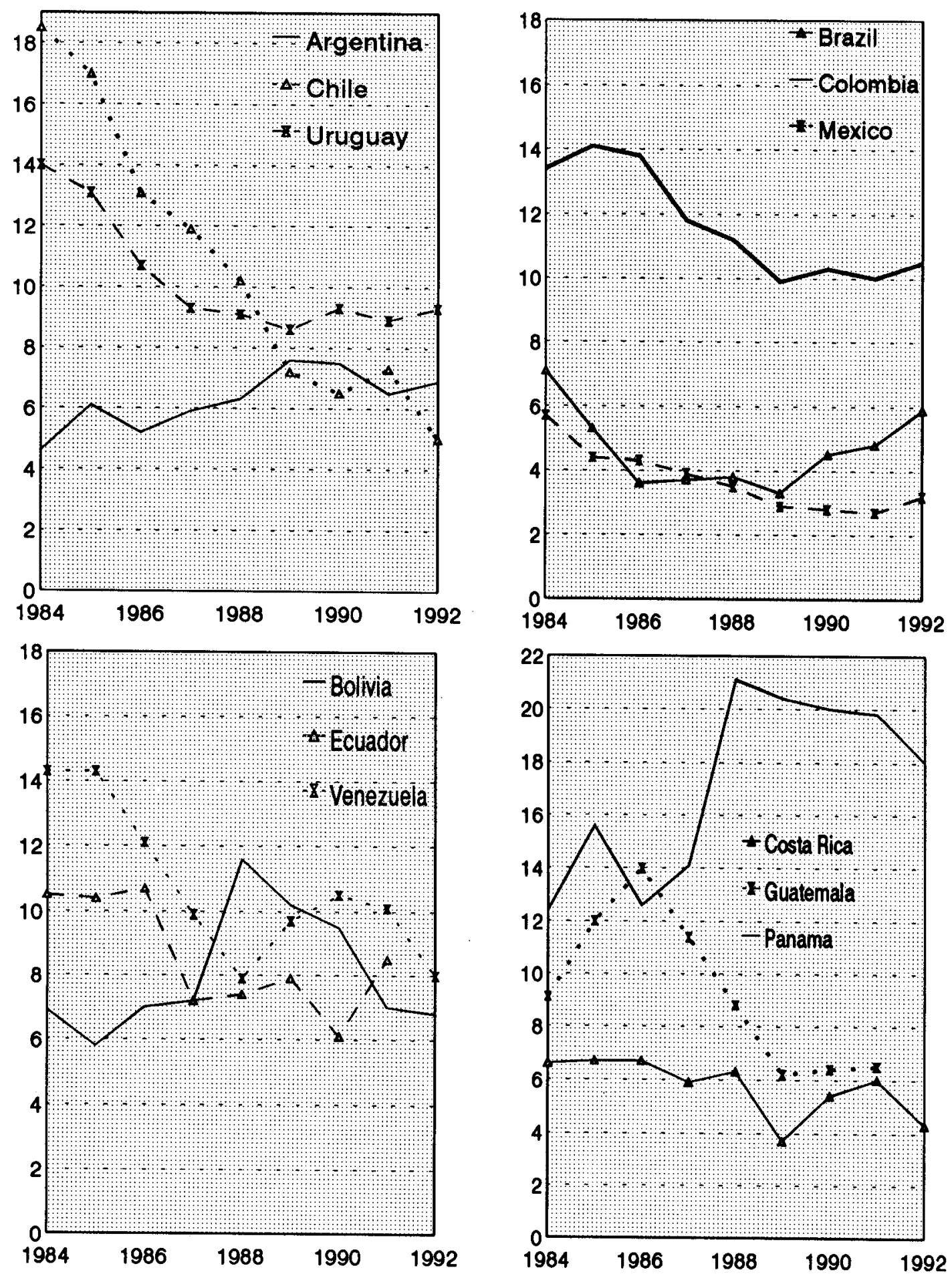

Source: ECLAC, on the basis of official figures. 

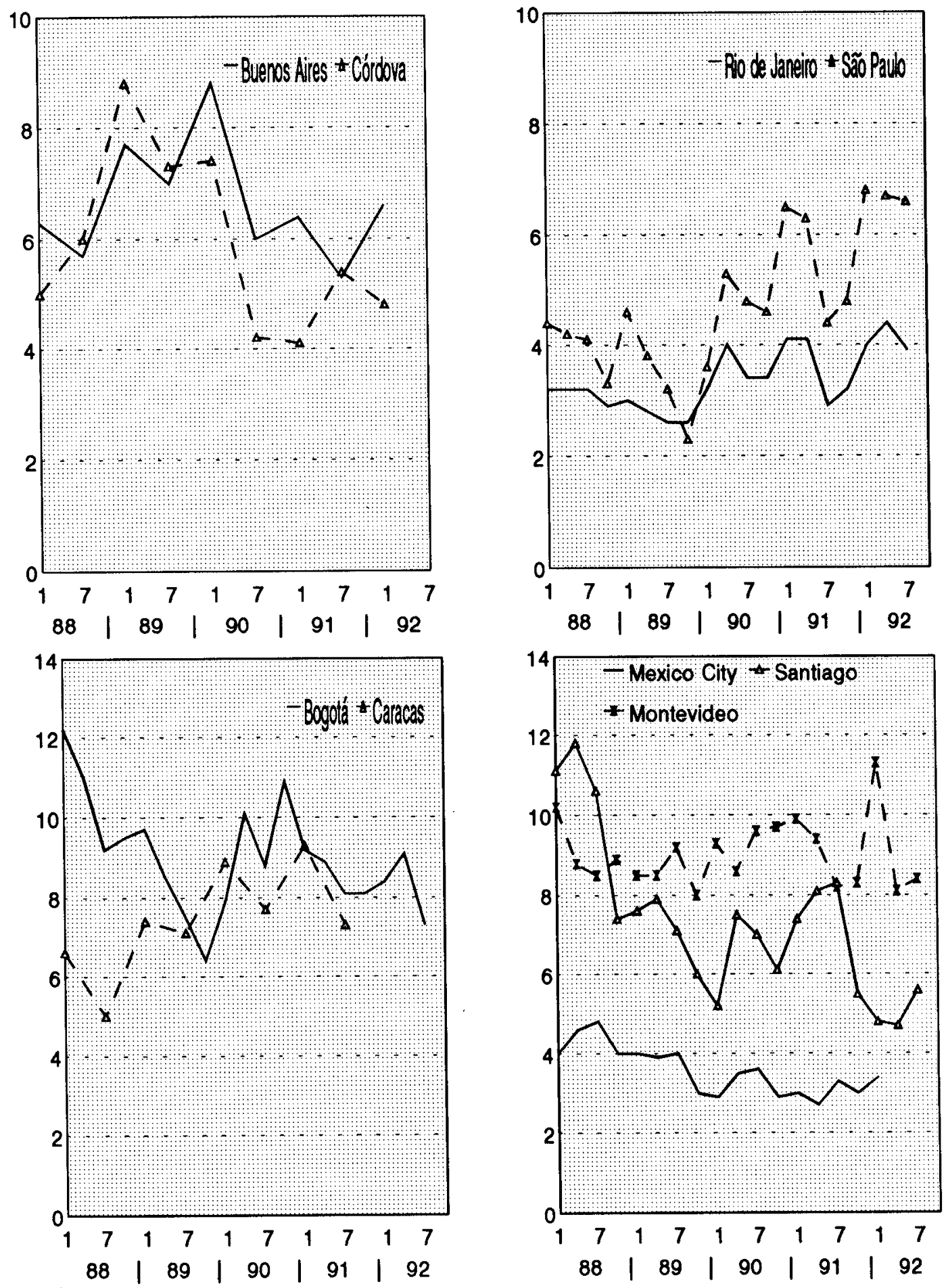

Source: ECLAC, on the basis of official figures. 
Figure 5

LATIN AMERICA (SELECTED COUNTRIES): TWELVE-MONTH VARIATIONS IN CONSUMER PRICE INDEX

Semilogarithmic scale, \%

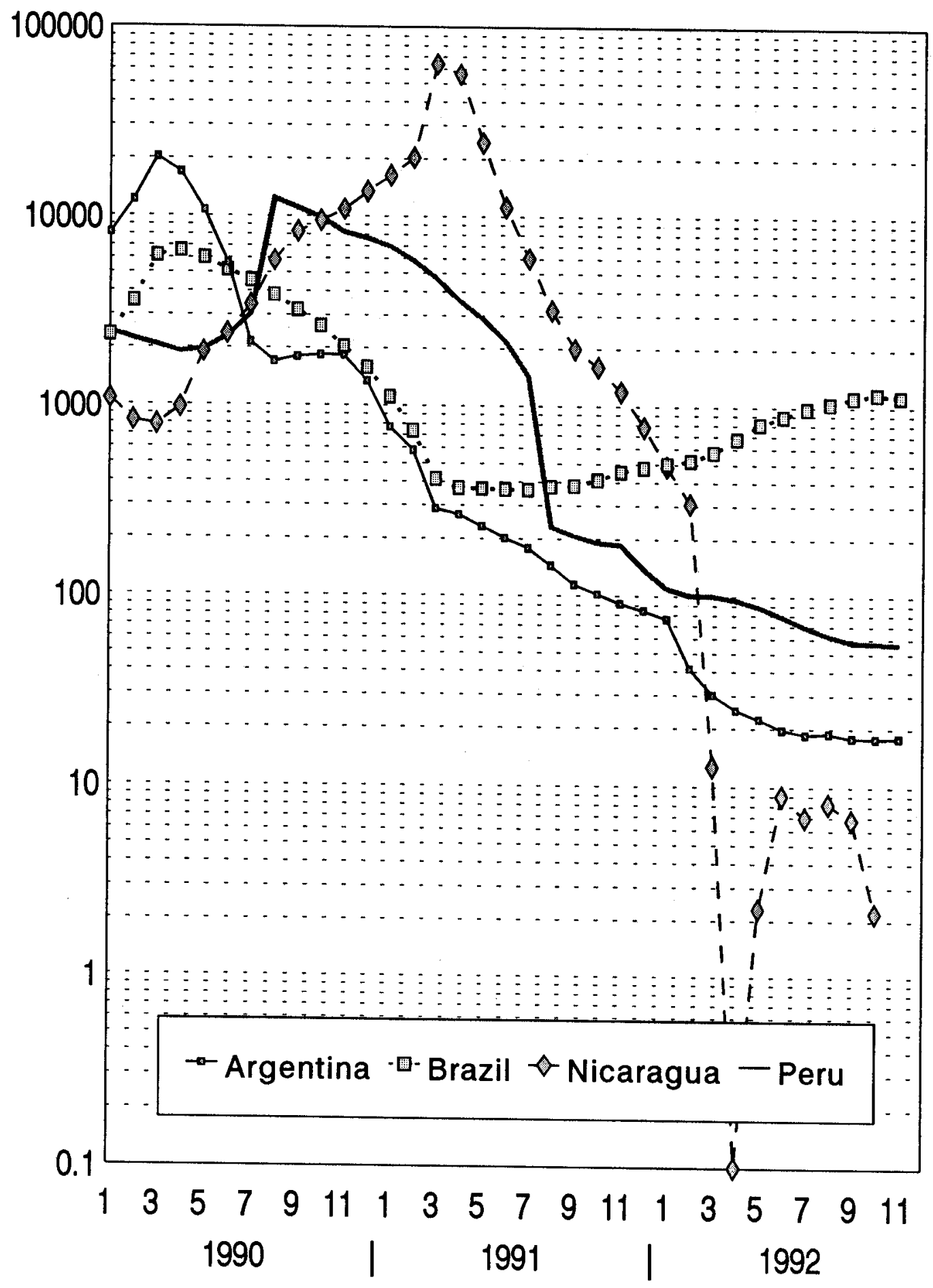

Source: ECLAC, on the basis of official figures. 
Figure 6

LATIN AMERICA (SELECTED COUNTRIES): TWELVE-MONTH VARIATIONS IN CONSUMER PRICE INDEX

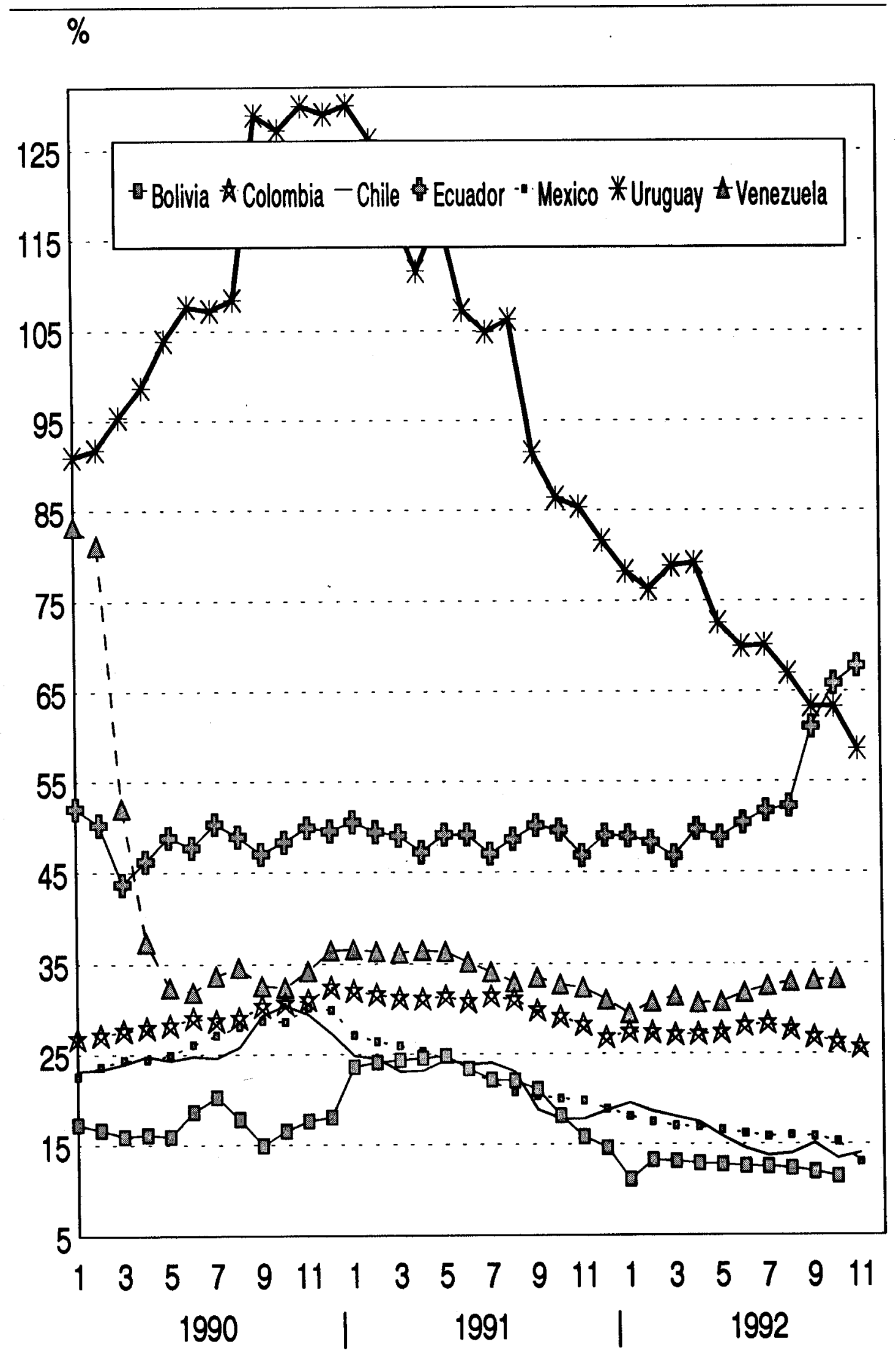

Source: ECLAC, on the basis of official figures. 
Figure 7

LATIN AMERICA (SELECTED COUNTRIES): TWELVE-MONTH VARIATIONS IN CONSUMER PRICE INDEX

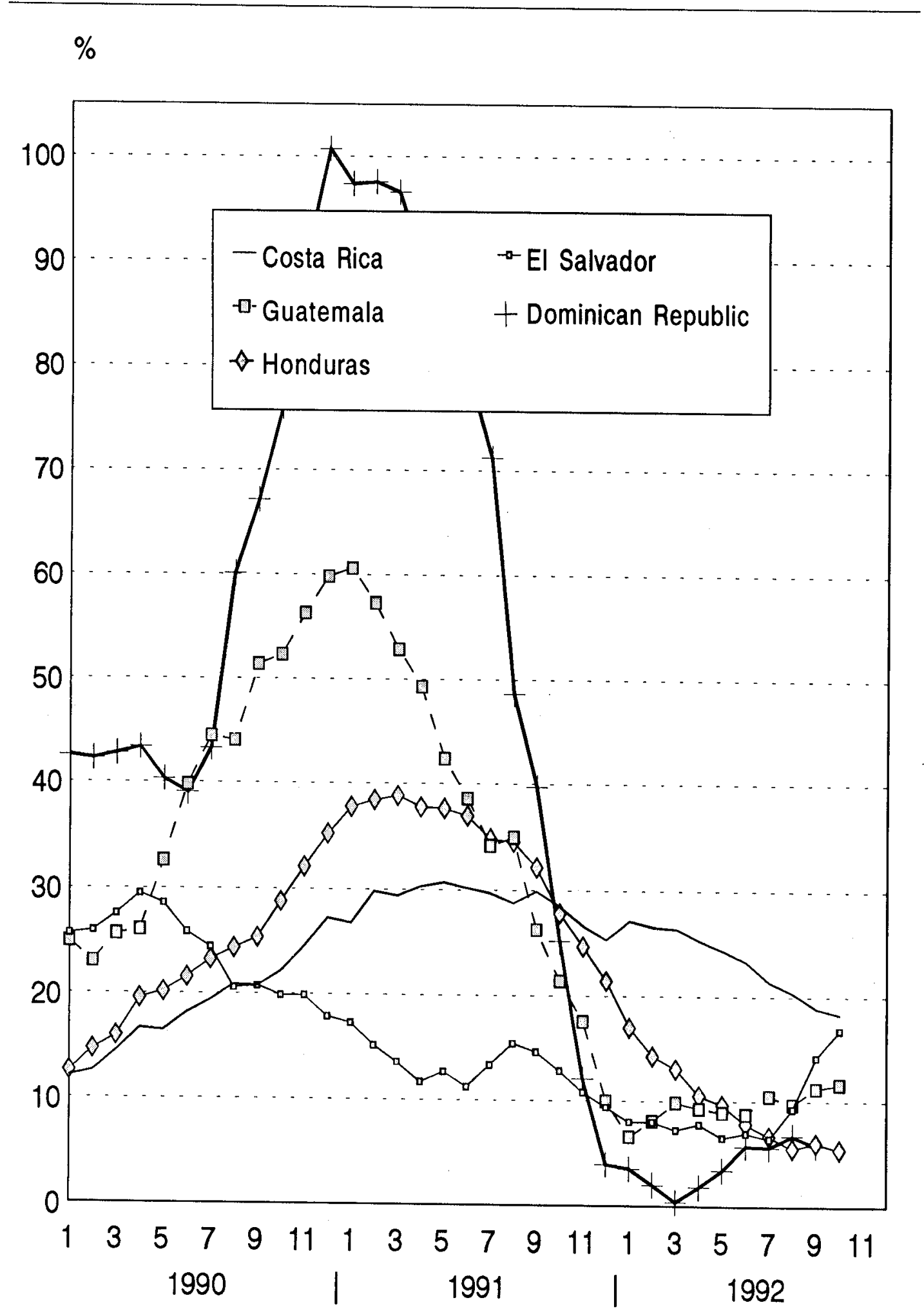

Source: ECLAC, on the basis of official figures. 
Indexes $(1980=100)$

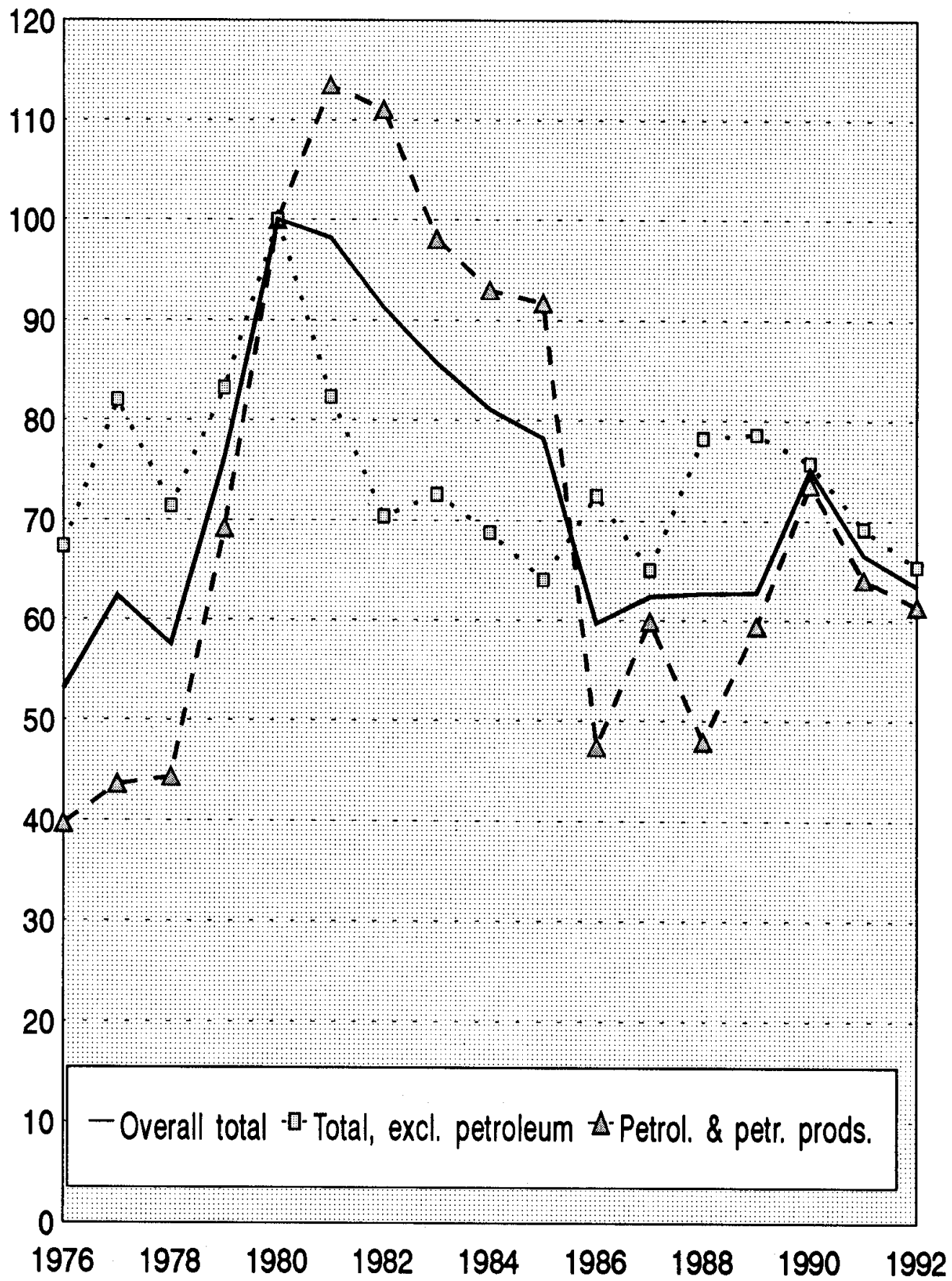

Source: ECLAC. 
Figure 9

LATIN AMERICA AND THE CARIBBEAN: NET INFLOW OF

CAPITAL AND NET TRANSFER OF RESOURCES

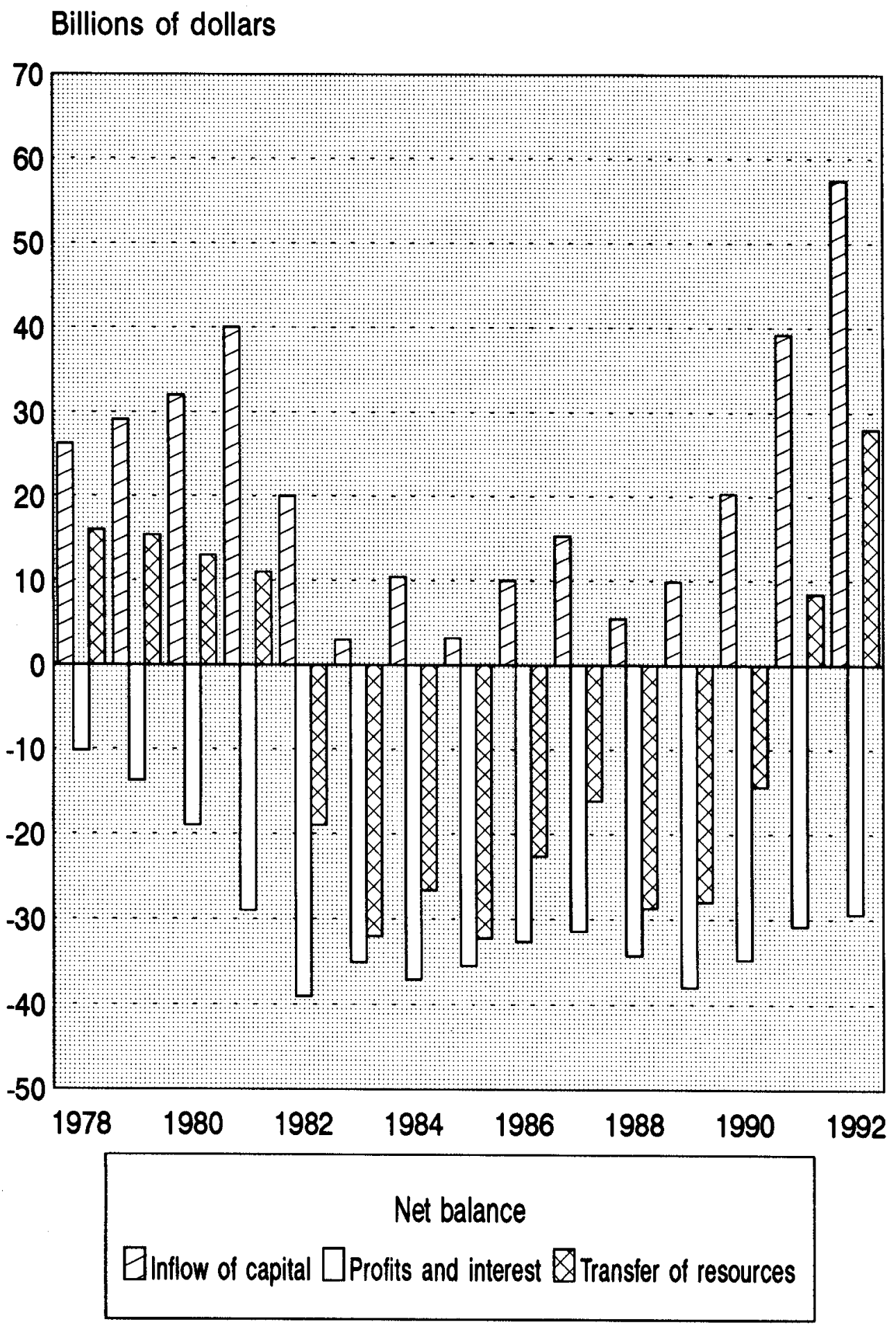

Source: ECLAC, on the basis of figures provided by IMF. 
Figure 10

LATIN AMERICA AND THE CARIBBEAN: TOTAL INTEREST DUE, AS A PERCENTAGE UF EXPORTS OF GOODS AND SERVICES

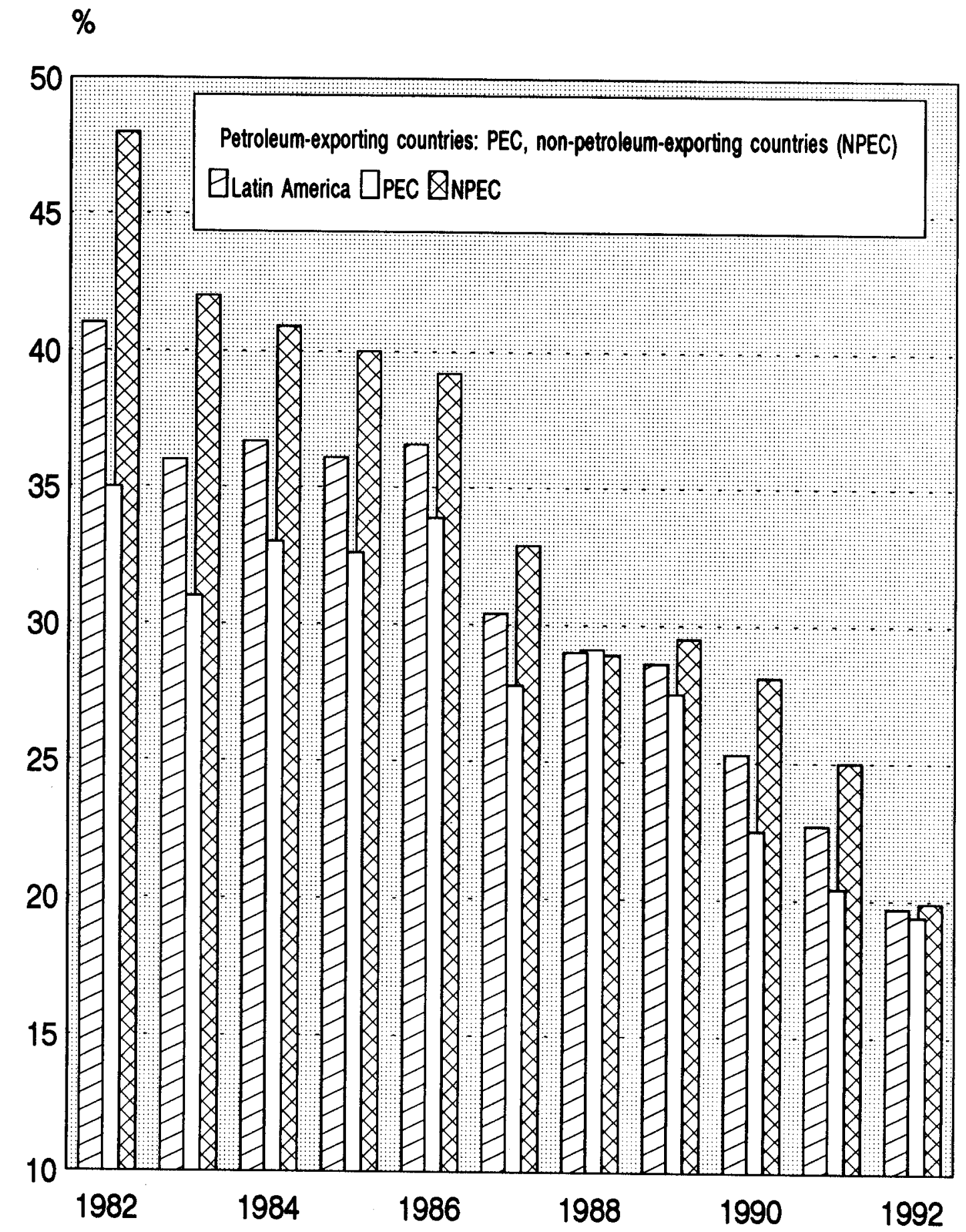

Source: ECLAC, on the basis of official ligures. 
Figure 11

INTERNATIONAL INTEREST RATES

(Percentages)
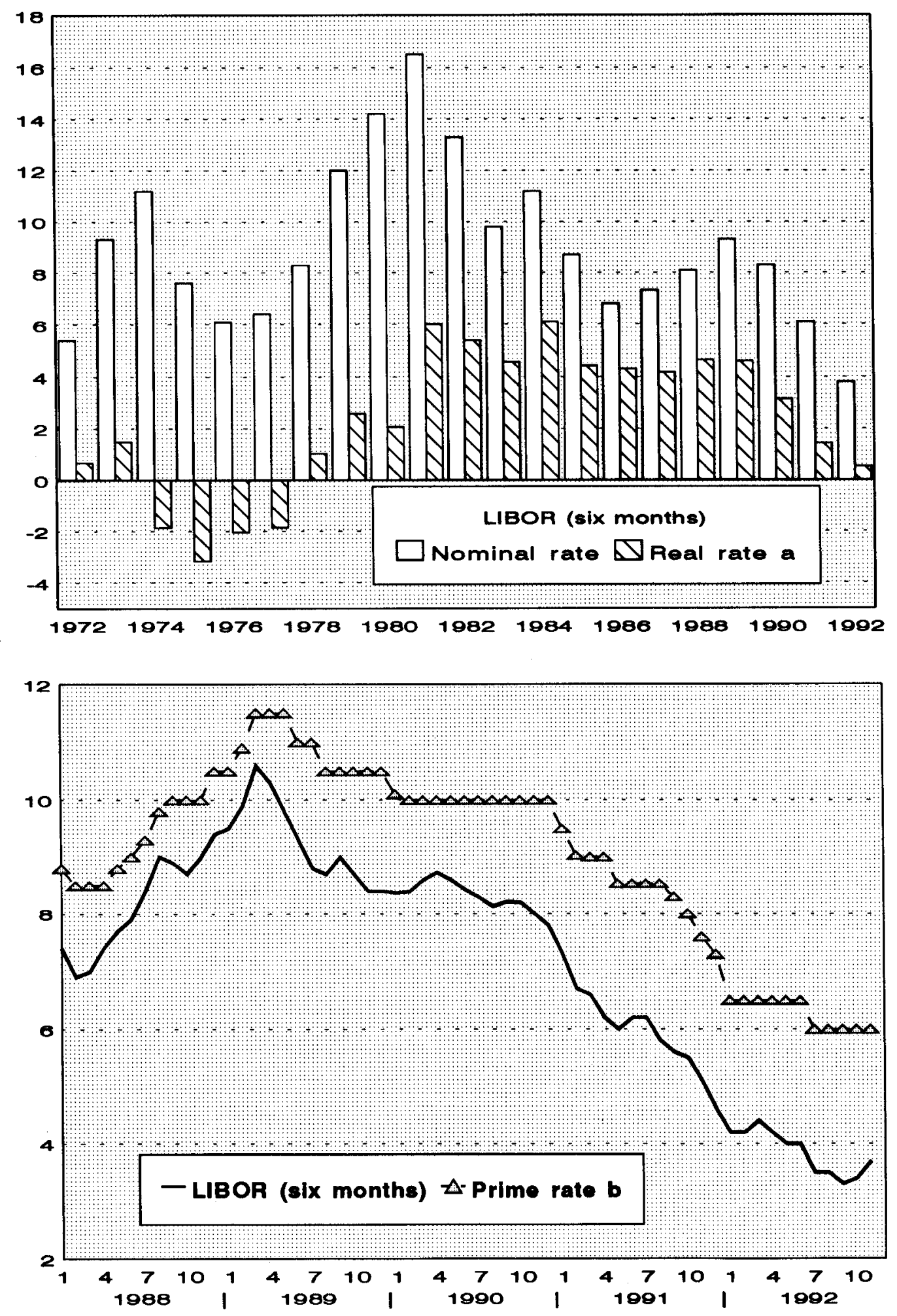

Source: ECLAC, on the basis of flgures provided by IMF.

a Nominal rate deflated by the consumer prioe Index of the Induatrialized countries.

b Preferential rate granted by United States banke to their best oustomers. 
Table 1

LATIN AMERICA AND THE CARIBBEAN: MAIN ECONOMIC INDICATORS ${ }^{\text {a }}$

\begin{tabular}{|c|c|c|c|c|c|c|c|c|}
\hline Indicators & 1985 & 1986 & 1987 & 1988 & 1989 & 1990 & 1991 & $1992^{b}$ \\
\hline $\begin{array}{l}\text { Gross domestic product at market } \\
\text { prices (index, base year } 1980=100 \text { ) }\end{array}$ & 102.6 & 106.4 & 109.9 & 110.8 & 111.7 & 112.0 & 116.0 & 118.8 \\
\hline Population (millions of inhabitants) & 385.2 & 393.3 & 401.4 & 409.5 & 417.6 & 425.7 & 433.7 & 442.0 \\
\hline $\begin{array}{l}\text { Per capita gross domestic product } \\
\text { (index, base year } 1980=100 \text { ) }\end{array}$ & 91.8 & 93.3 & 94.4 & 93.3 & 92.3 & 90.8 & 92.2 & 92.7 \\
\hline \multicolumn{9}{|c|}{ Growth rates } \\
\hline Gross domestic product & 2.8 & 3.7 & 3.3 & 0.8 & 0.9 & 0.3 & 3.5 & 2.4 \\
\hline Per capita gross domestic product & 0.6 & 1.6 & 1.2 & -1.2 & -1.1 & -1.6 & 1.6 & 0.5 \\
\hline Consumer prices $^{c}$ & 280.1 & 64.1 & 208.9 & 773.5 & 1205.0 & 1185.0 & 198.7 & 410.7 \\
\hline Terms of trade (goods) & -4.5 & -11.0 & -0.9 & -0.3 & 1.3 & -0.4 & -5.6 & -3.4 \\
\hline Purchasing power of exports of goods & -4.6 & -11.9 & 7.8 & 8.1 & 4.5 & 5.3 & -1.0 & 3.0 \\
\hline Current value of exports of goods & -5.8 & -15.8 & 14.4 & 13.9 & 10.0 & 9.6 & -0.4 & 4.0 \\
\hline Current value of imports of goods & 0.0 & 2.6 & 12.5 & 14.0 & 6.5 & 15.7 & 18.1 & 18.4 \\
\hline \multicolumn{9}{|c|}{ Billions of dollars } \\
\hline Exports of goods & 92.0 & 77.5 & 88.7 & 101.0 & 111.1 & 121.8 & 121.3 & 126.1 \\
\hline Imports of goods & 58.2 & 59.7 & 67.2 & 76.6 & 81.6 & 94.4 & 111.5 & 132.0 \\
\hline Trade balance (goods) & 33.8 & 17.8 & 21.5 & 24.4 & 29.5 & 27.4 & 9.8 & -5.9 \\
\hline Net payments of profits and interest & 35.3 & 32.6 & 31.5 & 34.3 & 37.9 & 34.7 & 30.9 & 29.6 \\
\hline Balance on current account ${ }^{d}$ & -3.6 & -17.4 & -11.1 & -11.2 & -6.8 & -6.2 & -19.4 & -32.7 \\
\hline Net movement of capital ${ }^{\mathrm{e}}$ & 3.0 & 9.9 & 15.4 & 5.5 & 9.6 & 20.3 & 39.2 & 57.0 \\
\hline Global balance $^{\mathrm{f}}$ & -0.6 & -7.5 & 4.3 & 5.7 & 2.8 & 14.1 & 19.8 & 24.3 \\
\hline Total gross external debt ${ }^{8}$ & 385.1 & 401.0 & 428.1 & 420.9 & 425.4 & 440.9 & 442.6 & 450.9 \\
\hline Net transfer of resources ${ }^{h}$ & -32.2 & -22.6 & -16.1 & -28.7 & -28.0 & -14.4 & 8.4 & 27.4 \\
\hline
\end{tabular}

Source: ECLAC, on the basis of official figures.

a The figures for the gross domestic product and consumer prices refer to the group of countries included in table 2 and table 5 , respectively. The data on the external sector correspond to the 19 countries listed in the table on the balance of payments of Latin America and the Caribbean. $\quad{ }^{b}$ Preliminary estimates, subject to revision. ${ }^{c}$ Variation from December to December.

d Uncludes net unrequited private transfer payments. 'Includes long- and short-term capital, unrequited official transfer payments, and errors and omissions. $\quad$ Corresponds to the variation in international reserves (of opposite sign) plus counterpart items. $\quad$ See the notes to the table "Latin America and the Caribbean: total disbursed external debt".

${ }^{\mathrm{h}}$ Corresponds to net inflow of capital, less net payments of profits and interest. 
Table 2

\section{LATIN AMERICA AND THE CARIBBEAN: GROWTH OF TOTAL GROSS DOMESTIC PRODUCT \\ (Percentages based on values at 1980 prices)}

\begin{tabular}{|c|c|c|c|c|c|c|c|c|c|}
\hline \multirow[b]{3}{*}{$\begin{array}{l}\text { Latin America and } \\
\text { the Caribbean }\end{array}$} & \multicolumn{8}{|c|}{ Average annual rates } & \multirow{2}{*}{$\begin{array}{c}\begin{array}{c}\text { Cumulative } \\
\text { variation }\end{array} \\
1981-1992^{\mathrm{a}}\end{array}$} \\
\hline & 1985 & 1986 & 1987 & 1988 & 1989 & 1990 & 1991 & $1992^{a}$ & \\
\hline & 2.8 & 3.7 & $\mathbf{3 . 3}$ & 0.8 & 0.9 & 0.3 & 3.5 & 2.4 & 18.8 \\
\hline $\begin{array}{l}\text { Oil-exporting } \\
\text { countries } \\
\text { Bolivia } \\
\text { Colombia } \\
\text { Ecuador } \\
\text { Mexico } \\
\text { Peru } \\
\text { Trinidad and Tobago } \\
\text { Venezuela }\end{array}$ & $\begin{array}{r}2.1 \\
-1.0 \\
3.8 \\
3.9 \\
2.6 \\
2.3 \\
-4.3 \\
0.0\end{array}$ & $\begin{array}{r}0.3 \\
-2.5 \\
6.9 \\
2.8 \\
-3.8 \\
8.7 \\
8.7 \\
-2.2 \\
6.6\end{array}$ & $\begin{array}{r}2.7 \\
2.6 \\
5.6 \\
-4.8 \\
1.7 \\
8.0 \\
-4.6 \\
3.8\end{array}$ & $\begin{array}{r}2.0 \\
3.0 \\
4.2 \\
8.8 \\
1.2 \\
-8.4 \\
-3.3 \\
5.9\end{array}$ & $\begin{array}{r}\mathbf{0 . 1} \\
2.8 \\
3.5 \\
0.2 \\
3.3 \\
-11.5 \\
-0.5 \\
-7.8\end{array}$ & $\begin{array}{r}4.0 \\
2.6 \\
3.7 \\
1.4 \\
4.4 \\
-5.1 \\
2.2 \\
6.8\end{array}$ & $\begin{array}{r}4.5 \\
4.1 \\
2.2 \\
4.2 \\
3.6 \\
1.9 \\
1.8 \\
10.2\end{array}$ & $\begin{array}{r}3.4 \\
3.5 \\
3.0 \\
3.5 \\
2.5 \\
-2.5 \\
0.0 \\
7.5\end{array}$ & $\begin{array}{r}24.1 \\
6.4 \\
51.1 \\
29.0 \\
25.1 \\
-11.4 \\
-18.2 \\
23.2\end{array}$ \\
\hline $\begin{array}{l}\text { Non-oil-exporting } \\
\text { countries }\end{array}$ & 3.3 & 6.3 & 3.7 & 0.0 & 1.4 & -2.4 & 2.8 & 1.6 & 15.0 \\
\hline $\begin{array}{l}\text { South America } \\
\text { Argentina } \\
\text { Brazil } \\
\text { Chile } \\
\text { Guyana } \\
\text { Paraguay } \\
\text { Suriname } \\
\text { Uruguay }\end{array}$ & $\begin{array}{r}3.6 \\
-5.1 \\
7.9 \\
2.2 \\
1.1 \\
4.0 \\
2.0 \\
1.7\end{array}$ & $\begin{array}{r}6.7 \\
5.2 \\
7.6 \\
5.7 \\
0.3 \\
-0.3 \\
0.8 \\
8.3\end{array}$ & $\begin{array}{r}3.7 \\
3.1 \\
3.6 \\
5.7 \\
0.8 \\
4.5 \\
-6.2 \\
7.9\end{array}$ & $\begin{array}{r}0.0 \\
-1.8 \\
-0.1 \\
7.5 \\
-2.6 \\
6.7 \\
8.2 \\
-0.2\end{array}$ & $\begin{array}{r}1.2 \\
-6.3 \\
3.3 \\
9.8 \\
-4.9 \\
5.9 \\
4.2 \\
1.5\end{array}$ & $\begin{array}{r}-2.6 \\
0.2 \\
-4.4 \\
2.0 \\
-3.0 \\
3.1 \\
-1.7 \\
0.7\end{array}$ & $\begin{array}{r}2.9 \\
7.3 \\
0.9 \\
5.8 \\
6.0 \\
2.3 \\
-2.5 \\
1.6\end{array}$ & $\begin{array}{r}1.5 \\
6.0 \\
-1.5 \\
9.5 \\
3.0 \\
1.5 \\
0.0 \\
7.0\end{array}$ & $\begin{array}{r}14.4 \\
4.1 \\
15.2 \\
53.0 \\
-18.4 \\
41.8 \\
0.8 \\
10.2\end{array}$ \\
\hline $\begin{array}{l}\text { Central Ameriça and } \\
\text { the Caribbean } \\
\text { Bahamas } \\
\text { Barbados } \\
\text { Belize } \\
\text { Cuba } \\
\text { Haiti } \\
\text { Jamaica } \\
\text { Panama } \\
\text { Dominican Republic }\end{array}$ & $\begin{array}{r}0.5 \\
13.5 \\
0.9 \\
0.3 \\
4.6 \\
0.4 \\
-5.4 \\
4.8 \\
-1.9\end{array}$ & $\begin{array}{l}2.2 \\
3.6 \\
5.2 \\
4.5 \\
1.2 \\
0.0 \\
2.2 \\
3.4 \\
3.0\end{array}$ & $\begin{array}{r}4.4 \\
4.9 \\
2.6 \\
12.9 \\
-3.9 \\
-0.7 \\
6.7 \\
2.2 \\
8.4\end{array}$ & $\begin{array}{r}0.0 \\
2.3 \\
3.5 \\
10.0 \\
2.2 \\
0.9 \\
1.1 \\
-15.9 \\
1.5\end{array}$ & $\begin{array}{r}3.3 \\
2.0 \\
3.6 \\
14.2 \\
1.1 \\
1.0 \\
6.3 \\
-0.2 \\
4.1\end{array}$ & $\begin{array}{r}0.9 \\
1.0 \\
-3.3 \\
7.6 \\
\ldots .0 \\
-0.2 \\
3.8 \\
5.2 \\
-5.5\end{array}$ & $\begin{array}{r}1.4 \\
-2.0 \\
-3.3 \\
4.8 \\
\ldots . . \\
-0.3 \\
1.9 \\
9.1 \\
-1.0\end{array}$ & $\begin{array}{r}2.5 \\
1.0 \\
-2.5 \\
\cdots \\
\ldots . \\
-5.0 \\
1.5 \\
7.5 \\
7.5\end{array}$ & $\begin{array}{r}20.9 \\
46.9 \\
2.8 \\
\ldots \\
\ldots . \\
-8.9 \\
23.4 \\
24.7 \\
29.3\end{array}$ \\
\hline $\begin{array}{l}\text { Central American } \\
\text { Common Market } \\
\text { Costa Rica } \\
\text { El Salvador } \\
\text { Guatemala } \\
\text { Honduras } \\
\text { Nicaragua }\end{array}$ & $\begin{array}{r}\mathbf{0 . 1} \\
0.7 \\
1.8 \\
-0.6 \\
2.8 \\
-4.1\end{array}$ & $\begin{array}{r}1.4 \\
5.3 \\
0.5 \\
0.3 \\
2.3 \\
-1.0\end{array}$ & $\begin{array}{r}\mathbf{3 . 3} \\
4.5 \\
2.7 \\
3.6 \\
4.9 \\
-0.7\end{array}$ & $\begin{array}{r}1.8 \\
3.2 \\
1.5 \\
4.0 \\
4.9 \\
-12.1\end{array}$ & $\begin{array}{r}3.3 \\
5.4 \\
1.1 \\
3.7 \\
4.7 \\
-1.9\end{array}$ & $\begin{array}{r}2.3 \\
3.5 \\
3.4 \\
2.9 \\
-0.5 \\
-0.7\end{array}$ & $\begin{array}{r}2.3 \\
1.2 \\
3.3 \\
3.2 \\
2.2 \\
-0.5\end{array}$ & $\begin{array}{l}3.9 \\
4.0 \\
4.5 \\
4.0 \\
4.5 \\
0.5\end{array}$ & $\begin{array}{r}16.8 \\
31.7 \\
6.9 \\
17.0 \\
33.8 \\
-13.4\end{array}$ \\
\hline $\begin{array}{l}\text { OECS countries } \\
\text { Antigua and Barbuda } \\
\text { Dominica } \\
\text { Grenada } \\
\text { Saint Kitts and Nevis } \\
\text { Saint Lucia } \\
\text { Saint Vincent and } \\
\text { the Grenadines }\end{array}$ & $\begin{array}{l}7.1 \\
8.7 \\
1.6 \\
5.0 \\
5.7 \\
9.1\end{array}$ & $\begin{array}{l}6.5 \\
9.7 \\
6.8 \\
5.4 \\
6.1 \\
5.0\end{array}$ & $\begin{array}{l}\mathbf{5 . 0} \\
9.1 \\
6.8 \\
6.0 \\
7.4 \\
0.5\end{array}$ & $\begin{array}{l}8.1 \\
7.7 \\
8.0 \\
5.3 \\
9.8 \\
9.2\end{array}$ & $\begin{array}{r}5.0 \\
5.2 \\
-1.2 \\
5.7 \\
6.7 \\
5.4\end{array}$ & $\begin{array}{l}4.9 \\
2.7 \\
6.6 \\
5.3 \\
3.1 \\
5.6\end{array}$ & $\begin{array}{r}3.1 \\
\ldots \\
2.1 \\
3.1 \\
6.8 \\
1.8\end{array}$ & $\begin{array}{r}4.2 \\
\ldots \\
2.0 \\
0.5 \\
\cdots \\
\cdots\end{array}$ & $\begin{array}{r}78.0 \\
61.4 \\
63.5 \\
\ldots \\
\cdots\end{array}$ \\
\hline
\end{tabular}


Table 3

\section{LATIN AMERICA AND THE CARIBBEAN: GROWTH OF \\ PER CAPITA GROSS DOMESTIC PRODUCT}

(Percentages based on values at 1980 prices)

\begin{tabular}{|c|c|c|c|c|c|c|c|c|c|}
\hline \multirow[b]{3}{*}{$\begin{array}{l}\text { Latin America and } \\
\text { the Caribbean }\end{array}$} & \multicolumn{8}{|c|}{ Average annual rates } & \multirow{2}{*}{$\begin{array}{c}\begin{array}{c}\text { Cumulative } \\
\text { variation }\end{array} \\
\frac{1981-1992^{\mathrm{a}}}{}\end{array}$} \\
\hline & 1985 & 1986 & 1987 & 1988 & 1989 & 1990 & 1991 & $1992^{\mathrm{a}}$ & \\
\hline & 0.6 & 1.6 & 1.2 & -1.2 & -1.1 & -1.6 & 1.6 & 0.5 & -7.3 \\
\hline $\begin{array}{l}\text { Oil-exporting } \\
\text { countries } \\
\text { Bolivia } \\
\text { Colombia } \\
\text { Ecuador } \\
\text { Mexico } \\
\text { Peru } \\
\text { Trinidad and Tobago } \\
\text { Venezuela }\end{array}$ & $\begin{array}{r}-0.2 \\
-3.4 \\
1.7 \\
1.2 \\
0.2 \\
0.0 \\
-5.6 \\
-2.5\end{array}$ & $\begin{array}{r}-2.0 \\
-4.9 \\
4.9 \\
0.2 \\
-5.9 \\
6.4 \\
-3.5 \\
4.0\end{array}$ & $\begin{array}{r}0.4 \\
0.1 \\
3.7 \\
-7.2 \\
-0.5 \\
5.8 \\
-5.9 \\
1.3\end{array}$ & $\begin{array}{r}-0.2 \\
0.5 \\
2.3 \\
6.1 \\
-1.0 \\
-10.3 \\
-4.5 \\
3.4\end{array}$ & $\begin{array}{r}-2.0 \\
0.4 \\
1.7 \\
-2.3 \\
1.0 \\
-13.3 \\
-1.8 \\
-9.9\end{array}$ & $\begin{array}{r}1.9 \\
0.2 \\
1.9 \\
-1.0 \\
2.2 \\
-7.0 \\
1.0 \\
4.4\end{array}$ & $\begin{array}{r}2.4 \\
1.7 \\
0.5 \\
1.7 \\
1.4 \\
-0.1 \\
0.6 \\
7.8\end{array}$ & $\begin{array}{r}1.3 \\
1.1 \\
1.4 \\
1.1 \\
0.6 \\
-4.5 \\
-1.2 \\
5.0\end{array}$ & $\begin{array}{r}-5.2 \\
-21.1 \\
19.9 \\
-5.2 \\
-4.8 \\
-31.8 \\
-30.0 \\
-8.3\end{array}$ \\
\hline $\begin{array}{l}\text { Non-oil-exporting } \\
\text { countries }\end{array}$ & 1.3 & 4.3 & 1.7 & -1.8 & -0.4 & -4.1 & 1.0 & 0.0 & -9.0 \\
\hline $\begin{array}{l}\text { South America } \\
\text { Argentina } \\
\text { Brazil } \\
\text { Chile } \\
\text { Guyana } \\
\text { Faraguay } \\
\text { Suriname } \\
\text { Uruguay }\end{array}$ & $\begin{array}{r}1.6 \\
-6.4 \\
5.7 \\
0.5 \\
0.5 \\
0.9 \\
0.0 \\
1.0\end{array}$ & $\begin{array}{r}4.7 \\
3.8 \\
5.5 \\
4.0 \\
0.0 \\
-3.3 \\
-1.1 \\
7.7\end{array}$ & $\begin{array}{r}1.8 \\
1.8 \\
1.6 \\
3.9 \\
-0.8 \\
1.4 \\
-8.0 \\
7.3\end{array}$ & $\begin{array}{r}-1.7 \\
-3.0 \\
-2.0 \\
5.7 \\
-2.6 \\
3.6 \\
6.1 \\
-0.7\end{array}$ & $\begin{array}{r}-0.5 \\
-7.5 \\
1.4 \\
8.0 \\
-5.0 \\
2.9 \\
2.2 \\
0.9\end{array}$ & $\begin{array}{r}-4.3 \\
-1.0 \\
-6.1 \\
0.3 \\
-3.4 \\
0.2 \\
-3.5 \\
0.2\end{array}$ & $\begin{array}{r}1.3 \\
6.0 \\
-0.8 \\
4.1 \\
5.3 \\
-0.5 \\
-4.3 \\
1.0\end{array}$ & \begin{tabular}{r|}
-0.1 \\
4.8 \\
-3.1 \\
7.8 \\
2.1 \\
-1.3 \\
-1.9 \\
6.4
\end{tabular} & $\begin{array}{r}-8.4 \\
-11.2 \\
-9.3 \\
25.4 \\
-23.4 \\
-1.3 \\
-19.0 \\
2.6\end{array}$ \\
\hline $\begin{array}{l}\text { Central America and } \\
\text { the Caribbean } \\
\text { Bahamas } \\
\text { Barbados } \\
\text { Belize } \\
\text { Cuba } \\
\text { Haiti } \\
\text { Jamaica } \\
\text { Panama } \\
\text { Dominican Republic }\end{array}$ & $\begin{array}{r}-1.8 \\
11.3 \\
0.6 \\
-2.3 \\
3.6 \\
-1.5 \\
-6.7 \\
2.6 \\
-4.1\end{array}$ & $\begin{array}{r}-0.1 \\
1.7 \\
4.8 \\
1.7 \\
0.2 \\
-1.9 \\
1.1 \\
1.2 \\
0.7\end{array}$ & $\begin{array}{r}2.0 \\
3.0 \\
2.3 \\
9.9 \\
-4.8 \\
-2.6 \\
5.7 \\
0.1 \\
6.0\end{array}$ & $\begin{array}{r}-2.3 \\
0.5 \\
3.2 \\
7.1 \\
1.1 \\
-1.1 \\
0.3 \\
-17.6 \\
-0.7\end{array}$ & $\begin{array}{r}0.9 \\
0.2 \\
3.3 \\
11.3 \\
0.0 \\
-1.0 \\
5.4 \\
-2.2 \\
1.8\end{array}$ & $\begin{array}{r}-1.5 \\
-0.7 \\
-3.6 \\
5.0 \\
-2 . \\
-2.2 \\
2.9 \\
3.1 \\
-7.5\end{array}$ & $\begin{array}{r}-1.4 \\
-3.7 \\
-3.6 \\
2.5 \\
\ldots . . \\
-2.3 \\
0.9 \\
7.0 \\
-3.1\end{array}$ & $\begin{array}{r}1.7 \\
-0.7 \\
-3.0 \\
\cdots \\
\ldots . . \\
-6.9 \\
0.5 \\
5.4 \\
5.5\end{array}$ & $\begin{array}{r}-8.7 \\
16.8 \\
-1.0 \\
\ldots \\
\ldots . . \\
-27.8 \\
6.6 \\
-3.0 \\
-1.4\end{array}$ \\
\hline $\begin{array}{l}\text { Central American } \\
\text { Common Market } \\
\text { Costa Rica } \\
\text { El Salvador } \\
\text { Guatemala } \\
\text { Honduras } \\
\text { Nicaragua }\end{array}$ & $\begin{array}{r}-2.4 \\
-2.1 \\
0.6 \\
-3.4 \\
-0.7 \\
-6.7\end{array}$ & $\begin{array}{r}-1.2 \\
2.3 \\
-1.0 \\
-2.6 \\
-1.1 \\
-3.5\end{array}$ & $\begin{array}{r}0.7 \\
1.6 \\
1.0 \\
0.7 \\
1.6 \\
-3.0\end{array}$ & $\begin{array}{r}-0.8 \\
0.4 \\
-0.3 \\
1.0 \\
1.6 \\
-14.2\end{array}$ & $\begin{array}{r}0.5 \\
2.6 \\
-0.8 \\
0.8 \\
1.5 \\
-4.5\end{array}$ & $\begin{array}{r}-0.5 \\
0.8 \\
1.4 \\
0.0 \\
-3.5 \\
-3.7\end{array}$ & $\begin{array}{r}-0.5 \\
-1.4 \\
1.2 \\
0.3 \\
-0.9 \\
-4.0\end{array}$ & $\begin{array}{r}1.0 \\
1.5 \\
2.4 \\
1.2 \\
1.2 \\
-3.4\end{array}$ & $\begin{array}{r}-15.0 \\
-5.7 \\
-10.4 \\
-16.9 \\
-10.3 \\
-38.6\end{array}$ \\
\hline $\begin{array}{l}\text { OECS countries } \\
\text { Antigua and Barbuda } \\
\text { Dominica } \\
\text { Grenada } \\
\text { Saint Kitts and Nevis } \\
\text { Saint Lucia } \\
\text { Saint Vincent and } \\
\text { the Grenadines }\end{array}$ & $\begin{array}{l}6.5 \\
7.9 \\
2.2 \\
4.7 \\
6.2 \\
7.5 \\
\\
6.3\end{array}$ & $\begin{array}{l}\mathbf{5 . 9} \\
9.1 \\
7.2 \\
5.2 \\
6.6 \\
3.5\end{array}$ & $\begin{array}{r}4.0 \\
8.4 \\
7.1 \\
5.8 \\
7.9 \\
-0.9\end{array}$ & $\begin{array}{r}7.4 \\
7.1 \\
8.2 \\
5.0 \\
10.3 \\
7.7\end{array}$ & $\begin{array}{r}4.4 \\
4.5 \\
-0.9 \\
5.4 \\
7.2 \\
3.9\end{array}$ & $\begin{array}{l}4.3 \\
2.0 \\
6.9 \\
5.0 \\
3.6 \\
4.1\end{array}$ & $\begin{array}{r}2.5 \\
\ldots . . \\
2.4 \\
2.8 \\
7.3 \\
0.5\end{array}$ & $\begin{array}{r}3.9 \\
\ldots .4 \\
2.4 \\
0.4 \\
\ldots \\
\ldots\end{array}$ & $\begin{array}{r}71.5 \\
\ldots \\
69.1 \\
59.3 \\
\ldots \\
\ldots\end{array}$ \\
\hline
\end{tabular}


Table 4

LATIN AMERICA AND THE CARIBBEAN: URBAN UNEMPLOYMENT

(Average annual rates)

\begin{tabular}{|c|c|c|c|c|c|c|c|c|c|}
\hline & 1984 & 1985 & 1986 & 1987 & 1988 & 1989 & 1990 & 1991 & $1992^{\mathrm{a}}$ \\
\hline Argentina $^{b}$ & 4.6 & 6.1 & 5.6 & 5.9 & 6.3 & 7.6 & 7.5 & 6.5 & 6.9 \\
\hline Bolivia $^{c}$ & 6.9 & 5.8 & 7.0 & 7.2 & 11.6 & 10.2 & 9.5 & 7.0 & 6.8 \\
\hline Brazil $^{d}$ & 7.1 & 5.3 & 3.6 & 3.7 & 3.8 & 3.3 & 4.3 & 4.8 & 5.9 \\
\hline Colombia $^{e}$ & 13.4 & 14.1 & 13.8 & 11.8 & 11.2 & 9.9 & 10.3 & 10.0 & 10.5 \\
\hline Costa Rica ${ }^{b} \mathbf{f}$ & 6.6 & 6.7 & 6.7 & 5.9 & 6.3 & 3.7 & 5.4 & 6.0 & 4.3 \\
\hline Chile $^{\mathrm{g}}$ & 18.5 & 17.0 & 13.1 & 11.9 & 10.2 & 7.2 & 6.5 & 7.3 & 5.0 \\
\hline Ecuador $^{h}$ & 10.5 & 10.4 & 10.7 & 7.2 & 7.4 & 7.9 & 6.1 & 8.5 & $\ldots$ \\
\hline El Salvador ${ }^{b}$ & $\cdots$ & $\ldots$ & $\ldots$ & $\cdots$ & 9.4 & 8.4 & 10.0 & 8.0 & $\cdots$ \\
\hline Guatemala $^{\mathrm{i}}$ & 9.1 & 12.0 & 14.0 & 11.4 & 8.8 & 6.2 & 6.4 & 6.5 & $\cdots$ \\
\hline Honduras $^{j}$ & 10.7 & 11.7 & 12.1 & 11.4 & 8.7 & 7.2 & 6.9 & 7.6 & $\ldots$ \\
\hline Mexico $^{\text {k }}$ & 5.7 & 4.4 & 4.3 & 3.9 & 3.5 & 2.9 & 2.9 & 2.7 & 3.2 \\
\hline Panama $^{1}$ & 12.4 & 15.7 & 12.7 & 14.1 & 21.1 & 20.4 & 20.0 & 19.8 & 18.0 \\
\hline Paraguay $^{m}$ & 7.3 & 5.1 & 6.1 & 5.5 & 4.7 & 6.1 & 6.6 & 5.1 & 6.0 \\
\hline Peru ${ }^{n}$ & 8.9 & 10.1 & 5.4 & 4.8 & 7.9 & 7.9 & 8.3 & 5.9 & $\ldots$ \\
\hline Uruguay $^{\circ}$ & 14.0 & 13.1 & 10.7 & 9.3 & 9.1 & 8.6 & 9.3 & 8.9 & 9.3 \\
\hline Venezuela $^{b}$ & 14.3 & 14.3 & 12.1 & 9.9 & 7.9 & 9.7 & 10.5 & 10.1 & 8.0 \\
\hline
\end{tabular}

Source: ECLAC and PREALC, on the basis of official figures.
${ }^{a}$ Preliminary figures. ${ }^{\text {b National urban. }}{ }^{c}$ National. a Preliminary figures. ${ }^{b}$ National urban. $\quad$ "National. "Metropolitan areas of Rio de Janeiro, São Paulo, Belo Horizonte,
Porto Alegre, Salvador and Recife. strictly comparable with the data for preceding years owing to the change in methodology for the multi-purpose household surveys. ${ }^{B}$ Greater Santiago. As from August 1983 data relate to metropolitan area of Santiago. As from October 1985, the figures are not strictly comparable with those for preceding periods, owing to changes in the make-up and size of the samples. ${ }^{h}$ Country total. From 1986 on, Permanent Household Survey in Quito, Guayaquil and Cuenca. i Country total. 'j Country total up to 1985; 1986: urban labour force survey; 1987: Central District and San Pedro de Sula and five cities; 1988: national urban; from 1989 on: Tegucigalpa. ${ }^{k}$ Metropolitan areas of Mexico City, Guadalajara and Monterrey. ${ }^{1}$ Metropolitan Region; 1992, estimate. ${ }^{\mathrm{m}}$ Asunción, Fernando de la Mora, Lambaré and the urban areas of Luque and San Lorenzo, 1992,
estimate. " ${ }^{\circ}$ Metropolitan Lima. 
Table 5

\section{LATIN AMERICA AND THE CARIBBEAN: VARIATIONS}

IN CONSUMER PRICE INDEXES

(December-December variations)

\begin{tabular}{|c|c|c|c|c|c|c|c|c|c|}
\hline & 1984 & 1985 & 1986 & 1987 & 1988 & 1989 & 1990 & 1991 & 1992 \\
\hline $\begin{array}{l}\text { Latin America and } \\
\text { the Caribbean }\end{array}$ & 188.3 & 280.1 & 64.1 & 208.9 & 773.5 & 1205.0 & 1185.0 & 198.7 & 410.7 \\
\hline Argentina & 688.0 & 385.4 & 81.9 & 174.8 & 387.7 & 4923.6 & 1343.9 & 84.0 & $18.0^{\mathrm{b}}$ \\
\hline Barbados & 5.1 & 2.4 & -0.5 & 6.3 & 4.4 & 6.6 & 3.4 & 8.1 & $5.8^{\mathrm{c}}$ \\
\hline Bolivia & 2177.2 & 8170.5 & 66.0 & 10.7 & 21.5 & 16.6 & 18.0 & 14.5 & $11.4^{\mathrm{d}}$ \\
\hline Brazil & 209.1 & 239.0 & 59.2 & 394.7 & 992.7 & 1861.6 & 1584.6 & 475.8 & $1131.5^{b}$ \\
\hline Colombia & 18.4 & 22.4 & 21.0 & 24.0 & 28.2 & 26.1 & 32.4 & 26.8 & $25.7^{b}$ \\
\hline Costa Rica & 17.3 & 10.9 & 15.4 & 16.4 & 25.3 & 10.0 & 27.3 & 25.3 & $18.1^{d}$ \\
\hline Chile & 23.2 & 26.2 & 17.4 & 21.4 & 12.7 & 21.5 & 27.3 & 18.7 & $14.0^{b}$ \\
\hline Ecuador & 25.1 & 24.4 & 27.3 & 32.5 & 85.7 & 54.2 & 49.5 & 49.0 & $66.0^{d}$ \\
\hline El Salvador & 9.1 & 31.9 & 30.3 & 19.6 & 18.2 & 23.5 & 19.3 & 9.8 & $16.8^{d}$ \\
\hline Guatemala & 7.2 & 27.9 & 21.4 & 9.3 & 12.3 & 20.2 & 59.6 & 10.2 & $11.6^{\mathrm{d}}$ \\
\hline Haiti & 5.4 & 17.4 & -11.4 & -4.1 & 8.6 & 10.9 & 26.1 & 6.6 & $17.5^{b}$ \\
\hline Honduras & 2.7 & 4.2 & 3.2 & 2.9 & 6.6 & 11.5 & 36.4 & 21.4 & $5.4^{d}$ \\
\hline Jamaica & 31.2 & 23.3 & 10.4 & 8.4 & 8.9 & 17.2 & 29.7 & 76.8 & $13.7^{\circ}$ \\
\hline Mexico & 59.2 & 63.7 & 105.7 & 159.2 & 51.7 & 19.7 & 29.9 & 18.8 & $12.9^{b}$ \\
\hline Nicaragua & 47.3 & 334.3 & 747.4 & 1347.2 & 33547.6 & 1689.1 & 13490.2 & 775.4 & $2.2^{d}$ \\
\hline Panama & 0.9 & 0.4 & 0.4 & 0.9 & 0.3 & -0.2 & 1.2 & 1.1 & $1.2^{\mathrm{e}}$ \\
\hline Paraguay & 29.8 & 23.1 & 24.1 & 32.0 & 16.9 & 28.5 & 44.1 & 11.8 & $17.0^{b}$ \\
\hline Peru & 111.5 & 158.3 & 62.9 & 114.5 & 1722.6 & 2775.3 & 7649.6 & 139.2 & $56.6^{b}$ \\
\hline Dominican Republic & 40.9 & 28.3 & 6.5 & 25.0 & 57.6 & 41.2 & 100.7 & 4.0 & $5.9^{\circ}$ \\
\hline Trinidad and Tobago & 14.1 & 6.5 & 9.9 & 8.3 & 12.1 & 9.3 & 9.5 & 2.3 & $7.7^{e}$ \\
\hline Uruguay & 66.0 & 83.2 & 70.6 & 57.3 & 69.0 & 89.2 & 129.0 & 81.5 & $58.6^{\mathrm{b}}$ \\
\hline Venezuela & 18.3 & 7.3 & 12.7 & 40.3 & 35.5 & 81.0 & 36.5 & 31.0 & $33.4^{d}$ \\
\hline
\end{tabular}

Source: International Monetary Fund, International Financial Statistics, November 1992, and information provided by the countries.

${ }^{2}$ Figures correspond to the variation in prices during the 12 -month period ending in the month indicated for each country.

${ }^{b}$ Corresponds to the variation between November 1991 and November 1992 . ${ }^{c}$ Corresponds to the variation between June 1991 and June 1992. Corresponds to the variation between October 1991 and October 1992. Corresponds to the variation between September 1991 and September 1992. 
Table 6

LATIN AMERICA AND THE CARIBBEAN: REAL AVERAGE WAGES

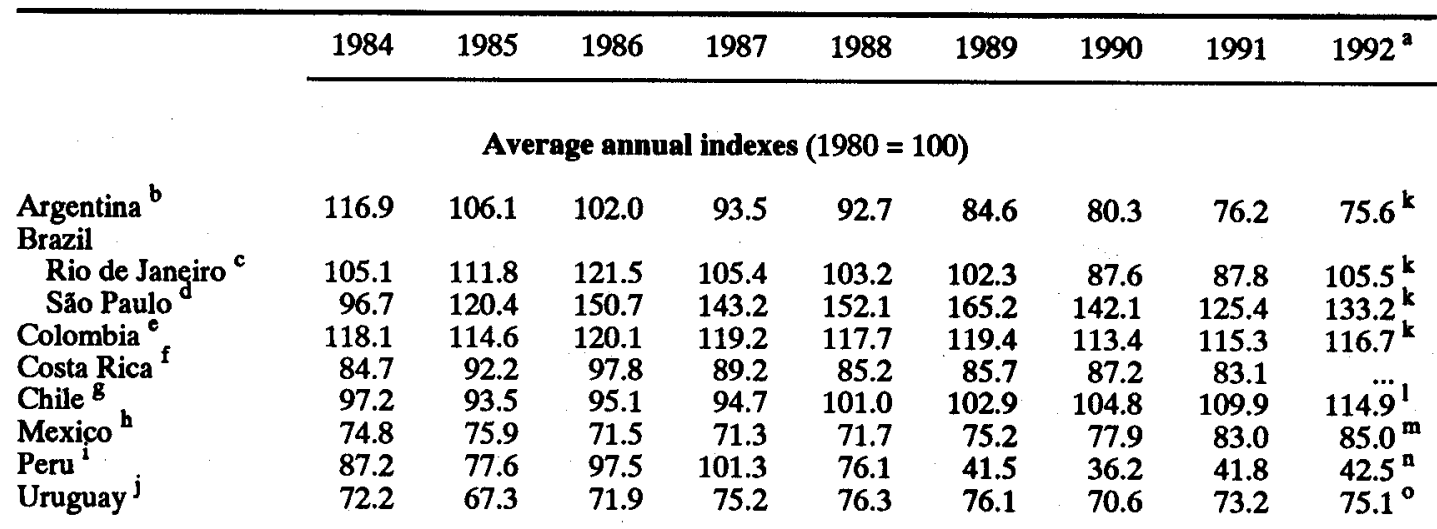

Percentage variation with respect to the same period of the preceding year

\begin{tabular}{lrrrrrrrrr} 
Argentina & 27.3 & -9.2 & -3.9 & -8.3 & -0.9 & -8.7 & -5.1 & -5.1 & -0.8 \\
Brazil & & & & & & & & & \\
$\quad$ Rio de Janeiro & -6.7 & 6.4 & 8.7 & -13.3 & -2.1 & -0.9 & -14.4 & 0.2 & 25.0 \\
$\quad$ São Paulo & 2.9 & 24.4 & 25.2 & -5.0 & 6.2 & 8.6 & -14.0 & -11.8 & 10.1 \\
Colombia & 7.3 & -3.0 & 4.8 & -0.7 & -1.3 & 1.4 & -5.0 & 1.7 & 0.3 \\
Costa Rica & 7.8 & 9.1 & 6.1 & -9.7 & -4.5 & 0.6 & 1.7 & -4.7 & $\ldots .7$ \\
Chile & 0.1 & -3.8 & 1.7 & -0.4 & 6.7 & 1.9 & 1.8 & 4.9 & 4.7 \\
Mexico & -7.3 & 1.5 & -5.8 & -0.3 & 0.6 & 4.9 & 3.6 & 6.5 & 8.2 \\
Peru & -6.6 & -11.0 & 25.6 & 3.9 & -24.9 & -45.5 & -12.8 & 15.5 & 1.9 \\
Uruguay & -14.8 & -6.8 & 6.8 & 4.6 & 1.5 & -0.3 & -7.2 & 3.7 & 3.3 \\
\hline
\end{tabular}

Source: ECLAC, on the basis of official figures.

${ }^{2}$ Preliminary figures. ${ }^{b}$ Average total wages in manufacturing. Twelve-month average. $\quad{ }^{c}$ Average wages in basic industry, deflated by the CPI for Rio de Janeiro. Twelve-month average. Wages in manufacturing in the State of Săo Paulo, deflated by the cost-of-living index for the city of São Paulo. Twelve-month average. 'Wages of manual workers in manufacturing.

${ }^{f}$ Average remunerations declared by persons covered by the social security system. B Average remunerations of wage-earners in non-agricultural sectors. Twelve-month average. $\quad$ Average wages in manufacturing. Twelve-month average. ${ }^{i}$ Wages of private-sector manual workers in the Lima metropolitan area. Index of average real wages. Twelve-month average.

Ianuary-August average. ${ }^{1}$ January-October average. 'manuary-June average." Average of February, April and June.

January-September average. 
Table 7

LATIN AMERICA AND THE CARIBBEAN: REAL URBAN MINIMUM WAGES

\begin{tabular}{|c|c|c|c|c|c|c|c|c|c|}
\hline & 1984 & 1985 & 1986 & 1987 & 1988 & 1989 & 1990 & 1991 & $1992^{2}$ \\
\hline \multicolumn{10}{|c|}{ Average annual indexes $(1980=100)$} \\
\hline 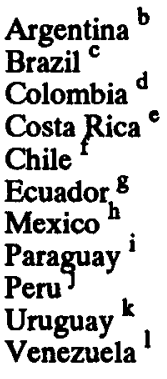 & $\begin{array}{r}167.5 \\
87.4 \\
113.5 \\
104.4 \\
80.7 \\
62.8 \\
72.3 \\
93.8 \\
62.3 \\
88.8 \\
66.5\end{array}$ & $\begin{array}{r}113.1 \\
88.9 \\
109.4 \\
112.2 \\
76.4 \\
60.4 \\
71.1 \\
99.6 \\
54.4 \\
93.2 \\
96.8\end{array}$ & $\begin{array}{r}110.0 \\
89.0 \\
114.2 \\
118.7 \\
73.6 \\
65.0 \\
64.9 \\
108.3 \\
56.4 \\
88.5 \\
90.4\end{array}$ & $\begin{array}{r}120.8 \\
72.6 \\
113.0 \\
117.9 \\
69.1 \\
61.4 \\
61.5 \\
122.6 \\
59.7 \\
90.3 \\
108.7\end{array}$ & $\begin{array}{r}93.5 \\
68.7 \\
109.9 \\
114.6 \\
73.9 \\
53.4 \\
54.2 \\
135.2 \\
52.0 \\
84.5 \\
89.5\end{array}$ & $\begin{aligned} 42.1 \\
72.1 \\
110.8 \\
119.4 \\
79.8 \\
46.5 \\
50.8 \\
137.5 \\
25.1 \\
78.0 \\
72.9\end{aligned}$ & $\begin{array}{r}40.2 \\
53.4 \\
107.9 \\
120.5 \\
87.5 \\
36.2 \\
45.5 \\
131.6 \\
23.4 \\
69.1 \\
59.3\end{array}$ & $\begin{array}{r}56.0 \\
59.9 \\
104.3 \\
111.8 \\
95.6 \\
30.4 \\
43.6 \\
125.8 \\
15.9 \\
62.0 \\
55.1\end{array}$ & $\begin{array}{r}100.0^{\circ} \\
31.7^{\mathrm{n}} \\
42.0^{\mathrm{m}} \\
115.0^{\mathrm{m}} \\
16.3^{\mathrm{m}} \\
61.5^{\mathrm{m}} \\
\ldots\end{array}$ \\
\hline
\end{tabular}

Percentage variation with respect to the same period of the preceding year

\begin{tabular}{lrrrrrrrrr} 
Argentina & 9.5 & -32.5 & -2.7 & 9.8 & -22.6 & -55.0 & -4.5 & 39.3 & -23.6 \\
Brazil & -8.9 & 1.7 & 0.1 & -18.4 & -5.4 & 4.9 & -25.9 & 12.2 & -10.0 \\
Colombia & 5.2 & -3.6 & 4.4 & -1.1 & -2.7 & 0.8 & -2.6 & -3.3 & -2.1 \\
Costa Rica & 5.1 & 7.5 & 5.8 & -0.7 & -2.8 & 4.2 & 0.9 & -7.2 & $\ldots$ \\
Chile & -14.3 & -5.3 & -3.7 & -6.1 & 6.9 & 8.0 & 9.6 & 9.3 & 4.9 \\
Ecuador & -1.3 & -3.8 & 7.6 & -5.6 & -13.0 & -12.9 & -22.2 & -16.0 & -0.4 \\
Mexico & -5.6 & -1.7 & -8.7 & -5.2 & -11.9 & -6.3 & -10.4 & -4.2 & -3.6 \\
Paraguay & -0.4 & 6.2 & 8.7 & 13.2 & 10.3 & 1.7 & -4.3 & -4.4 & -9.4 \\
Peru & -22.7 & -12.7 & 3.7 & 5.9 & -12.9 & -51.7 & -6.8 & -32.1 & -2.9 \\
Uruguay & 0.2 & 5.0 & -5.0 & 2.0 & -6.4 & -7.7 & -11.4 & -10.3 & -0.5 \\
Venezuela & -10.0 & 45.6 & -6.6 & 20.2 & -17.7 & -18.5 & -18.7 & -7.1 & $\ldots$ \\
\hline
\end{tabular}

Source: ECLAC, on the basis of official figures.

${ }^{2}$ Preliminary figures. $\quad{ }^{b}$ Nationwide minimum wage; 1990: not applicable. $\quad$ 'Minimum wage in the city of Rio de Janeiro, deflated by the corresponding CP1. dMinimum wage in upper urban sectors. 'Nationwide minimum wage.

${ }^{f}$ Minimum income. ${ }^{8}$ General minimum official living wage. ${ }^{b}$ Minimum wage in Mexico City, deflated by the corresponding CPI. ${ }^{i}$ Minimum wage in Asunción. ${ }^{j}$ Minimum wage in the Lima metropolitan area for non-agricultural

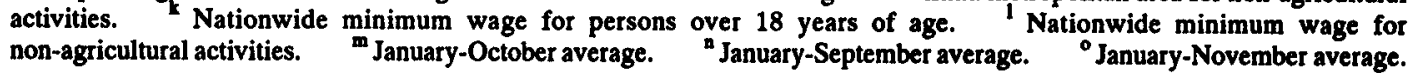


Table 8

LATIN AMERICA AND THE CARIBBEAN: PUBLIC SECTOR DEFICIT (-) OR SURPLUS ${ }^{2}$

(Percentages of gross domestic product)

\begin{tabular}{|c|c|c|c|c|c|c|c|}
\hline & Coverage & 1987 & 1988 & 1989 & 1990 & $1991^{b}$ & $1992^{b}$ \\
\hline Argentina & NNFPS & -6.7 & -8.6 & -4.8 & -5.1 & -2.2 & - \\
\hline Bolivia & NFPS & $\cdots$ & $\cdots$ & -4.5 & -3.9 & -3.0 & -3.0 \\
\hline Brazil & NFPS $^{c}$ & -5.7 & -4.8 & -6.9 & 1.2 & 0.3 & -1.5 \\
\hline Colombia & NFPS & $\ldots$ & -2.1 & -1.9 & -0.4 & 0.1 & -0.4 \\
\hline Costa Rica & CG & -2.0 & -2.5 & -4.1 & -4.4 & -3.1 & -2.0 \\
\hline Chile & NFPS & 2.6 & 3.9 & 5.5 & 1.5 & 1.7 & 1.8 \\
\hline Ecuador & NFPS & -9.6 & -5.3 & -1.6 & 0.6 & -1.2 & -3.2 \\
\hline El Salvador & $\mathrm{CG}$ & -3.8 & -3.2 & -4.5 & -3.2 & -4.6 & -4.7 \\
\hline Guatemala & CG & -2.5 & -2.5 & -3.8 & -2.3 & 0.4 & -0.5 \\
\hline Haiti & $\mathrm{CG}$ & -7.0 & -5.2 & -6.6 & -5.8 & -3.9 & $\ldots$ \\
\hline Honduras & CG & -6.6 & -6.9 & -7.3 & -6.3 & -3.1 & -5.8 \\
\hline \multirow[t]{2}{*}{ Mexico } & CPS & -15.5 & -12.5 & -5.7 & -4.0 & 1.8 & 3.4 \\
\hline & CG & -14.3 & -9.7 & -5.1 & -2.9 & 3.4 & 4.6 \\
\hline Nicaragua & CG & -16.6 & -26.6 & -6.7 & -19.7 & -8.0 & -7.3 \\
\hline Panama & CG & -4.6 & -5.4 & -7.3 & -2.4 & -3.3 & -3.0 \\
\hline Paraguay & CG & -0.1 & 0.7 & 1.5 & 2.9 & -0.4 & -0.5 \\
\hline Peru & $\mathbf{C G}$ & -5.7 & -2.5 & -4.2 & -2.5 & -0.6 & -1.0 \\
\hline $\begin{array}{l}\text { Dominican } \\
\text { Republic }\end{array}$ & $C G$ & -2.2 & -1.6 & -0.1 & 0.3 & 0.8 & 3.0 \\
\hline Uruguay & CG & -1.3 & -2.0 & -3.4 & -0.1 & 0.4 & 1.0 \\
\hline Venezuela & NFPS & -4.4 & -8.6 & -1.1 & 0.2 & 1.2 & -7.5 \\
\hline
\end{tabular}


Table 9

\section{LATIN AMERICA AND THE CARIBBEAN: REAL EFFECTIVE EXCHANGE RATE INDEXES FOR EXPORTS ${ }^{\text {a }}$ \\ (Indexes 1985=100)}

\begin{tabular}{llllllllllllll}
\hline Country & $\begin{array}{c}\text { De- } \\
\text { flator. }\end{array}$ & 1978 & $\begin{array}{c}1979- \\
1981\end{array}$ & 1983 & 1984 & 1985 & 1986 & 1987 & 1988 & 1989 & 1990 & 1991 & $1992^{\mathrm{c}}$ \\
\hline
\end{tabular}

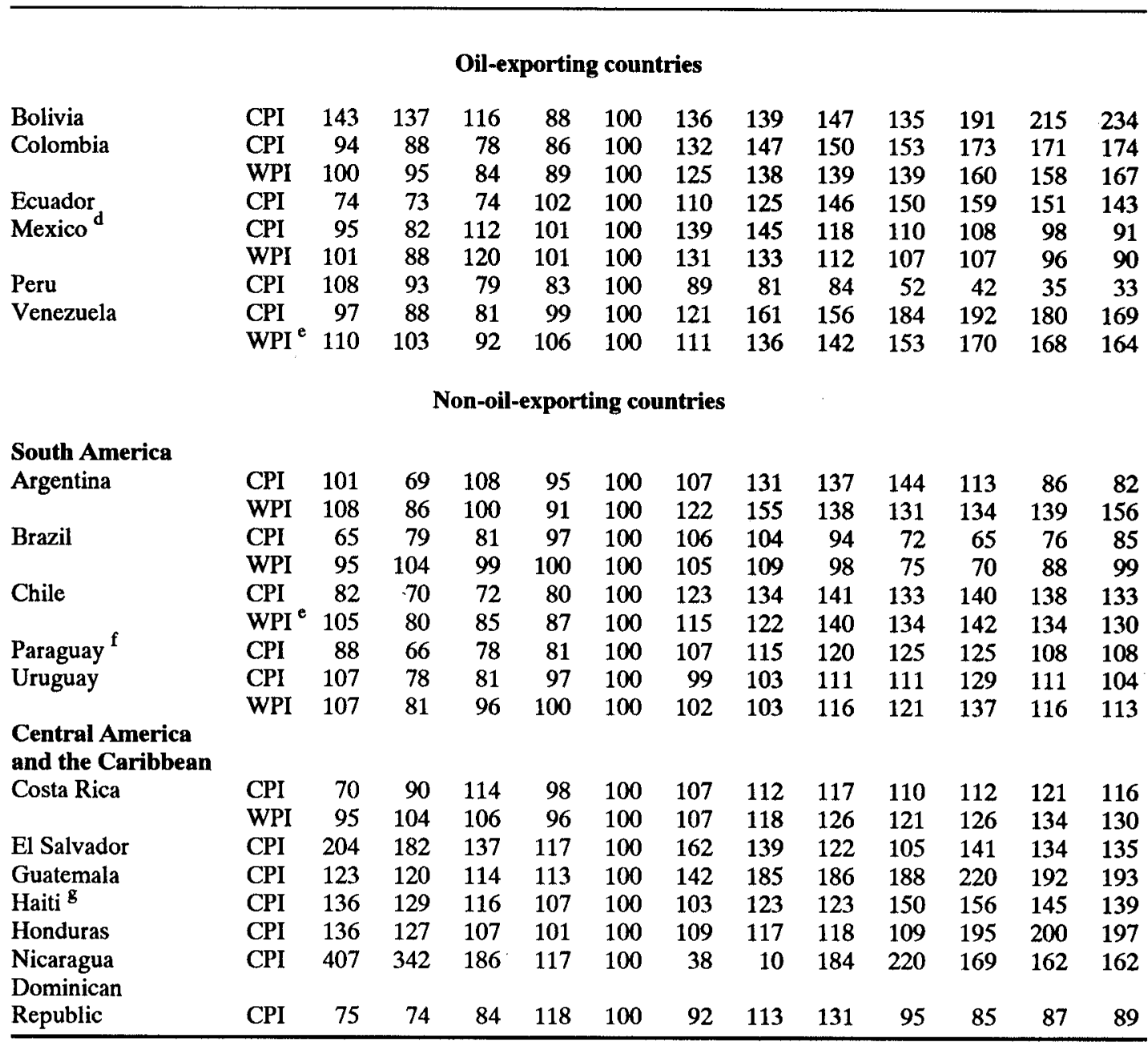

Source: ECLAC, on the basis of figures compiled by the International Monetary Fund.

${ }^{a}$ Corresponds to the average indexes of the real exchange rate (official principal) between the currency of each country and the currencies of its main trading partners weighted by the relative participation of each of those countries in the exports of the country under analysis. These weightings correspond to the average for the period 1986-1990. For the methodology and sources used, see ECLAC, Economic Survey of Latin America, 1981(E/CEPAL/G.1248), Santiago, Chile, 1983. United Nations publication, Sales No. E.83.II.G.2. $\quad{ }^{b}$ The abbreviation CPI indicates that the consumer price index was used in all the countries and the abbreviationWPI indicates that the wholesale price index was used in the country under analysis and in most of its trading partners. Where this information was not available, the consumer price index was used. ${ }^{c}$ January-to-September average. ${ }^{d}$ The exchange rate used was as follows: median rate between the average selling and buying rates declared by the main commercial banks to the Bank of Mexico up to July 1982; preferential rate for commodity imports from August to November 1982; and median rate between the selling and buying rates in the controlled market after November 1982. "National commodities subindex of the wholesale price index. Free or parallel exchange rate used. ${ }^{B}$ From 1987 on, the commercial exchange rate was used. 
Table 10

LATIN AMERICA AND THE CARIBBEAN: EXPORTS OF GOODS, FOB

(Indexes $1980=100$ and annual growth rates)

\begin{tabular}{|c|c|c|c|c|c|c|c|c|c|c|c|c|}
\hline & \multicolumn{4}{|c|}{ Value } & \multicolumn{4}{|c|}{ Unit value } & \multicolumn{4}{|c|}{ Volume } \\
\hline & \multirow{2}{*}{$\begin{array}{l}\text { Index } \\
1992^{a}\end{array}$} & \multicolumn{3}{|c|}{ Rates } & \multirow{2}{*}{$\begin{array}{l}\text { Index } \\
1992^{a}\end{array}$} & \multicolumn{3}{|c|}{ Rates } & \multirow{2}{*}{$\begin{array}{l}\text { Index } \\
1992^{a}\end{array}$} & \multicolumn{3}{|c|}{ Rates } \\
\hline & & 1990 & 1991 & $1992^{\mathrm{a}}$ & & 1990 & 1991 & $1992^{2}$ & & 1990 & 1991 & $1992^{\mathrm{a}}$ \\
\hline $\begin{array}{l}\text { Latin America and } \\
\text { the Caribbean }\end{array}$ & 142 & 9.6 & -0.4 & 4.0 & 76 & 3.8 & -4.4 & -2.3 & 186 & 5.7 & 4.0 & 6.4 \\
\hline $\begin{array}{l}\text { Oil-exporting } \\
\text { countries }\end{array}$ & 121 & 20.5 & -2.8 & -1.9 & 67 & 11.9 & -9.6 & -2.7 & 180 & 7.7 & 7.5 & \\
\hline Bolivia & 66 & 14.8 & -8.5 & -18.4 & 67 & -4.9 & -10.5 & -8.0 & 100 & 20.8 & 2.3 & $\begin{array}{r}0.0 \\
-11.3\end{array}$ \\
\hline Colombia & 179 & 17.4 & 6.9 & -5.8 & 82 & -1.0 & -3.4 & -3.5 & 218 & 18.6 & 10.7 & -2.3 \\
\hline Ecuador & 118 & 15.3 & 5.0 & 4.0 & 56 & 9.6 & -4.7 & -4.0 & 209 & 5.2 & 10.2 & 8.4 \\
\hline Mexico & 176 & 17.9 & 1.1 & 0.9 & 68 & 12.8 & -7.4 & -0.5 & 258 & 4.5 & 9.1 & 1.4 \\
\hline Peru & 85 & -7.4 & 3.0 & 0.2 & 92 & -2.6 & 0.0 & -2.0 & 93 & -4.9 & 3.0 & 2.2 \\
\hline Venezuela & 74 & 35.1 & -14.6 & -5.9 & 58 & 21.2 & -18.3 & -6.0 & 127 & 11.5 & 4.4 & 0.1 \\
\hline $\begin{array}{l}\text { Non-oil-exporting } \\
\text { countries }\end{array}$ & 165 & 1.4 & 1.7 & 9.1 & 87 & -2.1 & 1.3 & -2.0 & 191 & 3.6 & 0.5 & 11.3 \\
\hline South America & 178 & 0.5 & 0.4 & 10.2 & 85 & -2.4 & 0.7 & -1.6 & 210 & 2.9 & -0.3 & 12.0 \\
\hline Argentina & 158 & 29.1 & -3.1 & 6.1 & 78 & -4.0 & -2.0 & 1.0 & 204 & 34.5 & -1.1 & 5.0 \\
\hline Brazil & 177 & -8.6 & 0.7 & 12.6 & 86 & -1.3 & 2.1 & -2.0 & 205 & -7.4 & -1.4 & 14.9 \\
\hline Chile & 212 & 2.8 & 7.4 & 11.6 & 88 & -1.9 & 0.2 & -3.0 & 242 & 4.8 & 7.2 & 15.0 \\
\hline Paraguay & 275 & 10.8 & -7.8 & -13.2 & 94 & -2.9 & -1.1 & -8.0 & 294 & 14.1 & -6.8 & -5.6 \\
\hline Uruguay & 159 & 5.9 & -5.2 & 4.7 & 99 & -3.7 & -0.8 & -0.5 & 160 & 10.0 & -4.5 & 5.2 \\
\hline $\begin{array}{l}\text { Central America } \\
\text { and the Caribbean }\end{array}$ & 115 & 7.9 & 9.6 & 2.7 & 101 & -1.4 & 3.5 & -4.2 & 114 & 9.5 & 5.8 & 7.2 \\
\hline Costa Rica & 177 & 1.6 & 10.1 & 18.7 & 77 & -5.2 & 4.8 & -5.0 & 230 & 7.1 & $\begin{array}{l}5.8 \\
5.0\end{array}$ & $\begin{array}{r}1.2 \\
24.9\end{array}$ \\
\hline El Salvador & 54 & 16.6 & 1.3 & -0.5 & 70 & -28.0 & -1.8 & -7.0 & 78 & 61.9 & -0.4 & 7.1 \\
\hline Guatemala & 86 & 7.6 & 1.5 & 6.5 & 80 & -2.9 & -2.5 & -4.0 & 107 & 10.8 & 4.1 & 10.9 \\
\hline Haiti & 44 & 8.1 & 1.6 & -41.3 & 85 & -3.0 & 1.6 & -8.0 & 51 & 11.4 & 0.0 & -37.6 \\
\hline Honduras & 104 & -4.0 & -4.7 & 9.5 & 87 & -3.2 & -0.1 & -9.0 & 120 & -0.8 & -4.6 & 20.4 \\
\hline Nicaragua & 52 & 4.3 & -19.3 & -12.3 & 76 & -2.9 & -3.2 & -14.5 & 69 & 7.4 & -16.7 & 2.6 \\
\hline Panama & 183 & 23.8 & 25.2 & -0.3 & 156 & 12.4 & 1.0 & -1.5 & 117 & 10.1 & 23.9 & 1.1 \\
\hline Dominican Republic & 61 & -20.5 & -10.4 & -10.3 & 77 & -14.7 & -3.7 & -5.5 & 80 & -6.9 & -6.9 & -5.1 \\
\hline
\end{tabular}

Source: ECLAC.

a Preliminary estimates. 
Table 11

LATIN AMERICA AND THE CARIBBEAN: IMPORTS OF GOODS, FOB

(Indexes $1980=100$ and annual growth rates)

\begin{tabular}{|c|c|c|c|c|c|c|c|c|c|c|c|c|}
\hline & \multicolumn{4}{|c|}{ Value } & \multicolumn{4}{|c|}{ Unit value } & \multicolumn{4}{|c|}{ Volume } \\
\hline & \multirow{2}{*}{$\begin{array}{l}\text { Index } \\
1992^{\mathrm{a}}\end{array}$} & \multicolumn{3}{|c|}{ Rates } & \multirow{2}{*}{$\begin{array}{l}\text { Index } \\
1992^{a}\end{array}$} & \multicolumn{3}{|c|}{ Rates } & \multirow{2}{*}{$\begin{array}{l}\text { Index } \\
1992^{\mathrm{a}}\end{array}$} & \multicolumn{3}{|c|}{ Rates } \\
\hline & & 1990 & 1991 & $1992^{a}$ & & 1990 & 1991 & $1992^{\mathrm{a}}$ & & 1990 & 1991 & $1992^{\mathrm{a}}$ \\
\hline $\begin{array}{l}\text { Latin America and } \\
\text { the Caribbean }\end{array}$ & 146 & 15.7 & 18.1 & 18.4 & 107 & 4.2 & 1.3 & 1.0 & 205 & 11.1 & 16.6 & 17.2 \\
\hline $\begin{array}{l}\text { Oil-exporting } \\
\text { countries }\end{array}$ & 179 & 21.5 & 22.2 & 20.6 & 109 & 4.7 & 4.6 & 1.3 & 164 & 15.9 & 16.9 & 19.1 \\
\hline Bolivia & 154 & 6.3 & 3.7 & 10.1 & 114 & -2.5 & 10.8 & 2.0 & 135 & 9.0 & -6.5 & 8.0 \\
\hline Colombia & 130 & 12.1 & -11.2 & 22.8 & 112 & 5.8 & 2.1 & 2.0 & 116 & 5.9 & -13.0 & 20.3 \\
\hline Ecuador & 101 & 1.1 & 29.0 & 2.4 & 97 & 0.6 & 7.5 & 0.5 & 104 & 0.5 & 20.0 & 1.9 \\
\hline Mexico & 245 & 33.6 & 22.1 & 21.0 & 110 & 5.3 & 5.0 & 1.0 & 223 & 26.9 & 16.3 & 19.8 \\
\hline Peru & 129 & 26.2 & 20.9 & 13.6 & 127 & 12.3 & 10.4 & 1.0 & 101 & 12.4 & 9.5 & 12.5 \\
\hline Venezuela & 116 & -6.5 & 48.4 & 25.3 & 103 & 0.2 & 3.2 & 2.0 & 114 & -6.7 & 43.7 & 22.9 \\
\hline $\begin{array}{l}\text { Non-oil-exporting } \\
\text { countries }\end{array}$ & 120 & 10.2 & 13.9 & 15.8 & 104 & 3.8 & -2.2 & 0.7 & 115 & 6.0 & 16.5 & 15.0 \\
\hline South America & 114 & 11.1 & 14.1 & 17.0 & 100 & 3.9 & -3.6 & 0.4 & 114 & 6.9 & 18.3 & 16.5 \\
\hline Argentina & 139 & -3.6 & 98.6 & 76.6 & 114 & -4.1 & -0.9 & 0.5 & 122 & 0.5 & 100.4 & 75.6 \\
\hline Brazil & 88 & 13.1 & 1.7 & -4.3 & 96 & 4.8 & -6.7 & 0.0 & 92 & 8.0 & 9.0 & -4.3 \\
\hline Chile & 168 & 8.2 & 4.5 & 24.7 & 104 & 8.2 & -1.5 & 1.0 & 161 & 0.0 & 6.1 & 23.5 \\
\hline Paraguay & 233 & 45.0 & .14 .1 & -6.3 & 77 & -0.4 & -3.5 & 0.5 & 303 & 45.7 & 18.2 & -6.8 \\
\hline Uruguay & 103 & 11.5 & 21.8 & 10.8 & 101 & 7.7 & 1.1 & 1.0 & 101 & 3.6 & 20.5 & 9.6 \\
\hline $\begin{array}{l}\text { Central America } \\
\text { and the Caribbean }\end{array}$ & 143 & 7.9 & 13.2 & 12.2 & 118 & 4.1 & 2.6 & 1.7 & 122 & 3.6 & 10.4 & 10.3 \\
\hline Costa Rica & 160 & 14.3 & -5.5 & 29.9 & 112 & 8.2 & 5.6 & 1.0 & 143 & 5.6 & -10.5 & 28.6 \\
\hline El Salvador & 160 & 8.3 & 9.7 & 10.9 & 139 & -15.7 & 5.4 & 0.5 & 115 & 28.4 & 4.0 & 10.3 \\
\hline Guatemala & 142 & -3.8 & 17.2 & 25.2 & 104 & 7.7 & 0.8 & 2.0 & 136 & -10.7 & 16.2 & 22.7 \\
\hline Haiti & 64 & -4.6 & 21.5 & -31.7 & 110 & 5.9 & -2.8 & 2.0 & 58 & -9.9 & 25.0 & -33.1 \\
\hline Honduras & 94 & 4.2 & -0.7 & 4.2 & 96 & 4.9 & -6.2 & 2.0 & 98 & -0.7 & 5.9 & 2.2 \\
\hline Nicaragua & 91 & 4.1 & 20.8 & 6.1 & 100 & 5.0 & 6.6 & 1.5 & 91 & -0.9 & 13.3 & 4.5 \\
\hline Panama & 173 & 23.3 & 31.0 & 4.2 & 131 & 2.1 & 2.4 & 2.0 & 133 & 20.8 & 27.9 & 2.1 \\
\hline Dominican Republic & 137 & -8.7 & -3.6 & 20.3 & 113 & 5.0 & -0.3 & 2.0 & 121 & 13.1 & -3.3 & 18.0 \\
\hline
\end{tabular}

Source: ECLAC.

${ }^{a}$ Preliminary estimates. 
Table 12

LATIN AMERICA AND THE CARIBBEAN: TERMS OF

TRADE (GOODS), FOB/FOB

(Indexes: $1980=100$ and growth rates)

\begin{tabular}{|c|c|c|c|c|c|c|c|c|c|c|}
\hline & \multicolumn{4}{|c|}{ Indexes } & \multicolumn{5}{|c|}{ Growth rates } & \multirow{2}{*}{$\begin{array}{c}\begin{array}{c}\text { Cumulative } \\
\text { variation }\end{array} \\
1981-1992^{\mathrm{a}}\end{array}$} \\
\hline & 1989 & 1990 & 1991 & $1992^{\mathrm{a}}$ & 1988 & 1989 & 1990 & 1991 & $1992^{\mathrm{a}}$ & \\
\hline $\begin{array}{l}\text { Latin America and } \\
\text { the Caribbean }\end{array}$ & 79 & 79 & 74 & 72 & -0.3 & 1.3 & -0.4 & -5.6 & -3.4 & -28.3 \\
\hline $\begin{array}{l}\text { Oil-exporting } \\
\text { countries }\end{array}$ & 69 & 74 & 64 & 62 & -12.6 & 7.8 & 6.8 & -13.6 & -3.9 & -38.5 \\
\hline Bolivia & 82 & 80 & 64 & 58 & -11.3 & 0.4 & -2.6 & -19.3 & -9.7 & -41.9 \\
\hline Colombia & 88 & 82 & 78 & 73 & -0.7 & -4.3 & -6.5 & -5.4 & -5.5 & -26.7 \\
\hline Ecuador & 63 & 69 & 61 & 58 & -15.2 & 3.8 & 9.1 & -11.4 & -4.5 & -42.0 \\
\hline Mexico & 67 & 72 & 63 & 62 & -13.3 & 5.9 & 7.0 & -11.9 & -1.4 & -37.8 \\
\hline Peru & 95 & 82 & 74 & 72 & 16.5 & -5.0 & -13.2 & -9.5 & -3.0 & -27.9 \\
\hline Venezuela & 64 & 78 & 62 & 57 & -18.4 & 20.0 & 21.0 & -20.9 & -7.8 & -43.3 \\
\hline $\begin{array}{l}\text { Non-oil-exporting } \\
\text { countries }\end{array}$ & 88 & 83 & 86 & 84 & 10.0 & $\mathbf{- 3 . 1}$ & -5.8 & 3.5 & -2.7 & -16.3 \\
\hline South America & 89 & 83 & 87 & 85 & 11.2 & -4.0 & -6.1 & 4.5 & -2.0 & -14.9 \\
\hline Argentina & 68 & 68 & 67 & 68 & 5.3 & 2.1 & 0.0 & -1.2 & 0.6 & -32.0 \\
\hline Brazil & 89 & 84 & 92 & 90 & 11.1 & -8.2 & -5.7 & 9.4 & -2.1 & -10.2 \\
\hline Chile & 95 & 86 & 87 & 84 & 21.0 & -4.0 & -9.3 & 1.7 & -3.9 & -16.0 \\
\hline Paraguay & 133 & 130 & 133 & 121 & 5.9 & 5.5 & -2.5 & 2.5 & -8.6 & 21.8 \\
\hline Uruguay & 114 & 102 & 100 & 98 & 6.6 & 0.4 & -10.6 & -2.0 & -1.5 & -2.0 \\
\hline $\begin{array}{l}\text { Central America } \\
\text { and the Caribbean }\end{array}$ & 96 & 91 & 91 & 86 & 3.3 & -0.5 & -5.2 & 0.9 & -6.4 & -14.5 \\
\hline Costa Rica & 84 & 73 & 73 & 69 & 0.3 & -4.8 & -12.3 & -0.8 & -5.9 & -31.5 \\
\hline El Salvador & 66 & 57 & 55 & 51 & 7.6 & -13.3 & -14.6 & -3.5 & -7.4 & -49.5 \\
\hline Guatemala & 94 & 85 & 82 & 77 & 2.4 & 1.7 & -9.9 & -3.3 & -5.7 & -22.9 \\
\hline Haiti & 90 & 82 & 86 & 78 & -8.1 & -9.0 & -8.4 & 4.5 & -10.0 & -22.5 \\
\hline Honduras & 104 & 95 & 102 & 91 & 18.3 & 2.5 & -7.8 & 6.6 & -10.8 & -9.3 \\
\hline Nicaragua & 107 & 99 & 90 & 75 & 0.9 & 4.3 & -7.5 & -9.1 & -15.8 & -24.7 \\
\hline Panama & 114 & 125 & 124 & 119 & -0.7 & 2.7 & 10.1 & -1.4 & -3.5 & 19.3 \\
\hline Dominican Republic & 93 & 76 & 73 & 68 & 13.4 & 5.0 & -18.7 & -3.4 & -7.4 & -32.3 \\
\hline
\end{tabular}

Source: ECLAC.

a Preliminary estimates. 
Table 13

LATIN AMERICA: PRICES OF MAIN EXPORT COMMODITIES

(Dollars at current prices and rates of variation)

\begin{tabular}{|c|c|c|c|c|c|c|c|c|c|c|}
\hline & \multicolumn{5}{|c|}{ Average annual prices } & \multicolumn{4}{|c|}{ Annual rates of variation } & \multirow{2}{*}{$\begin{array}{c}\text { Cumulative } \\
\text { variation }\end{array}$} \\
\hline & 1980 & 1985 & 1990 & 1991 & $1992^{\mathrm{a}}$ & 1989 & 1990 & 1991 & $1992^{b}$ & \\
\hline Unrefined sugar $c$ & 28.7 & 4.1 & 12.6 & 9.0 & 9.3 & 25.5 & -1.6 & -28.8 & 3.1 & -67.8 \\
\hline Bananas $^{c}$ & 18.9 & 18.4 & 29.5 & 25.0 & 22.5 & -17.0 & 44.6 & -15.3 & -10.1 & 19.0 \\
\hline $\operatorname{Cocoa}^{c}$ & 118.1 & 102.3 & 57.7 & 54.2 & 50.4 & -21.6 & 2.1 & -6.1 & -7.0 & -57.3 \\
\hline Coffee (mild) ${ }^{c}$ & 178.8 & 145.6 & 89.2 & 85.0 & 63.1 & -20.8 & -16.6 & -4.7 & -25.8 & -64.7 \\
\hline Beef $^{c}$ & 125.9 & 97.7 & 115.4 & 120.8 & 110.2 & 2.0 & -0.9 & 4.7 & -8.8 & -12.5 \\
\hline Fish meal $^{d}$ & 504.0 & 280.0 & 412.0 & 478.0 & 492.0 & -25.0 & 1.0 & 16.0 & 2.9 & -2.4 \\
\hline Maize $^{d}$ & 210.3 & 135.3 & 119.9 & 140.1 & 135.6 & 3.8 & -14.8 & 16.8 & -3.2 & -35.5 \\
\hline Soya beans ${ }^{d}$ & 296.0 & 225.0 & 247.0 & 240.0 & 239.0 & -9.5 & -10.2 & -2.8 & -0.4 & -19.3 \\
\hline Wheat ${ }^{d}$ & 177.4 & 138.0 & 137.0 & 129.0 & 154.0 & 16.4 & -19.4 & -5.8 & 19.4 & -13.2 \\
\hline Cotton $^{c}$ & 94.2 & 61.7 & 82.1 & 74.6 & 62.8 & 19.7 & 8.2 & -9.2 & -15.8 & -33.3 \\
\hline Wool ${ }^{c}$ & 194.5 & 141.0 & 155.0 & 119.2 & 125.4 & -7.7 & -19.1 & -23.1 & 5.2 & -35.5 \\
\hline Copper $^{c}$ & 98.6 & 64.4 & 120.9 & 106.3 & 104.2 & 9.5 & -6.4 & -12.1 & -1.9 & 5.7 \\
\hline $\operatorname{Tin}^{\tau}$ & 7.6 & 5.4 & 2.8 & 2.5 & 2.8 & 19.4 & -29.8 & -10.6 & 11.6 & -63.7 \\
\hline Iron ore ${ }^{d}$ & 28.1 & 26.6 & 30.8 & 33.3 & 35.4 & 13.0 & 16.0 & 8.0 & 6.4 & 25.8 \\
\hline Lead ${ }^{\mathrm{c}}$ & 41.1 & 17.8 & 36.8 & 25.4 & 25.1 & 2.7 & 20.8 & -31.2 & -0.9 & -38.8 \\
\hline \multirow{2}{*}{\multicolumn{11}{|c|}{ Crude petroleum ${ }^{\mathrm{f}}$}} \\
\hline & & & & & & & & & & \\
\hline IMF average & 35.5 & 27.0 & 22.0 & 18.3 & $18.3^{g}$ & 21.1 & 27.9 & -16.8 & 0.1 & -48.4 \\
\hline Colombia & $\ldots$ & $\ldots$ & 22.5 & 19.2 & $18.7^{\mathrm{g}}$ & $\ldots$ & 23.0 & -14.9 & -2.3 & $\ldots$ \\
\hline Ecuador & 34.9 & 26.6 & 22.2 & 18.6 & $18.2^{\mathrm{g}}$ & $17 \ddot{1}$ & 24.7 & -16.2 & -2.2 & $-47 . \ddot{8}$ \\
\hline Mexico & 30.0 & 24.1 & 17.6 & 13.1 & $13.0^{h}$ & 17.8 & 15.8 & -25.7 & -0.5 & -56.7 \\
\hline Venezuela & 27.6 & 25.9 & 16.9 & 14.2 & $14.8^{g}$ & 27.6 & 7.6 & -15.8 & 4.0 & -46.4 \\
\hline
\end{tabular}

Source: UNCTAD, Monthly Commodity Price Bulletin, , supplement 1970-1989 (TD/B/C.1/CPB/L.101/Add.1), November 1989; and vol. XII No. 9 (TD/B/C.1/CPB/L.135), September 1992; International Monetary Fund, International Financial Statistics, November 1992; Pctroleum Market Intelligence Weekly, various issues; EClAC, on the basis of official data.

Note: Unrefined sugar, FOB, Caribbean ports, for exports to the free market. Bananas from Central America, CIF, North Sea ports. Cocoa beans, average of daily prices (futures), New York/London. Coffee, mild arabica, ex-dock New York. Beef, frozen and deboned, all sources, United States ports. Fish meal all sources, 64-65\% proteins, CIF Hamburg. Maize, Argentina, CIF, North Sea ports. Soya beans, United States, No. 2, yellow bulk, CIF Rotterdam. Wheat, FOB United States, No. 2, Hard Red Winter. Cotton, Mexican M 1-3/32", CIF Northern Europe. Wool clean, combed, grade 48"s, United Kingdom. Copper, tin, lead and zinc, spot cash prices on the London Metal Exchange. Iron ore, Brazil to Europe, C 64.5\% Fe, FOB. Petroleum, IMF average, average of spot prices of "Dubai", "Brent" (United Kingdom) and "Alaskan N. Slope" petroleum, which reflects relatively even consumption of medium, light and heavy crude throughout the world; Colombia, C. Limón 30 (United States Gulf Coast); Ecuador, Oriente-30 (United States Gulf Coast); Mexico, Maya Heavy-22 (United States Gulf Coast); Venezuela, Tía Juana-22 (Caribbean).

a January-August average. ${ }^{b}$ January-August average as compared to average for $1991 . \quad{ }^{c}$ United States cents per pound.

${ }^{\mathrm{d}}$ Dollars per metric ton. $\quad{ }^{\mathrm{e}}$ Dollars per pound. ${ }^{\mathrm{f}}$ Dollars per barrel. ${ }_{\mathrm{B}}$ January-October average. ${ }_{\mathrm{h}}^{\mathrm{h}}$ January-September average. 
Table 14

LATIN AMERICA AND THE CARIBBEAN: PURCHASING POWER

OF EXPORTS OF GOODS

(Indexes: $1980=100$ and growth rates)

\begin{tabular}{|c|c|c|c|c|c|c|c|c|c|}
\hline \multicolumn{4}{|c|}{ Indexes } & \multicolumn{5}{|c|}{ Growth rates } & \multirow{2}{*}{$\begin{array}{c}\begin{array}{c}\text { Cumulative } \\
\text { variation }\end{array} \\
1981-1992^{2}\end{array}$} \\
\hline 1989 & 1990 & 1991 & $1992^{\mathrm{a}}$ & 1988 & 1989 & 1990 & 1991 & $1992^{\mathrm{a}}$ & \\
\hline
\end{tabular}

Latin America and the Caribbean

$\begin{array}{llllllllll}122 & 128 & 127 & 131 & 8.1 & 4.5 & 5.3 & -1.0 & 3.0 & 31.5\end{array}$

Oil-exporting

countries

Bolivia

Colombia

Ecuador

Mexico

Peru

Venezuela

104120

$69 \quad 80$

$145 \quad 162$

$101 \quad 115$

$146 \quad 163$

$85 \quad 70$

127

131

8.1

112
67
169
113
157
65
74

108
54
156
117
157
65
68

-7.3
2.4
-10.3
1.3
-7.3
-1.8
-8.9

$\begin{array}{rr}12.2 & 15.6 \\ 21.2 & 16.9 \\ 7.1 & 11.9 \\ 2.6 & 14.1 \\ 7.1 & 11.8 \\ 21.1 & -18.0 \\ 24.5 & 33.2\end{array}$

$-7.2$

-16.3
4.7

4.7
-2.0

-2.0
-3.6

-3.6
-6.6

$-17.7$

$-3.1 \quad 8.1$

$-20.0 \quad-46.3$

$-7.6 \quad 56.3$

$3.6 \quad 16.8$

$0.0 \quad 57.4$

$-0.8 \quad-35.3$

Non-oil-exporting countries

$142 \quad 140 \quad 145$

$157 \quad 18.9$

South America

Argentina

Brazil

Chile

Paraguay

Uruguay

$156 \quad 150$

$99 \quad 132$

$171 \quad 149$

$172 \quad 165$

362403

$161 \quad 158$

158

128

160

179

383

148

17326.0

$\begin{array}{ll}135 & 31.8 \\ 180 & 24.9\end{array}$

$$
\begin{aligned}
& 198 \\
& 331
\end{aligned}
$$

27.2

$\begin{array}{ll}153 & 37.1 \\ 153 & 15.3\end{array}$

$\begin{array}{rrrrr}\mathbf{- 0 . 1} & \mathbf{- 1 . 6} & \mathbf{5 . 0} & \mathbf{8 . 3} & \mathbf{5 7 . 1} \\ & & & & \\ \mathbf{- 1 . 5} & -\mathbf{3 . 6} & \mathbf{4 . 8} & \mathbf{9 . 8} & \mathbf{7 2 . 9} \\ \mathbf{- 1 . 0} & \mathbf{3 3 . 9} & -2.9 & 5.6 & \mathbf{3 5 . 3} \\ -\mathbf{5 . 1} & -12.7 & \mathbf{7 . 6} & 12.6 & 80.3 \\ 7.7 & -4.4 & \mathbf{8 . 8} & 10.4 & 98.0 \\ \mathbf{4 4 . 3} & 11.1 & -\mathbf{5 . 0} & -13.6 & 230.5 \\ \mathbf{6 . 7} & -1.7 & -6.6 & 3.6 & 53.2\end{array}$

Central America

and the Caribbean

Costa Rica

El Salvador

Guatemala

Haiti

Honduras

Nicaragua

Panama

$\begin{array}{rr}\mathbf{8 5} & \mathbf{8 8} \\ 131 & 123 \\ 30 & 40 \\ 75 & 75 \\ 61 & 62 \\ 104 & 95 \\ 76 & 76 \\ 95 & 115\end{array}$

94
128
39
75
66
96
58
141

\begin{tabular}{rrrrrrr}
95 & $-\mathbf{0 . 2}$ & $\mathbf{4 . 8}$ & $\mathbf{2 . 9}$ & $\mathbf{6 . 8}$ & $\mathbf{1 . 0}$ & $\mathbf{- 5 . 2}$ \\
151 & 4.3 & 8.4 & -6.0 & 4.4 & 17.5 & 50.6 \\
38 & -4.0 & -31.6 & 36.3 & -4.2 & -1.0 & -61.9 \\
79 & 5.0 & 7.8 & 0.1 & 0.4 & 4.3 & -21.3 \\
37 & -15.1 & -20.1 & 3.1 & 5.0 & -42.8 & -63.2 \\
104 & 13.5 & 5.7 & -8.6 & 1.3 & 7.4 & 3.5 \\
50 & -21.2 & 45.3 & -0.9 & -23.1 & -13.6 & -49.6 \\
138 & -11.8 & 8.9 & 20.8 & 22.6 & -2.4 & 37.8 \\
52 & 23.3 & -1.1 & -24.0 & -10.5 & -12.0 & -48.1 \\
\hline
\end{tabular}

Source: ECLAC.

areliminary estimates. 
Table 15

LATIN AMERICA AND THE CARIBBEAN: TRACE BALANCE (GOODS) (Millions of dollars)

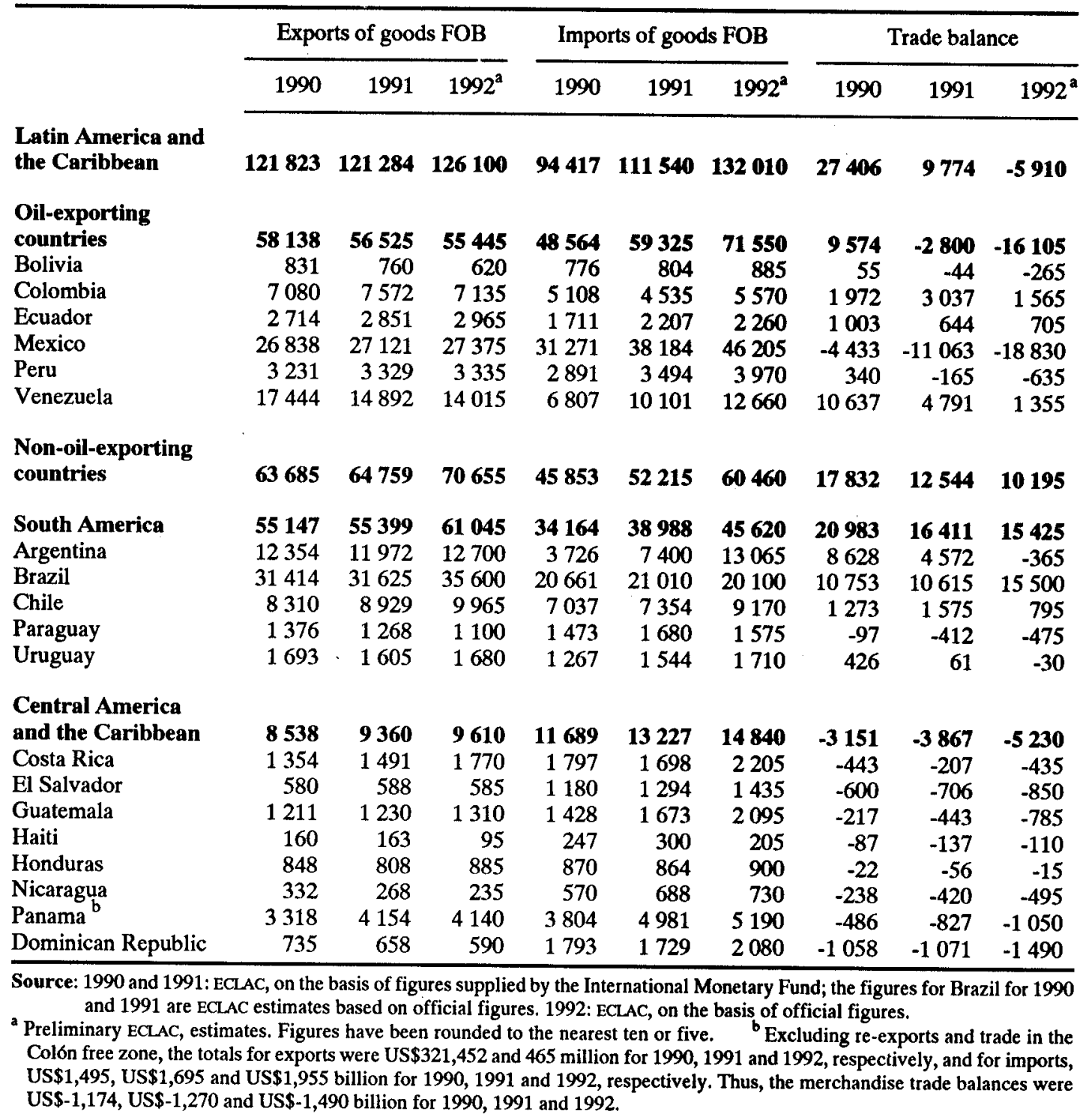




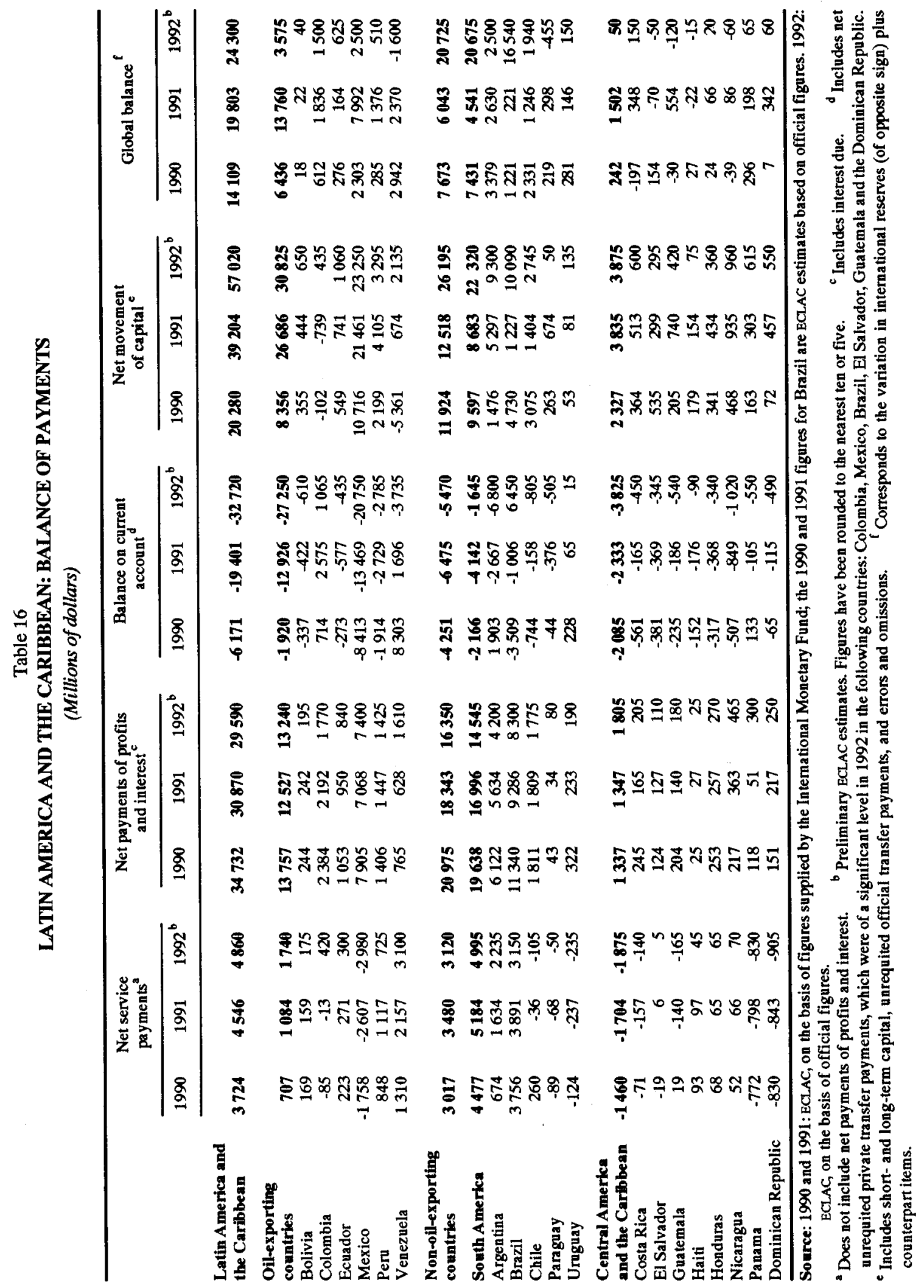


Table 17

LATIN AMERICA AND THE CARIBBEAN: NET CAPTTAL INFLOW AND TRANSFER OF RESOURCES

(Billions of dollars and percentages)

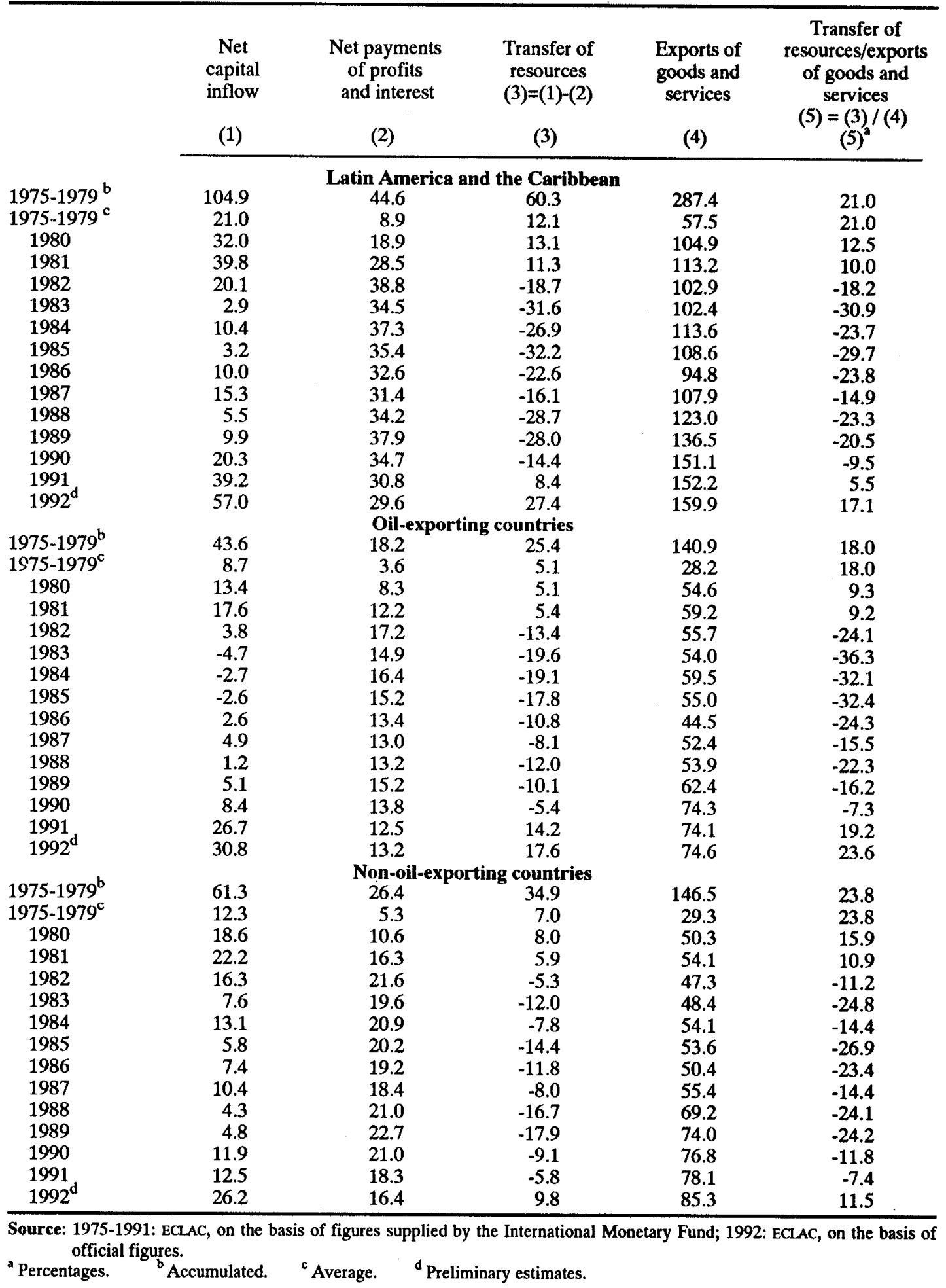


Table 18

LATIN AMERICA AND THE CARIBBEAN: INDEXES OF

STOCK-EXCHANGE PRICES IN DOLLARS

(Annual percentage variations) $^{2}$

\begin{tabular}{|c|c|c|c|c|c|c|c|c|c|c|c|}
\hline & 1982 & 1983 & 1984 & 1985 & 1986 & 1987 & 1988 & 1989 & 1990 & 1991 & $1992^{b}$ \\
\hline Argentina & -62 & 45 & -19 & 75 & -27 & 7 & 30 & 136 & -38 & 392 & -34 \\
\hline Brazil & -26 & 31 & 41 & 81 & -27 & -66 & 104 & 39 & -68 & 152 & -2 \\
\hline Colombia & $\ldots$ & $\ldots$ & $\ldots$ & -25 & 121 & 62 & -18 & 6 & 27 & 174 & 38 \\
\hline Chile & -57 & -34 & -28 & 36 & 134 & 18 & 22 & 35 & 31 & 90 & 19 \\
\hline Mexico & -79 & 85 & -2 & 8 & 81 & -11 & 98 & 67 & 25 & 100 & 7 \\
\hline Venezuela & $\ldots$ & $\ldots$ & $\ldots$ & -30 & 54 & 45 & -27 & -35 & 572 & 34 & -38 \\
\hline
\end{tabular}

Source: ECLAC, on the basis of figures provided by the International Finance Corporation (IFC).

End of year. ${ }^{\text {a }}$ October 1992 in relation to December 1991. 


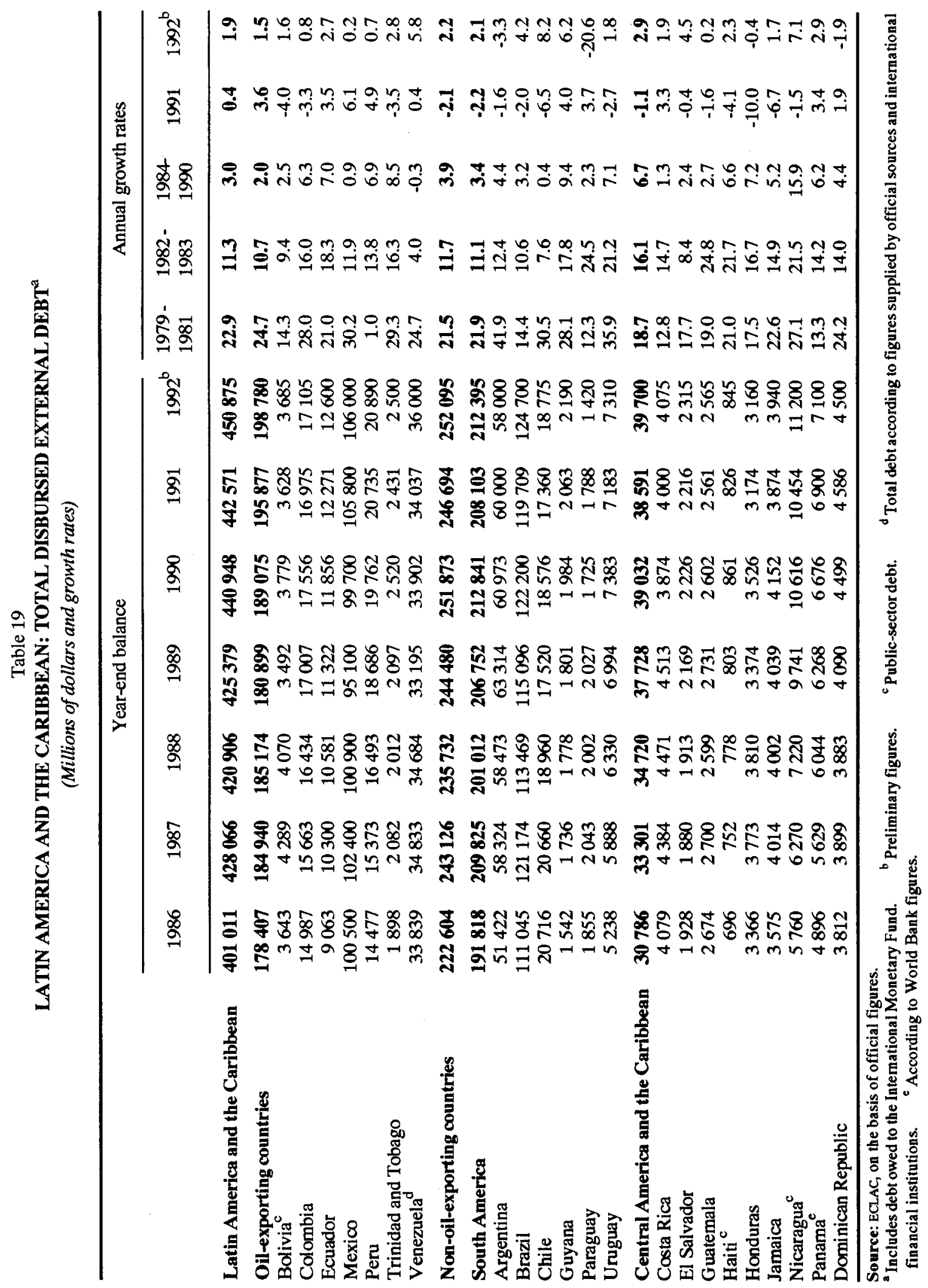


Table 20

LATIN AMERICA AND THE CARIBBEAN: TOTAL INTEREST DUE AS A PERCENTAGE OF EXPORTS OF GOODS AND SERVICES

(Percentages)

\begin{tabular}{|c|c|c|c|c|c|c|c|c|c|c|c|}
\hline & $\begin{array}{l}1979- \\
1981\end{array}$ & $\begin{array}{l}1982- \\
1983\end{array}$ & 1984 & 1985 & 1986 & 1987 & 1988 & 1989 & 1990 & 1991 & $1992^{a}$ \\
\hline $\begin{array}{l}\text { Latin America and } \\
\text { the Caribbean }\end{array}$ & 23.7 & 38.7 & 36.7 & 36.1 & 36.6 & 30.4 & 29.0 & 28.6 & 25.3 & 22.6 & 19.6 \\
\hline $\begin{array}{l}\text { Oil-exporting } \\
\text { countries }\end{array}$ & 20.3 & 33.1 & 33.0 & 32.6 & 33.9 & 27.8 & 29.1 & 27.5 & 22.5 & 20.2 & 19.3 \\
\hline Bolivia & 26.4 & 41.6 & 49.8 & 46.8 & 42.1 & 38.4 & 41.0 & 30.2 & 25.0 & 26.8 & 24.2 \\
\hline Colombia & 14.3 & 26.3 & 22.8 & 28.9 & 20.5 & 20.5 & 20.7 & 21.7 & 18.7 & 16.0 & 15.9 \\
\hline Ecuador & 18.4 & 29.6 & 33.3 & 25.7 & 29.7 & 32.5 & 33.5 & 33.7 & 29.3 & 25.0 & 20.7 \\
\hline Mexico & 31.8 & 42.5 & 39.2 & 37.2 & 38.3 & 29.7 & 29.9 & 28.3 & 24.0 & 20.8 & 19.2 \\
\hline Peru & 19.3 & 27.3 & 34.8 & 31.3 & 31.7 & 29.1 & 33.6 & 29.9 & 35.3 & 36.6 & 32.3 \\
\hline Venezuela & 9.5 & 21.3 & 23.9 & 26.4 & 34.2 & 25.9 & 29.0 & 26.6 & 17.0 & 15.6 & 17.6 \\
\hline $\begin{array}{l}\text { Non-oil-exporting } \\
\text { countries }\end{array}$ & 27.4 & 45.5 & 40.9 & 40.0 & 39.2 & 32.9 & 28.9 & 29.5 & 28.1 & 25.0 & 19.8 \\
\hline South America & 30.1 & 49.3 & 44.0 & 42.7 & 42.3 & 34.9 & 30.2 & 31.0 & 29.8 & 26.2 & 20.5 \\
\hline Argentina & 24.1 & 56.1 & 57.6 & 51.1 & 50.9 & 50.9 & 42.0 & 51.2 & 38.9 & 36.9 & 27.3 \\
\hline Brazil & 35.9 & 50.1 & 39.6 & 40.0 & 42.4 & 33.1 & 29.4 & 29.2 & 30.9 & 27.2 & 21.6 \\
\hline Chile & 24.7 & 44.2 & 50.1 & 46.4 & 37.1 & 26.4 & 21.3 & 18.5 & 17.8 & 14.6 & 11.1 \\
\hline Paraguay & 13.1 & 15.3 & 13.7 & 17.3 & 15.4 & 21.0 & 12.5 & 6.9 & 5.3 & 5.3 & 6.6 \\
\hline Uruguay & 11.2 & 23.5 & 34.8 & 34.2 & 24.7 & 24.1 & 23.5 & 27.6 & 27.2 & 21.7 & 16.9 \\
\hline $\begin{array}{l}\text { Central America } \\
\text { and the Caribbean }\end{array}$ & 12.5 & 20.8 & 19.8 & 20.3 & 20.4 & 19.8 & 18.8 & 17.2 & 14.8 & 15.3 & 14.7 \\
\hline Costa Rica & 19.7 & 34.6 & 26.6 & 24.9 & 21.8 & 21.3 & 22.0 & 23.6 & 15.4 & 9.9 & 7.9 \\
\hline El Salvador & 6.4 & 12.0 & 12.3 & 11.1 & 10.1 & 10.9 & 9.5 & 8.8 & 13.0 & 12.3 & 11.4 \\
\hline Guatemala & 5.3 & 8.3 & 12.3 & 14.9 & 17.4 & 13.6 & 13.9 & 11.3 & 11.2 & 6.9 & 6.4 \\
\hline Haiti & 2.6 & 2.4 & 5.2 & 5.4 & 5.1 & 6.0 & 8.2 & 9.5 & 8.7 & 9.6 & 13.3 \\
\hline Honduras & 11.2 & 19.3 & 15.9 & 16.1 & 19.5 & 18.5 & 18.0 & 18.5 & 18.9 & 20.5 & 19.8 \\
\hline Nicaragua & 22.8 & 42.7 & 57.9 & 78.3 & 88.5 & 75.6 & 96.7 & 62.1 & 58.3 & 110.4 & 122.4 \\
\hline Dominican & & & & & & & & & & & \\
\hline Republic & 18.0 & 23.6 & 18.0 & 18.7 & 18.9 & 20.3 & 14.7 & 11.6 & 8.1 & 11.8 & 12.3 \\
\hline
\end{tabular}

Source: ECLAC, on the basis of official figures.

${ }^{a}$ Preliminary estimates. 
Table 21

LATIN AMERICA AND THE CARIBBEAN: TO'TAL DISBURSED EXTERNAL DEBT AS A PERCENTAGE OF EXPORTS OF GOODS AND SERVICES ${ }^{\mathrm{a}}$

(Percentages)

\begin{tabular}{|c|c|c|c|c|c|c|c|c|c|c|c|}
\hline & $\begin{array}{l}1979- \\
1981\end{array}$ & $\begin{array}{l}1982- \\
1983\end{array}$ & 1984 & 1985 & 1986 & 1987 & 1988 & 1989 & 1990 & 1991 & $1992^{b}$ \\
\hline $\begin{array}{l}\text { Latin America and } \\
\text { the Caribbean }\end{array}$ & 236 & 338 & 329 & 355 & 427 & 398 & 341 & 310 & 290 & 290 & 282 \\
\hline $\begin{array}{l}\text { Oil-exporting } \\
\text { countries }\end{array}$ & 205 & 258 & 281 & 312 & 397 & 348 & 340 & 287 & 251 & 259 & 263 \\
\hline Bolivia & 241 & 338 & 329 & 458 & 547 & 660 & 607 & 403 & 387 & 394 & 469 \\
\hline Colombia & 146 & 265 & 239 & 314 & 233 & 230 & 244 & 233 & 200 & 182 & 195 \\
\hline Ecuador & 158 & 237 & 261 & 246 & 345 & 421 & 400 & 394 & 364 & 360 & 355 \\
\hline Mexico & 267 & 341 & 322 & 357 & 459 & 371 & 347 & 289 & 260 & 260 & 252 \\
\hline Peru & 234 & 306 & 349 & 362 & 429 & 428 & 447 & 418 & 476 & 497 & 499 \\
\hline Venezuela & 153 & 200 & 202 & 225 & 357 & 305 & 314 & 237 & 180 & 209 & 235 \\
\hline $\begin{array}{l}\text { Non-oil-exporting } \\
\text { countries }\end{array}$ & 271 & 403 & 385 & 403 & 455 & 449 & 342 & 331 & 330 & 321 & 299 \\
\hline South America & 293 & 423 & 397 & 411 & 475 & 463 & 342 & 329 & 329 & 320 & 296 \\
\hline Argentina & 274 & 480 & 481 & 491 & 610 & 717 & 525 & 538 & 412 & 425 & 382 \\
\hline Brazil & 330 & 419 & 363 & 379 & 460 & 431 & 315 & 307 & 347 & 342 & 317 \\
\hline Chile & 227 & 380 & 456 & 454 & 396 & 327 & 229 & 182 & 180 & 155 & 150 \\
\hline Paraguay & 156 & 372 & 289 & 287 & 244 & 265 & 182 & 124 & 92 & 94 & 86 \\
\hline Uruguay & 157 & 213 & 362 & 391 & 349 & 369 & 354 & 350 & 346 & 333 & 325 \\
\hline $\begin{array}{l}\text { Central America } \\
\text { and the Caribbean }\end{array}$ & 154 & 275 & 301 & 341 & 339 & 355 & 339 & 354 & 351 & 334 & 323 \\
\hline Costa Rica & 205 & 299 & 308 & 339 & 292 & 302 & 276 & 245 & 196 & 184 & 161 \\
\hline El Salvador & 109 & 210 & 218 & 219 & 188 & 207 & 203 & 266 & 253 & 244 & 245 \\
\hline Guatemala & 73 & 163 & 203 & 232 & 229 & 238 & 205 & 192 & 166 & 148 & 137 \\
\hline Haiti & 120 & 170 & 190 & 178 & 238 & 235 & 283 & 339 & 353 & 330 & 563 \\
\hline Honduras & 160 & 265 & 282 & 336 & 334 & 393 & 380 & 333 & 360 & 334 & 305 \\
\hline Nicaragua & 341 & 733 & 947 & 1433 & 2005 & 1932 & 2644 & 2859 & 2707 & 3093 & 3394 \\
\hline Dominican & & & & & & & & & & & \\
\hline Republic & 162 & 263 & 258 & 281 & 269 & 249 & 205 & 197 & 224 & 232 & 222 \\
\hline
\end{tabular}

Source: ECLAC, on the basis of official figures.

a Calculated on the basis of the external debt figures given in table 19 and the corresponding data on exports of goods and non-factor services.

b Preliminary estimates. 
Table 22

LATIN AMERICA: PRICES OF EXTERNAL DEBT PAPER ON THE SECONDARY MARKET

(Percentages of nominal value)

\begin{tabular}{|c|c|c|c|c|c|c|c|c|c|}
\hline & \multicolumn{3}{|c|}{1990} & \multicolumn{3}{|c|}{1991} & \multicolumn{3}{|c|}{1992} \\
\hline & January & June & $\begin{array}{c}\text { De- } \\
\text { cem- } \\
\text { ber }\end{array}$ & January & June & $\begin{array}{l}\text { De- } \\
\text { cem- } \\
\text { ber }\end{array}$ & January & June & $\begin{array}{l}\text { No- } \\
\text { vem- } \\
\text { ber }\end{array}$ \\
\hline Argentina & 12 & 13 & 20 & 19 & 25 & 36 & 39 & 50 & 41 \\
\hline Bolivia & 11 & $\cdots$ & $\cdots$ & $\ldots$ & $\ldots$ & $\ldots$ & 13 & 12 & 16 \\
\hline Brazil & 25 & 24 & 25 & 23 & 33 & 30 & 32 & 37 & 29 \\
\hline Colombia & 60 & 64 & 63 & 64 & 73 & 81 & 75 & 75 & 76 \\
\hline Costa Rica & 18 & 36 & 34 & 34 & 46 & 50 & 51 & 58 & 61 \\
\hline Chile & 62 & 65 & 74 & 75 & 88 & 89 & 89 & 89 & 90 \\
\hline Ecuador & 14 & 16 & 20 & 20 & 22 & 22 & 24 & 32 & 27 \\
\hline Honduras & 21 & $\cdots$ & $\ldots$ & $\cdots$ & $\ldots$ & $\ldots$ & 26 & 27 & 35 \\
\hline Jamaica & 40 & 44 & $\ldots$ & $\cdots$ & $\cdots$ & $\ldots$ & 75 & 74 & 69 \\
\hline Mexico & 37 & 45 & 46 & 45 & 55 & 60 & 62 & 65 & 63 \\
\hline Nicaragua & 1 & $\ldots$ & $\cdots$ & $\ldots$ & $\cdots$ & $\cdots$ & 6 & 9 & 6 \\
\hline Panama & 19 & 12 & 13 & 11 & 13 & 21 & 24 & 33 & 31 \\
\hline Peru & 6 & 4 & 4 & 3 & 7 & 11 & 14 & 17 & 15 \\
\hline Dominican Republic & 13 & 17 & $\cdots$ & $\ldots$ & $\ldots$ & $\ldots$ & $\ldots$ & 33 & 30 \\
\hline Uruguay & 50 & 49 & 55 & $\ldots$ & $\ldots$ & $\ldots$ & 70 & 70 & 76 \\
\hline Venezuela & 35 & 46 & 50 & 50 & 60 & 66 & 67 & 61 & 60 \\
\hline Average $^{a}$ & 29.5 & 33.3 & 35.1 & 32.5 & 41.5 & 45.0 & 46.6 & 50.9 & 46.2 \\
\hline
\end{tabular}


Table 23

LATIN AMERICA AND THE CARIBBEAN: FIFTH ROUND OF EXTERNAL DEBT RENEGOTIATIONS WITH COMMERCLAL BANKS ${ }^{\text {a }}$

(1989/1992)

\section{ARGENTINA ${ }^{b}$}

Eligible debt:

US $\$ 23$ billion of principal

Terms of the fourth round of rescheduling:

US\$ 8.6 billion of interest arrears

- Interest rate: $0.81 \%$ over LIBOR

- Amortization period: 19 years

- Grace period: 7 years.

\section{CONVERSION OPTIONS FOR PRINCIPAL AND THEIR DISTRIBUTION}

\begin{tabular}{cc}
\hline Available options & $\begin{array}{c}\text { Distribution of eligible } \\
\text { principal (millions of dollars) }\end{array}$ \\
\hline
\end{tabular}

Terms and
conditions

8050

a) Discount bonds

b) Par bonds
14950
Discount: $35 \%$

Repayment period: 30 years

Grace: 30 years

Interest: $0.81 \%$ over LIBOR

Discount: 0\%

14950
Repayment period: 30 years

Grace: 30 years

Interest: First year: $\quad 4.0 \%$

Second year: $4.3 \%$

Third year: $\quad 5.0 \%$

Fourth year: $5.3 \%$

Fifth year: $5.5 \%$

Sixth year: $5.8 \%$

Years 7-30: $6 \%$
Face value of new claims (millions of dollars)

\section{TERMS FOR CONVERSION OF INTEREST ARREARS}

a) Payment of US\$400 million in cash

b) Conversion of US\$300 million into 4-6-year zero-coupon bonds

c) The balance of interest arrears is converted into 12-year bonds ( 3 years of grace) with an interest rate of $0.81 \%$ over LIBOR. 


\section{FINANCING OF AGREEMENT}

\section{Coverage}

a) Par and discount bonds: guarantee on $100 \%$ of the principal and

12 months of interest, renewable, through the purchase of United States

Treasury zero-coupon bonds and the creation of blocked deposits,

respectively.

b) The zero-coupon bonds related to the conversion of arrears are guaranteed by cash
Estimated cost

(millions of dollars)
Financing

(millions of dollars)

$\begin{array}{lr}\text { World Bank } & 750 \\ \text { IMF } & 1000 \\ \text { IDB } & 700 \\ \text { Government of Japan } & 800 \\ \text { Government of Argentina } & .\end{array}$

3600 
BRAZIL $^{\mathfrak{c}}$

Eligible bank debt:

US\$44 billion of principal

US\$3 billion of interest arrears ${ }^{d}$

Terms of the third round of rescheduling:

- In terest rate: $1.13 \%$ over LIBOR

- Amortization period: 12 years

- Grace period: 5 years

\section{CONVERSION OPTIONS AND THEIR DISTRIBUTION}

Distribution of

eliglble debt (millions of dollars)

\section{Avallable optlons}

Terms and conditlons

$\cdots$

a) Discount bonds

b) Par bonds

c) Bonds with transitory reduction of interest charges

d) Restructuring of principal via debt-for-bond exchanges, together with:

new lending equivalent to $18 \%$ of the converted principal

e) Rescheduling of principal, with transitory reduction of interest charges

Discount: 35\%

Repayment period: 30 years

Grace: 30 years

Interest: $0.81 \%$ over LIBOR

Discount: $0 \%$

Repayment period: 30 years

Grace: 30 years

Interest: First year: $\quad \mathbf{4 . 0} \%$

Second year: $4.3 \%$

Third year: $\quad 5.0 \%$

Fourth year: $5.3 \%$

Fifth year: $5.5 \%$

Sixth year: $5.8 \%$

Years 7-30: $6 \%$

Discount: 0\%

Repayment period: 15 years

Grace: 9 years

Interest: Years 1-2: $\quad 4.0 \%$

Years 3-4: $4.5 \%$

Years 5-6: $5.0 \%$

Discount: 0\%

Repayment period: 18 years

Grace: 10 years

Interest: $0.88 \%$ over LIBOR

... Repayment period: 15 years

Grace: 7 years

Interest: $0.88 \%$ over LIBOR

... Repayment period: 20 years

Grace: 10 years

Interest: $0.81 \%$ over LIBOR ;
Face value of new claims (millions of dollars)

Years 7-15: $\quad 0.81 \%$ over LIBOR

in years 1-6 the difference is

capitalized if the rate is

higher than the following:

Years 1-2: $\quad 4.0 \%$

Years 3-4: $\quad 4.5 \%$

Years 5-6: $\quad 5.0 \%$ 
(Table 23 (conclusion)

f) Bonds with fixed interest rate and temporary capitalization of interest

Discount: 0\%

Repayment period: 20 years

Grace: 10 years

Interest: $8 \%$; in years $1-6$

the difference between that

rate and the following is capi-

talized:

Years 1-2: $4.0 \%$

Years 3-4: $\quad 4.5 \%$

Years 5-6: $5.0 \%$

\section{TERMS OF CONVERSION OF INTEREST ARREARS ${ }^{f}$}

Arrears are consolidated into

12-year bonds ( 3 years of

grace) at an interest rate of

$0.81 \%$ over LIBOR

3. FINANCING OF THE AGREEMENT

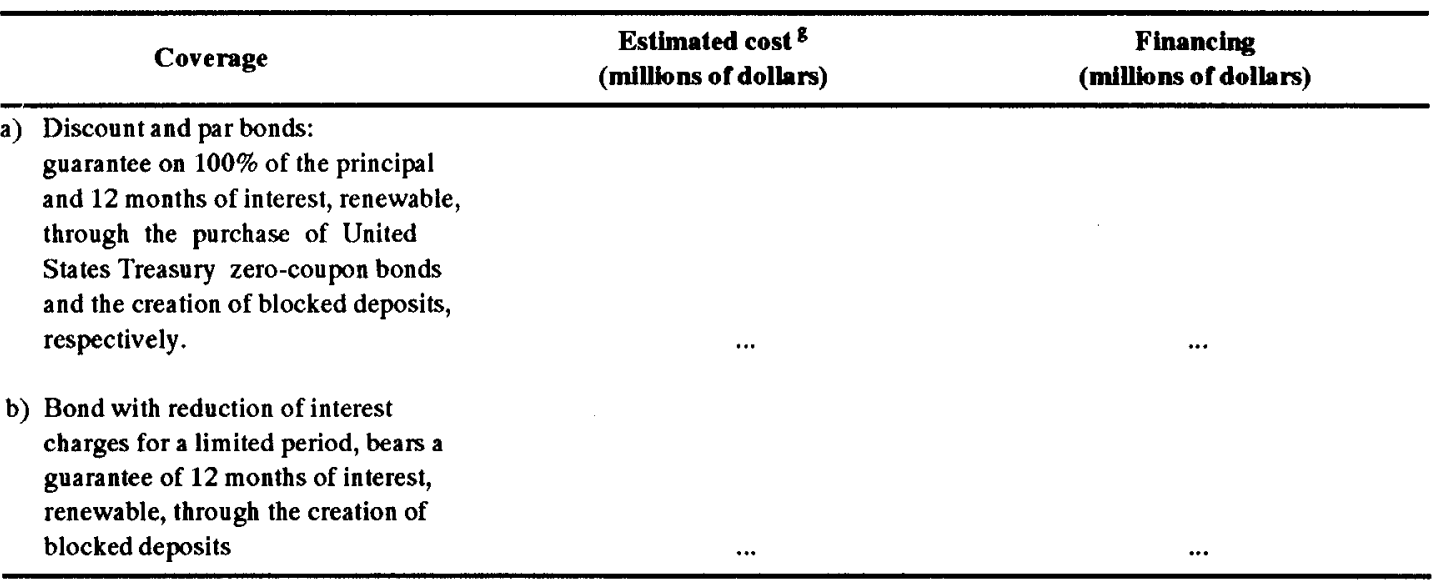

Source: BCLAC, on the basis of official figures.

"Before 1992 Brady-style agreements were made with Mexico, Venezuela, Costa Rica and Uruguay.

Agreement finalized in December 1992.

Agreement only in principle.

d Estimate. As a prior condition for a Brady-style agreement, the banks required the Govemment of Brazil to agree to eliminate interest arrears accrued between 1989-1990, totalling US\$9 billion. Thus, in 1991 it was agreed that Brazil would immediately pay the commercial banks US\$2 billion in cash on interest arrears, with the balance of US\$7 billion being converted into bonds as soon as the terms of a Brady-style agreement could be agreed to. Brazil issued those bonds in November 1992. The repayment period was seven years, with one year of grace. There are two options for the interest rate. The first is a rate of $8.38 \%$ in $1992 ; 8.75 \%$ in 1993 and $0.81 \%$ over LiBor until maturity. The second option is $0.81 \%$ over LIBOR, with a floor of $6 \%$ for $L J B O R$ until 1995 and a ceiling of $7.7 \%$ in 1992 , rising to $8.2 \%$ until 1995 .

- Brazil did not participate in the fourth round of rescheduling, having fallen into a partial moratorium.

' See noted.

The cost of guarantees cannot be determined until the banks formally choose between the available options. It is permissible to finance the guarantees in stages over a two-year period. 
Table 24

\section{LATIN AMERICA AND THE CARIBBEAN: FIFTH ROUND OF EXTERNAL DEBT RESCHEDULINGS WTTH THE PARIS CLUB}

(1989/1992)

\begin{tabular}{|c|c|c|c|c|c|c|c|}
\hline \multirow{2}{*}{ Country } & \multirow{2}{*}{ Date } & \multicolumn{2}{|c|}{$\begin{array}{l}\text { Restructured } \\
\text { maturities }\end{array}$} & \multicolumn{2}{|c|}{$\begin{array}{l}\text { Percentage of } \\
\text { service } \\
\text { restructured }\end{array}$} & \multicolumn{2}{|c|}{$\begin{array}{l}\text { Terms } \\
\text { (years) }\end{array}$} \\
\hline & & Months & $\begin{array}{l}\text { Amount } \\
\text { (millions } \\
\text { of dollars) }\end{array}$ & $\begin{array}{l}\text { Inte- } \\
\text { rest }\end{array}$ & Principal & $\begin{array}{l}\text { Repay- } \\
\text { ment } \\
\text { period }\end{array}$ & $\begin{array}{l}\text { Grace } \\
\text { period }\end{array}$ \\
\hline Trinidad and Tobago & January/1989 & 14 & 209 & - & 100 & 9.4 & 4.9 \\
\hline Guyana & May/1989 & 14 & 195 & 100 & 100 & 19.4 & 9.9 \\
\hline Costa Rica & May/1989 & 14 & 182 & 100 & 100 & 9.4 & 4.9 \\
\hline Mexico & May/1989 & 10 & 2400 & 100 & 100 & 9.6 & 6.1 \\
\hline Ecuador & October/1989 & 14 & 397 & 100 & 100 & 9.4 & 5.9 \\
\hline Argentina & December/1989 & 15 & 2450 & 100 & 100 & 9.3 & 5.8 \\
\hline Bolivia & March/1990 & 24 & 276 & 100 & 100 & \multicolumn{2}{|c|}{ Toronto terms } \\
\hline Jamaica & April/1990 & 18 & 179 & 100 & 100 & 9.3 & 4.8 \\
\hline Trinidad and Tobago & April/1990 & 13 & 110 & - & 100 & 9.5 & 5.0 \\
\hline Guyana & September $/ 1990$ & 35 & 123 & 100 & 100 & \multicolumn{2}{|c|}{ Toronto terms ${ }^{b}$} \\
\hline Honduras & September $/ 1990$ & 11 & 280 & 100 & 100 & $14.6^{\mathrm{c}}$ & 8.0 \\
\hline El Salvador & September $/ 1990$ & 13 & 143 & 100 & 100 & $14.4^{\mathrm{c}}$ & 7.9 \\
\hline Panama & November $/ 1990$ & 17 & 100 & 100 & 100 & 9.3 & 4.8 \\
\hline Jamaica & July/1991 & 13 & 97 & 100 & 100 & $14.5^{c}$ & 5.1 \\
\hline Costa Rica & July/1991 & 9 & 125 & 100 & 100 & 9.6 & 5.0 \\
\hline Peru & September/1991 & 14 & 5900 & $100^{d}$ & 100 & $14.5^{c}$ & 7.1 \\
\hline Argentina & September/1991 & 9 & 1700 & 100 & 100 & 10.0 & 6.0 \\
\hline Dominican Republic & November/1991 & 18 & 780 & 100 & 100 & $14.3^{c}$ & 6.1 \\
\hline Nicaragua $\mathrm{e}^{-}$ & December/1991 & 15 & 730 & $100^{e}$ & 100 & \multicolumn{2}{|c|}{ "Enhanced" Toronto terms $f$} \\
\hline Ecuador & January/1992 & 12 & 350 & 100 & 100 & $14.5^{\mathrm{c}}$ & 8.0 \\
\hline Bolivia & January/1992 & 18 & 216 & 100 & 100 & \multicolumn{2}{|c|}{ "Enhanced" Toronto terms ${ }^{f}$} \\
\hline Brazil & February/1992 & 20 & 11000 & 100 & 100 & 13.4 & 1.8 \\
\hline Argentina & July/1992 & 33 & $\ldots$ & 100 & 100 & 14.8 & 1.2 \\
\hline Honduras & October/1992 & 34 & $\ldots$ & 100 & 100 & \multicolumn{2}{|c|}{ "Enhanced" Toronto terms $f$} \\
\hline
\end{tabular}

Source: 1989: ECLAC, on the basis of official figures; 1990 to 1992: UNCTAD, Money, Financing and Development Division.

a Interest rates are renegotiated bilaterally. $\mathrm{b}$ Under an agreement reached among creditor countries at the Toronto summit meeting of June 1988, special terms and conditions are to be granted to low-income developing countries. In these cases, the creditor country may choose among three options: i) forgiveness of one third of the debt subject to restructuring and the rescheduling of the remainder over a 14-year period with eight years of grace; ii) the rescheduling of the restructurable debt over a 25 -year period with 14 years of grace; and iii) the reduction of the interest rate by 3.5 points or $50 \%$, whichever is less, and the rescheduling of the debt over a 14-year period with eight years of grace. For further information see UNCTAD, Trade and Development Report, 1989, Geneva, 1989, United Nations publication, Sales No. S.89.II.D.14. c The longer repayment periods are a reflection of what are known as the "Houston terms" for lower middle-income countries, which were agreed upon at the Houston summit meeting in 1990 . The terms include rescheduling the principal with a longer than traditional maturity: 20 years for concessional debt and 15 years for non-concessional debt. Creditors also have the option of participating in debt conversions or swaps for $100 \%$ of concessional debt and $10 \%$ or US $\$ 10$ million, whichever is higher, of non-concessional debt.

${ }^{d}$ Late interest accounts for $70 \%$ of this. ${ }^{e}$ Late interest accocunts for $50 \%$ of this. 'The new terms grant three options: i) a $50 \%$ debt reduction, with the remaining debt being rescheduled over a period of 23 years (including six years of grace); ii) a reduction of the interest rate that provides relief equivalent to that of the first option in terms of present value, and a rescheduling of obligations with a repayment period of 23 years (no grace period); and iii) a rescheduling at 23 years (six years of grace) with an interest rate below market rates and interest payment capitalization with no charge during the grace period. For concessional debt, the maturities of the consolidation period are rescheduled with an amortization period of 30 years and a grace period of 22 years. 